\title{
Role Of SKeletal Muscle TRANSPORT SYSTEMS IN STATIN-INDUCED MYOTOXICITY
}

\author{
Dissertation \\ zur \\ Erlangung der naturwissenschaftlichen Doktorwürde \\ (Dr. sc. nat.) \\ vorgelegt der \\ Mathematisch-naturwissenschaftlichen Fakultät \\ der \\ Universität Zürich \\ von \\ Christian Feuerstacke \\ aus \\ Deutschland \\ Promotionskomitee \\ Prof. Dr. Raimund Dutzler (Vorsitz) \\ Prof. Dr. Bruno Stieger (Leitung der Dissertation) \\ Prof. Dr. Michael Arand
}

Zürich 2015 



\title{
Curriculum Vitae
}

\author{
Surname: $\quad$ FEUERSTACKE \\ First name: Christian \\ Nationality: $\quad$ German \\ Date of birth: $\quad$ 05.04.1984 \\ Place of birth: $\quad$ Ebersdorf (Thuringia, Germany)
}

PhD candidate (biochemistry) at University Zurich

$10 / 2010-09 / 2014$

Department of Clinical Pharmacology and Toxicology, University Hospital Zurich, Switzerland

Title of thesis: "Role of Skeletal Muscle Transport Systems in Statin-induced Myotoxicity"

Academic Achievements, Honors and Conferences

- Received grant from PhD-program "Predictive Toxicology" to participate in advanced training "Fachtoxikologe DGPT"

- Poster presentation at BioMedical Transporter Conference 2013, St. Moritz, Switzerland

- Poster presentation at EUROTOX Conference 2013, Interlaken, Switzerland

- 2013 Young Scientist Award at EUROTOX 2013, Interlaken, Switzerland

- Poster presentation at Day of clinical Research 2012 \& 2014, UniSpital Zürich

- Poster presentation at Pharma/Tox Poster Day 2012, Universität Zürich

- Short Oral Presentation at Annual XeRR Meeting 2012 \& 2014, Zurich, Switzerland

- Mentoring master students

- Teaching practical course at UZH

\section{Certified skilled courses from UZH}

- Project Management for Advanced Researchers

- Career Cornerstone - Active Career Building in Academia and Business

- Wirtschafts Know How

- Leadership skills for doctoral candidates

Diplom Ingenieur in Pharma-Biotechnologie

$10 / 2005-02 / 2010$

University of Applied Science, Jena, Germany

Title: "Setup and improve a method to produce inside-out membrane vesicles from baculovirus infected insect cells containing an ABC-transport protein"

\section{Studying Bioinformatics}

$10 / 2003-07 / 2005$

Friedrich-Schiller University, Jena , Germany

Military service (Deutsche Bundeswehr)

$10 / 2002-06 / 2003$

Hannover \& Erfurt 



\section{PhD thesis}

\section{Role of Skeletal Muscle Transport SYSTEMS IN STATIN-INDUCED MYOTOXICITY}

\section{Christian Feuerstacke}

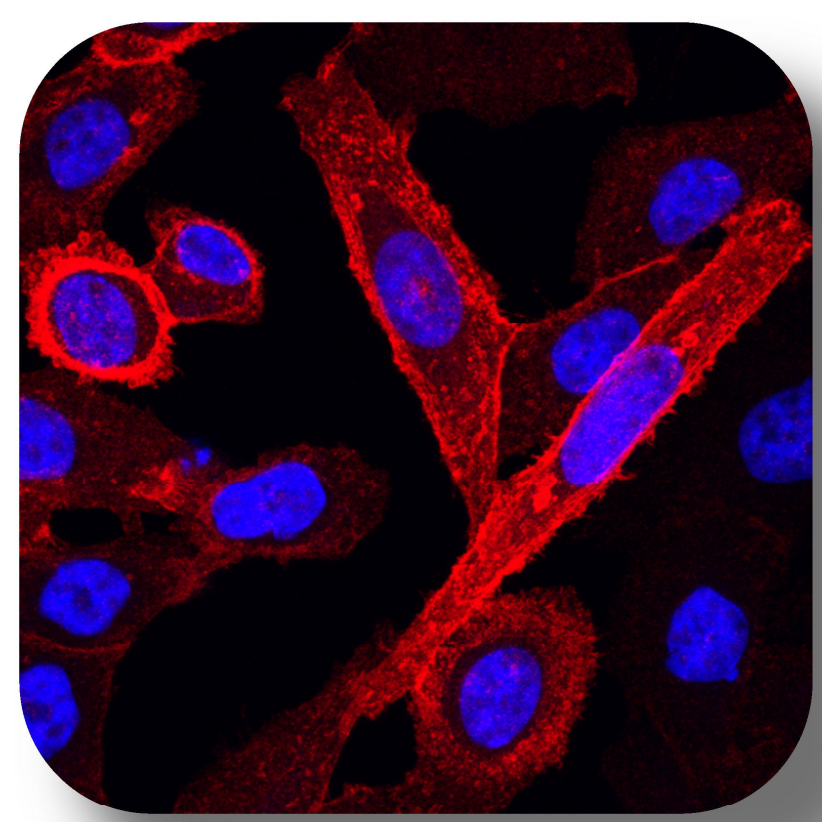

March 2015

\footnotetext{
This work was carried out in the laboratory of Prof. Bruno Stieger Clinical Pharmacology and Toxicology University Hospital Zurich
} 



\section{TABLE OF CONTENTS}

ABSTRACT vii

ZUSAMMENFASSUNG ix

ABBREVIATIONS $\quad$ xi

1 INTRODUCTION 1

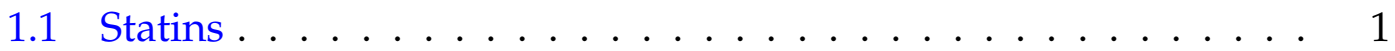

1.1.1 Statin-induced myopathies and rhabdomyolysis . . . . . 3

1.1.2 Patient related risk factors . . . . . . . . . . . 3

1.1.3 Statin related risk factors . . . . . . . . . . . . . 4

1.1.4 Role of comedications in statin-induced myopathies . . . 5

1.1.5 Putative molecular mechanisms of statin toxicity . . . . 6

1.1.6 Molecular targets of adverse statin effects . . . . . . . . 9

1.2 Transport proteins . . . . . . . . . . . . . . 10

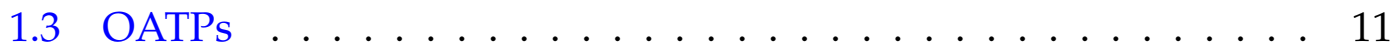

1.3.1 Nomenclature . . . . . . . . . . . . . . . . . 11

1.3.2 Substrate specificity . . . . . . . . . . . 12

1.3.3 Structure ..................... 13

1.3.4 The hepatocellular OATPs 1B1 and 1B3 . . . . . . . . . 14

1.4 Cell systems to study statin toxicity . . . . . . . . . . . . . . . 14

1.5 Aims of the presented work . . . . . . . . . . . 16

2 MATERials AND METHODS $\quad \mathbf{1 7}$ 


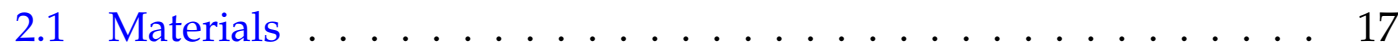

2.2 Methods . . . . . . . . . . . . . . . . . . . 18

2.2 .1 Cell culture . . . . . . . . . . . . . . . . . . . . . . 18

2.2.2 Differentiation of myoblast into myotubes . . . . . . . . 18

2.2 .3 Transfection . . . . . . . . . . . . . . . . . . . . . . 18

2.2.3.1 Killing curve . . . . . . . . . . . . . . . . 18

2.2.3.2 Preparation of the expression vector . . . . . . . 19

2.2.3.3 Chemical transfection . . . . . . . . . . . . . . 20

2.2.3.4 Physical transfection . . . . . . . . . . . . . . 21

2.2.3.5 Limiting dilution cloning $\ldots \ldots \ldots . . \ldots 22$

2.2.4 qRT-PCR using TaqMan ${ }^{\circledR}$-based gene expression analysis 22

2.2.5 Preparation of total membrane fraction . . . . . . . . 23

2.2.6 Western blotting . . . . . . . . . . . . . . 23

2.2.7 Transport assay using radiolabeled or fluorescent substrates 24

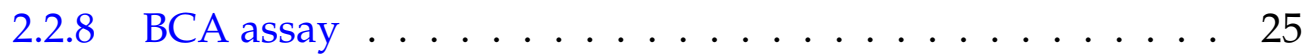

2.2 .9 Cell viability assay $\ldots \ldots \ldots \ldots \ldots$

2.2.10 Confocal laser scanning microscopy (CLSM) . . . . . . 26

2.2.11 Apoptosis assessed by measuring caspase-3 activity . . . . 27

3 Results 29

3.1 Statin toxicity in non-muscle cell lines . . . . . . . . . . . . . . 29

3.2 Statin toxicity in non-muscle cell lines compared to muscle cells . 30

3.3 Transfection of L6 and C2C12 cells . . . . . . . . . . . . . . . 32

3.3 .1 Killing curve . . . . . . . . . . . . . . . . . . . . 32

3.3.2 Transfection with OATP1B1 and OATP1B3 in pIRESneo2 vector . . . . . . . . . . . . . . . . 32

3.4 Uptake of statins . . . . . . . . . . . . . . . . . . . 37

3.5 Statin toxicity $\ldots \ldots \ldots \ldots \ldots \ldots \ldots \ldots \ldots$

3.5.1 Impact of OATP inhibition on statin toxicity . . . . . . . . 41 
3.6 Investigations to study the expression of OATP1B1 in transfected C2C12 cells . . . . . . . . . . . . . . . . . . 43

3.6.1 Subcellular localization of OATP1B1 in C2C12 cells . . . . 44

3.6.2 Western blot analysis of C2C12 1B1 cells . . . . . . . . . 44

3.6.3 qRT-PCR using TaqMan ${ }^{\circledR}$ based gene expression analysis to detect OATP1B1 RNA . . . . . . . . . . . . . . 45

3.7 Rat L6 cells transfected with OATP1B1 or -1B3 . . . . . . . . . . 46

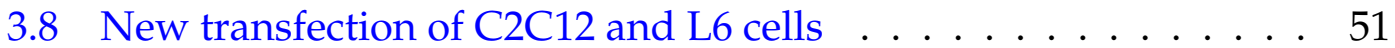

3.8.1 Recloning of OATP1B1 and OATP1B3 cDNA from pIRESneo2 into pcDNA3.1+ . . . . . . . . . . . . . . 51

3.8.2 Transfection of muscle cells using pcDNA3.1+ vector . . . 51

3.8.3 qRT-PCR using TaqMan ${ }^{\circledR}$ based gene expression analysis to detect OATP1B1 and -1B3 RNA . . . . . . . . . . . 53

3.8.4 Functional screening using the transport assay . . . . . . 54

3.8.5 Western blot analysis of C2C12 cells expressing OATP1B1 56

3.9 Statin toxicity using the C2C12 1B1 Cl.2 cells . . . . . . . . . . 58

3.10 Statin-induced apoptosis in C2C12 cells . . . . . . . . . . . . . 59

4 Discussion $\quad 63$

$\begin{array}{ll}\text { ACKNOWLEDGEMENTS } & \mathbf{7 1}\end{array}$

$\begin{array}{ll}\text { Publications AND AWARDS } & \mathbf{7 3}\end{array}$

$\begin{array}{lr}\text { REFERENCES } & \mathbf{7 5}\end{array}$ 



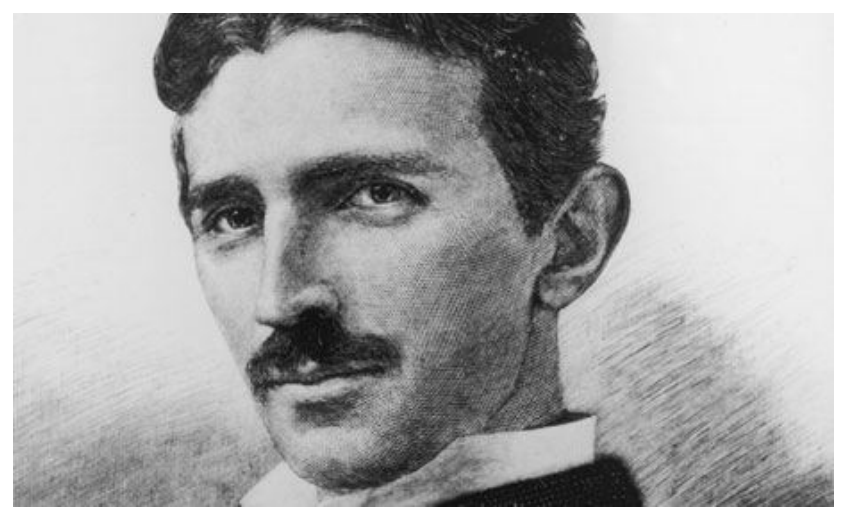

Let the future tell the truth, and evaluate each one according to his work and accomplishments. The present is theirs; the future, for which I have really worked, is mine.

Nikola Tesla 



\section{ABSTRACT}

Statins are a class of drugs used to treat hypercholesterolemia and to prevent cardiovascular diseases. They belong to the so called HMG-CoA reductase inhibitors and inhibit cholesterol synthesis. By inhibiting an early step in cholesterol synthesis, statins prevent neoformation of cholesterol in the liver and thus reduce LDL cholesterol levels. The most adverse effects reported are musclerelated adverse events and are generally described as myopathies. Myopathy is a muscular disease, affecting skeletal muscles by destroying its structural integrity. The symptoms range from muscle weakness on to muscle cramps to the point of disintegration of the striated skeletal muscle cells. This worst case is termed as rhabdomyolyse and can lead to death if symptoms are not recognized. Because statins can damage and destroy muscle cells, statins are defined as myotoxic. The exact mechanism how statins induce toxicity in muscle cells still needs to be clarified. It is currently not known to full detail whether cytotoxic effects originate at the plasma membrane or are initiated intracellularly. This thesis deals with these two hypotheses and examines the role of transport proteins in the statin-induced myotoxicity. Here the influence of the transport proteins OATP1B1 and OAT1B3 on the viability of muscle cells after statin treatment was investigated. These transporters are naturally expressed in hepatocytes and known to be responsible for statin uptake into liver cells. To identify the relevance of uptake transporters to the in vivo activity of statins, an in vitro tool was established, which allows studying the influence of uptake transporters on statin toxicity in muscle cells. Therefore, skeletal muscle cells from rat (L6) and mouse $(\mathrm{C} 2 \mathrm{C} 12)$ were transfected with the with the hepatocellular statin transporter OATP1B1 or OATP1B3. Clones were screened with a transport assay measuring the uptake of a model substrate into cells to identify a functionally active clone. The expression level of the transport proteins in the transfected cells was investigated at the RNA and protein level using qRT-PCR and confocal laser-scanning microscopy. Toxicity studies comparing wild type and transfected cells investigated the susceptibility towards statins. 
Here, cell viability was assessed after cells were treated with statins at increasing concentrations. These studies revealed no difference regarding statin toxicity comparing the two cell lines. Nevertheless, it was possible to demonstrate an increased susceptibility of muscle cells towards statins compared to the nonmuscle cell line $\mathrm{CHO}$. To assess statin-induced apoptosis, an assay was established measuring caspase- 3 activity after statin treatment. Here, it was possible to demonstrate that caspase- 3 activity is already induced after six hours. Caspase-3 activity in C2C12 OATP1B1 cells is increased in a statin concentration dependent manner. This effect was not observed in the wild type cells, clearly demonstrating that statin-induced myotoxicity is dependent upon a transmembrane transport mechanism. This thesis helped to better understand the mechanism of statin-induced myotoxicity. Further studies using human muscle cells could identify the exact transport proteins, responsible for statin uptake and thus could deliver an explanation why statins are toxic specifically for muscle cells and why other tissues types are not affected. 


\section{ZUSAMMENFASSUNG}

Statine zählen zu den am meisten verschriebenen Medikamenten in der westlichen Welt. Sie dienen dazu die Hypercholesterinämie zu behandeln und HerzKreislauf-Erkrankungen vorzubeugen. Statine gehören zu den Cholesterin-Synthese-Enzym-Hemmern vom Typ der HMG-CoA-Reduktase-Inhibitoren. Durch Inhibition eines frühen Schrittes in der Cholesterinsynthese führen sie zu einer Verminderung des LDL-Cholesterins, indem sie unter anderem dessen Neubildung in der Leber hemmen. Jedoch haben Statine Nebenwirkungen, die nicht zu vernachlässigen sind. Eine davon ist die Myopathie, welche die Skeletmuskulatur betrifft und hier zu funktionellen und strukturellen Veränderung führt. Die Symptome reichen von Muskelschwäche über Muskelkrämpfe bis hin zur Auflösung der quergestreiften Skelettmuskelzellen. Dieser schlimmst anzunehmende Fall wird als Rhabdomyolyse bezeichnet, welche bei einem unerkannt bleiben zum Tode führen kann. Da Statine die Muskelzellen schädigen und zerstören werden sie als myotoxisch bezeichnet. Der genaue Mechanismus der Statin-induzierten Moypathie ist bislang nicht vollständig aufgeklärt. So ist bisweilen unklar ob die Toxizität an der Zellmembran ausgelöst wird und durch eine Signalkaskade in das Zellinnere weitergeleitet wird oder ob Statine ein intrazelluläres Ziel haben nachdem sie in die Zelle aufgenommen wurden, welches das Absterben der Muskelzelle verursacht. Diese Doktorarbeit beschäftigt sich mit diesen beiden Hypothesen und untersucht die Rolle von Transportproteinen in der Statin-induzierten Myotoxizität. Dabei wurde untersucht welchen Einfluss die Transporter OATP1B1 und OATP1B3 auf die Viabilität von Muskelzellen haben, nachdem diese mit Statinen behandelt wurden. Diese Transporter sind natürlicherweise in Hepatozyten zu finden und sind erwiesenermaßen für die Aufnahme von Statinen in die Leberzelle verantwortlich. Für diese Untersuchungen wurden ein in-vitro-Tool generiert und anschliesend Toxizitätsstudien durchgeführt. Dafür wurden die Myoblastenzelllinien von Ratte (L6) und Maus (C2C12) jeweils mit den humanen Transportern OATP1B1 oder 
OATP1B3 transfiziert. Um einen Klon zu finden der funktionell aktiv ist wurden diese mit einem zellbasierten Transportexperiment gescreent, bei dem die Aufnahme eines Modellsubstrats in das Zellinere gemessen wurde. Zusätzlich wurde das Expressionsniveau der Transportproteine mittels quantitativer realtime PCR bestimmt. Nachdem ein funktionaler Klon gefunden werden konnte, wurde dieser mittels Western Blot Technologie und konfokaler Laser-ScanningMikroskopie charakterisiert. In den Toxizitätstudien wurde untersucht, ob die transfizierten Zellen empfindlicher gegenüber Statinen sind. Dazu wurden die Zellen mit Statinen über ein breites Konzentrationsspektrum behandelt und anschließend die Zellviabilität bestimmt. Bei diesen Studien konnte kein Unterschied zwischen den beiden Zelllinien hinsichtlich der Toxizität von Statinen festgestellt werden. Es konnte aber nachgewiesen werden, dass Muskelzellen empfindlicher gegenüber Statinen sind, als die Fibroblastenzelllinie CHO. Daraufhin wurde ein Versuchsaufbau etabliert der mittels Caspase-3-Aktivität die Induktion von Apoptose durch Statine messen kann. Hier zeigte sich bereits nach einer Statinbehandlung von sechs Stunden, dass in OATP1B1 exprimierenden Zellen mit zunehmender Statinkonzentration eine steigende Caspase3-Aktivität zu messen war. Diese Konzentrationsabhängigkeit konnte in den Wildtypzellen nicht nachgewiesen werden. Dieser Versuch zeigte deutlich, dass die Statin-induzierte Mytoxizität von einem transmembranären Transportmechanismus abhängt. Mit dieser Arbeit wurde dazu beigetragen, den Mechanismus der Statin-induzierten Myotxizität besser zu verstehen. Weitere Untersuchungen an humanen Muskelzellen könnten den genauen Transporter identifizieren, der für die Aufnahme von Statinen verantwortlich ist und somit eine Erklärung liefern warum Statine spezifisch für Muskelzellen toxisch sind und warum andere Gewebetypen nicht betroffen sind. 


\section{AbBreviations}

\begin{tabular}{|c|c|}
\hline $\mathrm{ABC}$ & ATP-binding cassette \\
\hline BSA & Bovine serum albumin \\
\hline BSP & Bromosulphophthalein \\
\hline CLSM & Confocal laser scanning microscopy \\
\hline $\mathrm{CHO}$ & Chinese hamster ovary (cell line) \\
\hline DAPI & 4'-6-diamidino-2-phenylindole \\
\hline DHEAS & Dehydroepiandrosterone sulfate \\
\hline DMEM & Dulbecco's modified Eagle's medium \\
\hline E3S & Estrone-3-sulfate \\
\hline $\mathrm{E} 17 \beta \mathrm{G}$ & Estradiol-17 $\beta$-glucuronide \\
\hline F-PP & Farnesyl pyrophosphate \\
\hline FCS & Fetal calf serum \\
\hline FDB & Flexor digitorum brevis \\
\hline G-PP & Geranyl pyrophosphate \\
\hline GG-PP & Geranyl geranyl pyrophosphate \\
\hline HEPES & 4-(2-hydroxyethyl)-1-piperazineethanesulfonic acid \\
\hline ICG & Indocyanine green \\
\hline LB & Lysogeny broth \\
\hline $\mathrm{NaB}$ & Sodium butyrate \\
\hline OAT & Organic anion transporter \\
\hline OATP & Organic anion transporting polypeptide \\
\hline ORF & Open reading frame \\
\hline $\mathrm{PAH}$ & p-Aminohippuric acid \\
\hline PBS & Phosphate buffered saline \\
\hline PCR & Polymerase chain reaction \\
\hline Pen/Strep & Mixture of penicillin and streptomycin \\
\hline PMSF & Phenyl methyl sulfonyl fluoride \\
\hline
\end{tabular}


S.D. Standard deviation

SDS Sodium dodecyl sulfate

SLC Solute carrier

SLCO Solute carrier organic anion (gene name for Oatps/OATPs) wt Wild type 




\section{INTRODUCTION}

\subsection{Statins}

3-hydroxy-3-methylglutaryl-coenzyme A (HMG-CoA) reductase inhibitors, or statins, are a class of drugs used for the treatment of hypercholesterolemia. Statins lower serum cholesterol levels and thereby significantly reduce the risk of cardiovascular events [1]. HMG-CoA reductase inhibitors act at the rate limiting step of the cholesterol synthesis by competitively inhibiting the enzyme HMG-CoA reductase and thus reducing the mevalonate production rate, which is the next molecule in the cholesterol synthesis cascade. During cholesterol synthesis a broad range of products in addition to cholesterol are generated, such as coenzyme Q10, dolichol and heme A [2], which have an essential role in cell physiology and maintenance of proper cell function.

All statins currently on the market possess a HMG-like moiety with an open lactone ring (i.e. mevalonate), except of simvastatin and lovastatin, which have a closed lactone ring. The closed ring structure is transformed into the biologically active form with an open ring in the body by hydrolysis. Newer statins are administered as the open acid forms and have a higher affinity for HMGCoA reductase and consequently possess higher potency of inhibition. This high affinity for HMG-CoA is shown by enzyme activity assays, where inhibition constants $(\mathrm{Ki})$ are between $5-45 \mathrm{nM}$ while the Michaelis constant $(\mathrm{Km})$ of HMG-CoA is $4 \mu \mathrm{M}$, explaining the potent inhibition of this enzyme by statins including simvastatin, pravastatin, fluvastatin, cerivastatin, atorvastatin and rosuvastatin [3-5].

The pathway of cholesterol synthesis is presented in Fig. 1. The reaction catalyzed by HMG-CoA reductase is the rate-limiting step of cholesterol biosynthesis. HMG-CoA reductase is subject to feedback-inhibition by cholesterol. 
Hence, inhibiting this enzyme reduces cholesterol levels. To maintain the intracellular cholesterol level, LDL-receptors are transcriptionally up regulated, which in turn leads to a decreased level of serum cholesterol. The consequently increased uptake of extracellular cholesterol into hepatocytes does interestingly not lead to higher cholesterol levels in the liver cells. Reason for this is the liver specific cholesterol hydroxylase (CYP7A1), which catalyzes the first step in the biosynthesis of bile acids. This process of cholesterol degradation in the liver leads to an overall reduction of cholesterol in the whole body. As more than $50 \%$ of total body cholesterol is endogenously produced, with the major site of synthesis being the liver, the target organ of statins is the liver [6].

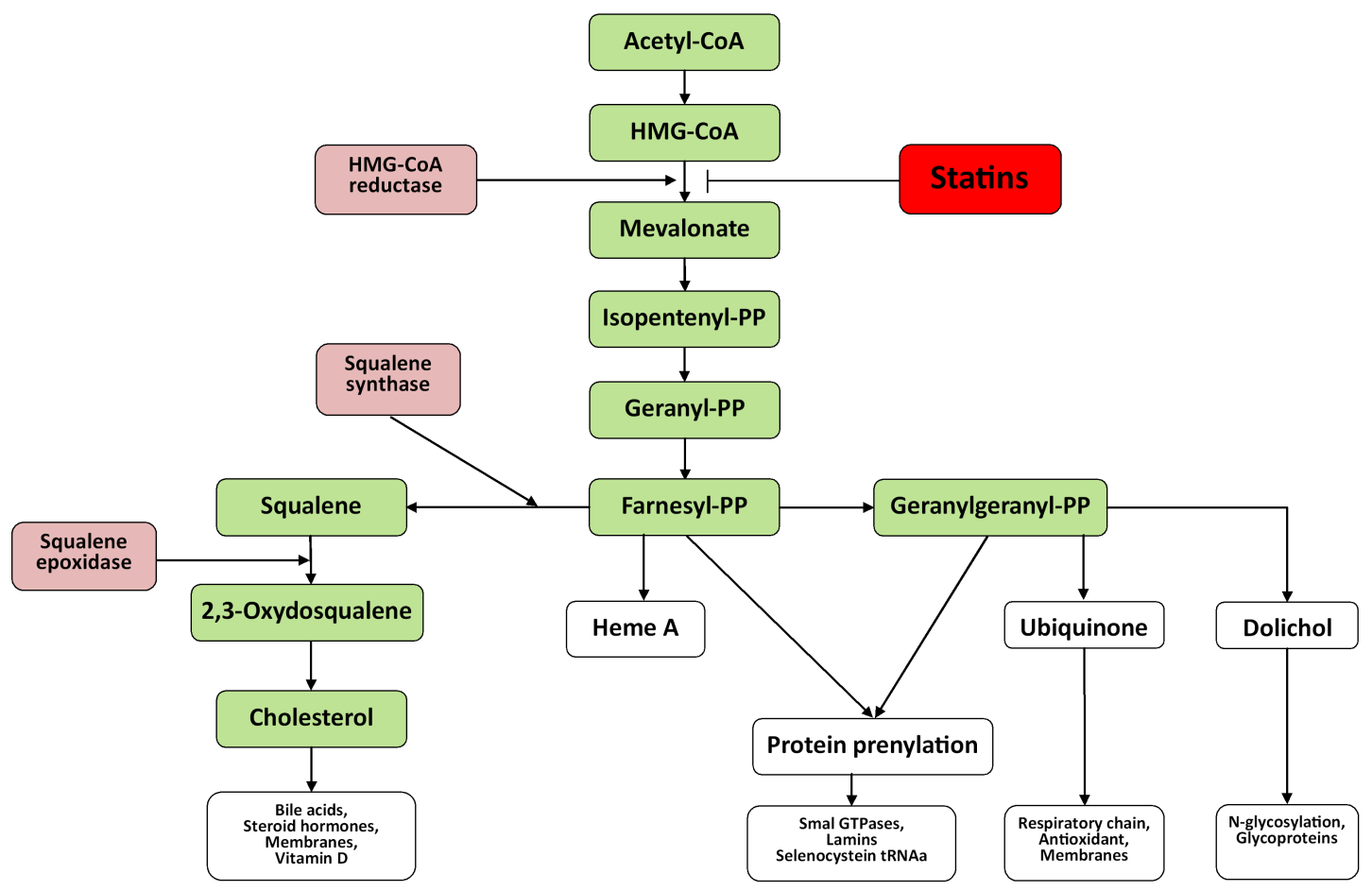

Fig. 1: Pathway of cholesterol biosynthesis.

HMG-CoA reductase converts HMG-CoA to mevalonate. Inhibition of this enzyme leads not only to reduced cholesterol levels, but also inhibits intermediate products like farnesyl pyrophosphate and geranylgeranyl pyrophosphate which are crucial to modify the functions of some small GTPases (adapted from [7, 8]). 


\subsubsection{Statin-induced myopathies and rhabdomyolysis}

Although statins belong to the best selling drugs dispensed by prescription in the US [9] and have an advantageous safety profile [10], they show some side effects which cannot be neglected. The most adverse effects reported are musclerelated adverse events (AEs) and are generally described as myopathies in the clinics [11]. The most common type of statin-induced myopathies is myalgia, which leads to muscle pain, fatigue, and weakness without elevated creatine kinase (CK) levels. AEs characterized by muscle symptoms with increased CK levels less than 10 times the upper limit of normal (ULN) are denoted as myositis. A serious, but rare AE under statin treatment is rhabdomyolysis (rhabdo: rod-like structures, myo: muscle, and lysis: dissolution) with an incident of 3.4 per 100,000 patient years [11]. Rhabdomyolysis is associated with muscle symptoms, elevated CK levels $>10$ times ULN and with creatinine elevation which involves usually brown urine and urinary myoglobin [12]. Rhabdomyolysis is the rapid breakdown of skeletal muscle tissue that leads to a release of breakdown products like myoglobin into the blood stream. Normally, myoglobin is loosely bound to plasma globulins and only small amounts are filtered in the kidney. When massive amounts of myoglobin are released, the binding capacity of the plasma protein is exceeded and myoglobin is then filtered by the glomeruli and reaches the tubules of the kidney. In the tubules myoglobin can form solid aggregates, called urinary casts, which reduce the flow of fluid and finally block the tubules. Additionally, the heme-bound iron can be released and generate reactive oxygen species damaging kidney cells. These processes lead to destruction of renal tubular cells, which reduces the glomerular filtration rate and finally lead to dysfunction of the kidney termed as kidney failure. To develop rhabdomyolysis patients have to be on statin for about one year in average, but there are cases reported where patients develop rhabdomyolysis already after only a few months depending on patients risk factors and further medications [13].

\subsubsection{Patient related risk factors}

Certain precipitating factors and predisposing conditions are known to increase the chance to develop rhabdomyolysis under statin treatment such as increased age, female gender, renal insufficiency, hepatic dysfunction, hypothyroidism, 
and several metabolic muscle diseases [8, 14-16]. Most of them promote myopathy by altering the metabolism and increasing the bioavailability of statins leading to higher plasma levels. The cytochrome p450 (CYP) system is a group of enzymes distributed ubiquitously. Its members are monoxygenases and add often a functional group to poorly water soluble drugs. This allows conjugation of such drugs to hydrophilic groups, which results in a conversion to more water soluble metabolites to facilitate biliary or renal excretion. All statins except of pravastatin utilize the CYP system for metabolism and disposal. A genetic predisposition with decreased activity of CYP3A4 reduces intrahepatic statin metabolism and consequently results in higher plasma concentrations [17, 18]. Membrane transporters being responsible for uptake (e.g. OATPs) and excretion (e.g. multidrug resistance-associated protein 2 [MRP2]) of substances play an important role in drug disposition and are recognized as important determinants of the transmembrane passage of drugs, not only in the liver. In hepatocytes, OATPs mediate the uptake of statins from the sinusoidal blood plasma. A polymorphism in the SLCO1B1 gene (c.521T > C, p.Val174Ala) was found to be highly significantly associated with myotoxicity in patients on a high dose simvastatin regimen [19]. This OATP1B1 variant displays in vitro a reduced transport capacity [20] and consequently affects the pharmacokinetics of statins by increasing its area under the curve (AUC) and the maximum serum concentration $c_{\max }[21,22]$.

\subsubsection{Statin related risk factors}

The risk of developing myopathies is also depending on the statin itself. Hydrophilic statins like pravastatin and rosuvastatin have lower chance to enter non-hepatic tissues compared to lipophilic statins like lovastatin, simvastatin, fluvastatin, atorvastatin and cerivastatin and may therefore be theoretically less toxic to myocytes. Still, there is an ongoing debate whether different statins have distinct risks of inducing myotoxicity [22]. The lowest risk to develop AEs is associated with fluvastatin, while atorvastatin shows the highest risk identified by meta-analysis of 18 prospective randomized controlled trials; the risks for simvastatin, lovastatin and pravastatin were intermediate and comparable [23]. In 2001 the hydrophilic cerivastatin was withdrawn from the market because of 52 deaths linked to cerivastatin-induced rhabdomyolysis that lead to kidney failure. The risk was found to be higher among patients who received 
gemfibrozil concomitantly or the full dose of cerivastatin $(0.8 \mathrm{mg} /$ day). Rhabdomyolysis was 10 times more common for cerivastatin compared to the other five statins on the market at this time [24].

\subsubsection{Role of comedications in statin-induced myopathies}

The risk of developing myopathy during statin treatment is increased if patients are co-treated with certain other drugs like cyclosporine A, gemfibrozil and possibly some other fibrates which can reduce the time to develop rhabdomyolysis down to one month [14, 25]. As statins are substrates of the CYP isoenzyme system, a concomitant treatment with inhibitors of this enzyme (e.g. cyclosporine, the antidepressant nefazodone, macrolide antibiotics, or protease inhibitors to treat HIV) increases the risk of myopathy with statins [26]. By competitively inhibiting the CYP-system, the metabolism of statins is reduced, leading to increased plasma levels and greater risk of AEs. As pharmaceutical products are often substrates or inhibitors of transporters, a second possibility to influence to plasma concentrations is the transporter mediated drug-drug interaction. Co-administrated drugs can reduce hepatic uptake of statins by acting as competitive inhibitor with higher affinity for the active site of the relevant transporter [27]. Many drugs, e.g. cyclosporine or gemfibrozil have been identified to inhibit drug transporters like OATP1B1, and thereby markedly increase the plasma concentrations and exposure of statins [28].

Myopathy and rhabdomyolysis is restricted to skeletal muscle tissue, and cardiomyopathy has never been associated with statin treatment. Discontinuation of the therapy leads to recovery of patients with variable improvement. While one study showed consistent recovery of statin muscle AEs [29], Vladutiu et. al found that "...variable persistent symptoms occurred in $68 \%$ of patients despite cessation of [statin] therapy" [30]. Interestingly, myopathy can be prevented in a rat model by administering mevalonate, the product of the inhibited enzymatic reaction, supporting the concept that this toxicity is a direct result of cholesterol synthesis inhibition and not an off-target effect [25]. Krähenbühl et. al showed that even geranylgeraniol, which is produced further down in the cholesterol synthesis pathway, can prevent statin-induced cytotoxicity, when co-administrated with simvastatin using a C2C12 myotube model [31]. One the other hand, inhibition of squalene synthase and squalene epoxidase did 
not induce myotoxicity in primary cultures of rat myotubes [32, 33], and squalene itself cannot rescue from myotoxicity, when co-administrated with statins [31]. Both enzymes are part of the squalene branch at the distal end of cholesterol biosynthesis and catalyze metabolic steps uncoupled of isoprene synthesis. Taken together, myotoxicity is not directly induced by lower cholesterol levels, but due to the reduction of the availability of the isoprenoids geranylgeranyl pyrophosphate (GG-PP) and farnesyl pyrophosphate (F-PP), which are byproducts of the cholesterol synthesis pathway.

\subsubsection{Putative molecular mechanisms of statin toxicity}

The exact mechanism of statin-induced myotoxicity is not fully understood, despite 26 years after it was reported for the first time [34]. Several mechanisms are suggested for example perturbed N-linked glycosylation, impaired isoprenylation, disruption of selenoprotein synthesis, impaired function of skeletal muscle mitochondria, increased excitability of muscle cell membrane, and impaired calcium signaling [7, 35-37].

\section{Perturbed N-linked glycosylation}

$\mathrm{N}$-linked-glycosylation is a covalent modification that proteins undergo during and after translation. It is an integral component for proper trafficking and functioning of numerous proteins, especially for proteins localized in the plasma membrane such as receptors and transporters. Dolichols are polyprenols containing 16 to 22 isoprene units and mediate the N-linked glycosylation of nascent polypeptides by serving as carriers, as well as an anchor whereupon the core oligosaccharide unit for protein glycosylation is assembled. N-linkedglycosylation is dependent on the mevalonate pathway, since dolichols are derivatives of G-PP (Fig. 1). Reduced dolichol production by statins can impair glycosylation and can therefore culminate in decreased membrane expression of specific receptors or membrane associated glycoproteins such as dystroglycan which undergoes extensive post-translational modification. Dystroglycan facilitates communication between muscle cytoskeleton and extracellular matrix, which can be interrupted, when dystroglycan glycosylation is defective $[8,35$, 
38]. However, no study so far investigated the direct effect of statins on dystroglycan glycosylation.

Statins can also impair insulin-induced glucose uptake as a consequence of reduced expression of glycosylated insulin receptor and insulin-like growth factor-1 (IGF-1) receptor at the plasma membrane and accumulation of unglycosylated receptors in endoplasmic reticulum as shown in mouse C2C12 myoblasts [39]. Moreover, reduced IGF-1 signaling leads to induction of atrogin1 , which is a hallmark of muscle atrophy. Atrogin-1 is expressed in a tissuespecific manner and appears to be a critical component in the enhanced proteolysis leading to muscle atrophy in diverse diseases. A recent study used C2C12 myotubes and zebrafish to show that depletion of geranylgeranyl after lovastatin treatment results in atrogin-1 induction [40].

\section{Impaired isoprenylation}

Isoprenoids, also called terpenes, like geranylgeranyl-PP and F-PP are organic substances, composed of at least two isoprenes which have a characteristic five carbon structure. Modification of proteins by covalent addition of isoprenoids to conserved cysteine residues is called prenylation and promotes membrane interactions with several proteins like nuclear lamins, guanosine triphosphate (GTP)-binding proteins (G-proteins), the subunits of trimeric G-proteins or protein kinases. In addition prenylation plays a major role in several proteinprotein interactions [41]. Prenylated G-proteins such as Rab, Ras and Roh play crucial roles in signaling pathways controlling cell growth and differentiation, e.g. metabolic control of the cytoskeleton is also mainly depending on coordinated signaling through G-proteins [35]. One study showed that statin treatment of L6 myoblasts leads to induction of apoptosis initiated by depletion of membrane bound Ras [42]. Recent studies investigating the role of $R a b$ small GTPases showed that statin treatment of isolated rat skeletal myofibers lead to inactivation of Rabs and induced vacuolation of the myofibers, degeneration and swelling of organelles, and eventually apoptosis [43].

Lamins are important structural proteins interact with membrane-associated proteins from the inner nuclear membrane. They are involved in chromatin organization, gene expression, and play a major role during mitosis by breaking down and reforming the nuclear envelope. Several lamins need to undergo 
farnesylation [44]. Lovastatin was previously shown to inhibit iosprenylation of lamin A and prevented consequently the assembling process of lamin A into the inner nuclear membrane [45]. This could possibly lead to a fragile nucleus with a deranged nucleoskeleton unresistant to forces occurring during muscle contraction. Furthermore it was shown that transcription of genes activated by mechanical stress (e.g. Nf-kB) is impaired [46], leading to the assumption that defective lamin prenylation induced by statins may indeed underlie statinassociated myopathy.

\section{Selenoproteins}

Selenoproteine are proteins containing a selenocystein amino acid residue which is inserted by a specific tRNA during protein synthesis. Selenocystein (Sec) tRNA is encoded by UGA, which normally represents the stop codon. If the UGA containing area of the mRNA forms a stem-loop structure, the stop codon is skipped and selenocystein can be inserted during translation into the maturing protein. Sec-tRNA also needs to undergo isopentylation and the absence of isopentylated $t$ RNA could result in improper translation by inserting a stop codon instead of Sec. This may lead to premature termination of translation and production of truncated, nonfuctional proteins. A recent study investigated the isopentenylation of selenocysteine tRNA in selenoprotein synthesis after in vivo statin treatment. Most cellular selenoproteins investigated were reduced, some of them more than $90 \%$ [47]. Truncated proteins were found in large amounts, due to the premature abortion of translation, and were rapidly degraded.

\section{Mitochondria}

Ubiquinone (CoQ10) is an isoprenoid which plays an important role as electron transporter in the mitochondrial respiratory chain and supports ATP synthesis. CoQ10 is dissolved in the hydrophobic region of the inner membrane of mitochondria. It can move freely within the hydrophobic region of the membrane by passive diffusion, where it acts as a mobile electron carrier of the electron-transport chain. CoQ10 collects reducing equivalents from the less mobile NADH-Q reductase and passes them onto the cytochromes further downstream the respiratory chain. Reduction of CoQ10 is known to impair mitochondrial function and hence contributing to the development of myopathies. 
As statins block the intracellular CoQ10 synthesis, it is reasonable that statininduced CoQ10 reduction is hypothesized to participate in statin-associated myopathies [48]. Krähenbühl et al. showed that statins are mitochondrial toxins affecting the electron transport chain. The group used isolated rat skeletal muscle mitochondria and a rat skeletal cell line (L6) to show that lipophilic statins decrease the mitochondrial membrane potential, induce mitochondrial swelling, impair mitochondrial $\beta$-oxidation, uncouple oxidative phosphorylation, and finally induce apoptosis [37]. On the other hand statins did not reduce CoQ10 levels in skeletal muscle cells (except of high dose simvastatin treatment), although they are shown to reduce CoQ10 serum levels [48]. Still, the role of CoQ10 in statin associated myopathies is unclear and a direct association between reduced intramuscular CoQ10 levels and mitochondrial myopathy has not been conclusively shown [48]. It seems more likely that CoQ10 is a critical predisposing factor, especially for patients with other CoQ10 reducing conditions, and does not appear to be the main cause of statin-induced myopathy [48].

\subsubsection{Molecular targets of adverse statin effects}

Taken together, the discussed mechanisms of statin myotoxicity are highly complex because the list of potentially affected intermediates, particularly those of isoprenoid metabolism, is quite large. Furthermore, it is still unclear whether statins need to be taken up into muscle cells or whether they can act from the plasma membrane to unveil their toxic potential. Currently the following two hypotheses are under discussion how statins initiate myopathies. To induce myopathies from outer cell, statins need to bind or interact with components of the cell membrane to transmit the signal across the membrane into the cell. The second hypothesis claims that statins need to be transported across the cell membrane to become toxic from inside the cell. Evidence for this concept is given by the fact that not only lipophilic statins but also the hydrophilic pravastatin can induce myopathies [49]. It is hard to conceive that lipophilic statins can enter muscle cells without a transport mechanism. Indeed it is doubtful, whether passive diffusion of drugs across plasma membranes exists at all [50]. The group of Endou et al. was the first group to show the expression of a potential statin transporter in human skeletal muscle, namely OAT1 and OAT3 [51]. 
They further demonstrated the uptake of pravastatin via OAT3 in a heterologous expression system.

In 2008 Sakamoto et al. demonstrated the expression of the uptake transporters Oatp1a4 and Oatp2b1 in rat skeletal myofibers but not in satellite cells and fibroblasts. They found that pravastatin induces cell death only in myofibers and not in satellite cells and fibroblasts, supporting the importance of the statin transporters. They further demonstrated that concomitant treatment with the OATP substrate ES3 prevented cell death, which was not the case when cells were co-incubated with the OAT substrate PAH (p-aminohippuric acid) strengthening the evidence that Oatps are involved in pravastatin uptake into myofibers [52]. Recently Knauer et al. demonstrated the expression of OATP2B1 on the sarcolemmal membrane of human skeletal muscle fibers [53]. The same group also showed that transfection of OATP2B1 into human skeletal muscle myoblasts increases intracellular accumulation and toxicity of rosuvastatin and atorvastatin in these cells [53]. These recent studies increase the awareness that transport proteins might play a more important role in statin-induced myopathies than hitherto expected. Further in vivo and in vitro studies are still needed to better understand statin-induced pathophysiological mechanisms in muscle and the role of transport proteins.

\subsection{Transport proteins}

The target organ of statins is the liver. Therefore, it is essential that a high proportion of the oral administered drug enters the hepatocyte, which is facilitated by protein mediated transport. In the last years drug transporters have been recognized more and more to be important for drug discovery and development as they function as gatekeepers enabling the uptake and efflux of therapeutic substances and endogenous agents into and out of cells, and thereby play a major role for absorption, distribution, and excretion of endogenous compounds and drugs $[54,55]$. Based on their mechanism of function, transporters can be divided into active and passive transporters. Active transporters can establish a concentration gradient of solutes or ions across a membrane by using diverse energy-coupling mechanisms. They can be further divided into primary- or secondary-active transporters. Primary-active transporters utilize metabolic energy like ATP to transport molecules across a membrane. ABC 
(ATP-binding cassette) transporters and ATPases belong to the class of primaryactive transporters and translocate solutes or ions out of the cell or into cell organelles. Secondary-active transporters utilize the established and maintained electrochemical gradient of primary-active transporters as energy resource by ion-coupling to translocate nutrients against their concentration gradient across a membrane.

Facilitated transporters are passive transporters allowing the diffusion of solutes down their electrochemical gradient across a membrane with a fixed number of solutes per translocation cycle. Channels are similar to passive transporters. Here, the flow of solutes or ions is controlled by a gating mechanism and follows the electrochemical gradient. The rate of transport is much faster compared to passive transporters and is depending on the concentration of ions or solutes and the membrane potential. The conductance of a channel is depending on the surrounding milieu or on a directed signal which determines the open probability of the channel.

\subsection{OATPs}

\subsubsection{Nomenclature}

The organic anion transporting polypeptides (rodent: Oatps; human: OATPs) are a class of influx transport proteins within the SLC superfamily. Based on phylogenetic features, the nomenclature of its members was standardized and updated in 2004, and the originally named SLC21A superfamily was renamed to SLCO (Solute carrier family of the OATPs) [56]. So far more than 300 members of the OATP/SLCO superfamily have been identified, thereof 11 expressed in humans, which are classified into six families based on their similarity of the amino acid sequence [57].

The first member of OATP superfamily was isolated and cloned by Jaquemin et. al in 1993 from rat liver by using expression cloning in Xenopus laevis oocytes [58] and was shown to have properties of a sodium independent organic anion transporter. The first human OATP (now called OATP1A2) was isolated by Kullak-Ublick et. al [59] from human liver but shows highest expression in cerebral capillary endothelial cells of the blood-brain barrier [60]. While most 
OATPs/Oatps are expressed in multiple tissues, including the liver, kidney, intestine, blood-brain barrier, choroid plexus, placenta, lung, testes and heart, some are selectively expressed in certain tissue like OATP1B1 and -1B3 (both in the liver).

\subsubsection{Substrate specificity}

OATPs/Oatps mediate transport of numerous endogenous and exogenous substances across the cell membrane in a ATP- and sodium-independent manner [57]. In general, substrates are amphipathic molecules with molecular weights greater than 350 Daltons [56]. OATPs facilitate the uptake of a broad range of substrates including steroid conjugates, bile acids, thyroid hormones, linear and cyclic peptides as well as numerous xenobiotics including mushroom toxins, antibiotics, sartans, statins and anticancer drugs. Numerous substances are transported by several OATPs, like estrone-3-sulfate (E3S), estradiol-17 $\beta$ glucuronide $(\mathrm{E} 17 \beta \mathrm{G})$ or bromosulphophthalein (BSP), which makes them useful model substrates. Recent investigations indicate that OATPs have multiple substrate binding sites. For OATP1B1 it has been shown to have a biphasic saturation kinetic for E3S, suggesting the presence of both a low-affinity, highcapacity binding site and a high-affinity, low-capacity binding site. Depending on the substrate used, inhibition studies have shown that compounds can have inhibitory, stimulatory or no effect on OATP-mediated transport [61, 62].

Recent studies show that OATPs can perform transport in both directions and that they work as electroneutral exchangers. Leuthold et al. showed that OATP/Oatp substrate transport generally leads to stimulation of bicarbonate efflux, which supports the concept that OATPs/Oatps act as anion exchangers [63]. Furthermore, $\mathrm{pH}$ can affect the efficacy of substrates transported via OATPs. Acidic extracellular environment in general stimulates transport activity of OATPs /Oatps [25]. The authors further suggest that the $\mathrm{pH}$ dependent transport is linked to a highly conserved histidine in the third transmembrane domain. This area is also involved in altered transport properties of polymorphic OATPs [25]. OATP2B1 has been shown to increase transport activities under acidic conditions caused by higher substrate affinity [64]. The reason for this phenomenon can be explained by the protonation of a conserved histidine residue at the extracellular end of transmembrane domain three. Being also expressed in the 
small intestine, OAPT2B1 can thus facilitate the absorption of clinically relevant drugs due to increased transport and wider range of substrates [65].

\subsubsection{Structure}

All OATP/Oatp family members share a very similar topology. Based on computational analyses they consist of 12 transmembrane domains with a large extracellular loop five, harboring the $\mathrm{C}$ - and N-treminal end inside the hepatocyte (Fig. 2). Meier-Abt et al. presented for the first time a three dimensional struc-

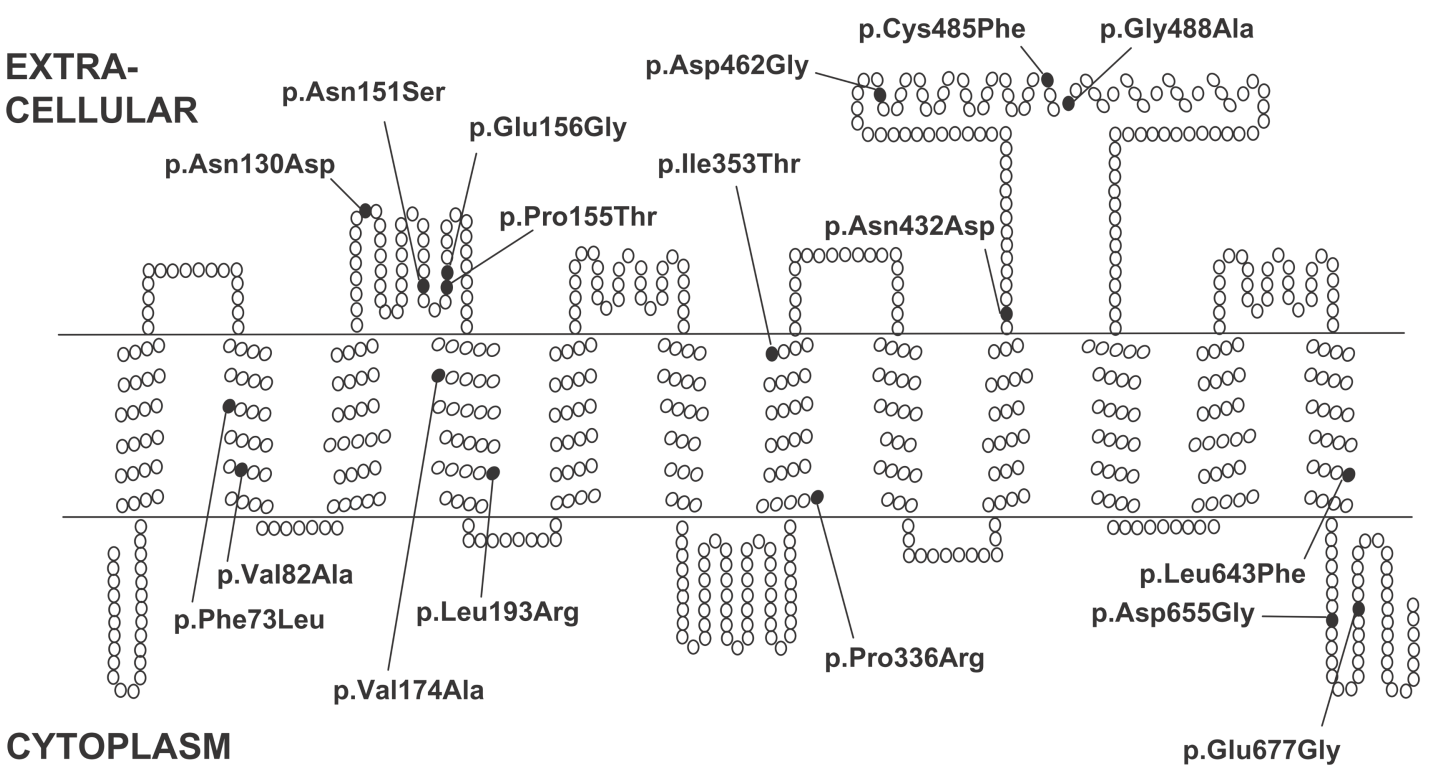

Fig. 2: Structure of OATP1B1

Topological scheme of the secondary structure of OATP1B1, showing the 12 transmembrane domains and known single nucleotide polymorphisms (SNPs). Adapted from [28].

tural model for all OATPs/Oatps where they propose that OATPs/Oatps function in a rocker-switch type of transport mechanism [56] . In this mechanism, the transport protein is believed to have two major alternating conformations: inward-facing and outward-facing. Here, the substrate is translocated through a central, positively charged pore, which is a common and likely to be a conserved feature of all OATPs/Oatps and functionally significant. However, the exact identification of a substrate binding site and other sites critically involved in substrate translocation requires further studies to reveal the exact mechanism of substrate transport. 


\subsubsection{The hepatocellular OATPs 1B1 and 1B3}

The hepatocyte-specific OATP1B1 (SLCO1B1) and OATP1B3 (SLCO1B3) are multispecific organic anion transporting proteins exhibiting an amino acid sequence identity of $80 \%$. They are localized at the sinusoidal membranes and mediate the influx of their substrates from sinusoidal blood plasma into hepatocytes. Thus, they represent an important step in clearance of clinically relevant drugs by metabolism or biliary excretion. Both proteins mediate transmembrane transport of endogenously synthesized substances including bile salts like cholate, glycocholate and taurocholate [66], conjugated steroids like E17ßG, E3S, dehydroepiandrosterone sulfate (DHEAS) [67] and other organic ions like BSP and bilirubin [68, 69]. Besides endogenously synthesized substances OATP1B1 and -1B3 mediate hepatocellular uptake of a variety of different drug substrates like methotrexate, rifampicin and several statins [66, 67]. Both OATPs have been identified to be the major player in hepatocellular uptake of statins, besides OATP2B1, as they mediate the hepatocellular-uptake of almost all statins $[67,68]$. For OATP1B1 several polymorphisms have been described [70] and a genome-wide association study linked SLCO1B1 polymorphisms to an increased risk of statin-induced myopathy [71], thereby supporting the important role of OATP1B1 in the hepatic uptake and elimination of statins and possibly of other drugs.

\subsection{Cell systems to study statin toxicity}

Skeletal muscle consists of multi-nucleated muscle cells called myofibers, which have a long cylindric shape. Myofibers arise during myogenesis from several undifferentiated myoblasts by cell to cell membrane fusion. During development, embryonic progenitor cells enter differentiation phase and initiate withdrawal from the cell cycle. These cells are called myoblasts and start to express various genes encoding structural proteins soon after initiation of differentiation. Myoblasts can then fuse with one another to form a nascent multinucleated myofiber [72]. Myoblast fusion is a fundamental step in the differentiation of muscle and is initiated by muscle specific gene expression and facilitated by glycoproteins called cell-cell fusogens $[73,74]$. The nascent myofiber undergoes further maturation by increasing size, which requires further 
cell fusion with myoblasts or other myofibers and the expression of contractile proteins [74]. In vitro, myofibers are called myotubes, due to their tubular shape. The possibilities of investigating statin-induced myotoxicity encompasses a wide range of in vitro tools. The fundament of these tools is always built by tissue explants, primary cells, or immortalized cell lines obtained from various sources like human donors or rodents. Bischoff et al. successfully isolated single live muscle fibers from the flexor digitorum brevis (FDB) of adult rats and thereby created an in vitro system where the physical association between the myofiber and its stem cells is preserved [75]. Skeletal muscles are composed of multinucleated myofibers with a length of several centimeters which makes it difficult to culture them ex vivo. Myoblasts acquired primarily from skeletal muscles permit a reasonable alternative. Already in 1968, Yafee described a method how to extract myogenic cells from thigh muscle of newborn rats, nowadays known as L6 myoblasts [76]. A few years later the same group isolated myoblasts from thigh muscles of newborn mice, today known as C2C12 myoblasts [77]. Cells of both myogenic cell lines are able to fuse and form long and multinucleated myotubes under appropriate culture conditions, representing an in vitro model of myofibers. Thus, L6 as well as $\mathrm{C} 2 \mathrm{C} 12$ provide an excellent model to study muscle related questions. It is also possible to isolate muscle cells from humans. Primary human skeletal muscle cells (SkMC) are isolated from different skeletal muscles from adult donors. New skeletal muscle cells originate from quiescent satellite cells, which are located in the muscle fibers between the basal lamina and the sarcolemma. Quiescent satellite cells are activated by stimuli such as muscle damage. After activation, the cells, now called myoblasts, start to proliferate and fuse with damaged muscle fibers or with one another forming new myotubes.

Yet another possibility to investigate muscle related issues is given by tumor cell lines derived from human rhabdomyosarcoma (RMS). RMS is a neoplasm arising from skeletal muscle precursor cells (myoblasts) and is the most common soft tissue sarcoma in children. Of the two major subtypes of RMS, embryonal and alveolar, currently 30 cell lines are described in the literature (18 embryonal, 12 alveolar) [78]. One of the most commonly used cell line is RD and is derived from a 7-year-old girl with a pelvic RMS [79]. 


\subsection{Aims of the presented work}

The overall aim of the thesis was to investigate the mechanism how statins induce toxicity in muscle cells. More precisely, the aim was to distinguish between statin-induced myotoxicity originating at the plasma membrane of muscle cells from events occurring intracellular after uptake of statins.

As a first step we aimed to study the role of OATPs in statin-induced cellular damage in non-muscle cells. The already established fibroblast cell line $\mathrm{CHO}$, expressing the human transporters OATP1B1, -1B3, or -2B1 was used to elucidate the toxic potential of different statins and to investigate whether the susceptibility against statins varies between the $\mathrm{CHO}$ cell lines expressing different OATPs and the wild type.

Second, we aimed to establish a cell line stably expressing a membrane transporter of the OATP family, responsible for statin uptake in human hepatocytes. Therefore, a rat (L6) and a mouse (C2C12) skeletal muscle cell line was transfected with OTAP1B1 or OATP1B3 cDNA. These new cell lines were used to discriminate between extracellular and intracellular toxicity of statins.

The third aim was to investigate the capability of statins to induce apoptosis by measuring caspase- 3 activity after statin treatment. The new established cell lines were compared to the non-transfected cells to elucidate the role of a statin carrier in statin-induced apoptosis. 


\section{Materials And Methods}

\subsection{Materials}

All chemicals were of the highest degree of purity available from commercial sources. Caspase-3 substrate Ac-DEVD-AMC was obtained from Bachem (Bubendorf, Switzerland). Fetal calf serum (FCS) was US-origin und purchased from Life Technologies ${ }^{\mathrm{TM}}$ (Carlsbad, CA, USA). Atorvastatin calcium trihydrate, cerivastatin sodium, pravastatin sodium, rosuvastatin calcium and simvastatin were obtained from LKT Laboratories, Inc. (St. Paul, MN, USA). [ $\left.{ }^{3} \mathrm{H}\right]$-Estrone3-sulfate (45.0 Ci / mmol) was obtained from PerkinElmer (Waltham, Massachusetts, USA). Cerivastatin $\left[{ }^{3} \mathrm{H}(\mathrm{G})\right]$ sodium salt $(5.0 \mathrm{Ci} / \mathrm{mmol})$, pravastatin $\left[{ }^{3} \mathrm{H}(\mathrm{G})\right]$ sodium salt $(5.0 \mathrm{Ci} / \mathrm{mmol})$, simvastatin lactone $\left[{ }^{3} \mathrm{H}(\mathrm{G})\right](5.0 \mathrm{Ci} / \mathrm{mmol})$ were obtained from American Radiolabeled Chemicals, Inc. (St. Louis, MO, USA). Chinese hamster ovary $(\mathrm{CHO})$ cells expressing OATP1B1, OATP1B3 or OATP2B1 and control cells were available in the lab and have been previously described [61, 80]. L6 and C2C12 cells were a kind gift from Prof. Stephan Krähenbühl, Clinical Pharmacology \& Toxicology, University Hospital Basel. Primary antibodies recognizing OATP1B1 or OATP1B3 were available in the lab and have been described earlier [81]. Primary antibody recognizing the middle region of OATP1B1 was obtained from Aviva Systems Biology (San Diego, CA, USA). Primary mouse monoclonal antibody recognizing the N-terminus of OATP1B1 was obtained from Creative Diagnostics (Shirley, NY, USA). Secondary antibody Alexa Fluor ${ }^{\circledR} 488$ goat anti-rabbit IgG $(\mathrm{H}+\mathrm{L})$ was obtained from Molecular Probes (Eugene, OR, USA). Secondary antibody goat anti-rabbit IgG horseradish peroxidase was obtained from GE healthcare (Buckinghamshire, UK). 


\subsection{Methods}

\subsubsection{Cell culture}

CHO wild type cells were grown in Dulbecco's modified Eagle's medium (DMEM) at low glucose levels $(1 \mathrm{~g} / \mathrm{L})$ supplemented with 10\% FCS, 2 mM L-Glutamine, $100 \mathrm{U} / \mathrm{ml}$ penicillin and $100 \mu \mathrm{g} / \mathrm{ml}$ streptomycin and $50 \mu \mathrm{g} / \mathrm{ml} \mathrm{L}$-proline at $37^{\circ} \mathrm{C}$ with $5 \% \mathrm{CO}_{2}$ and 95\% humidity. CHO cells expressing OATP1B1, OATP1B3 or OATP2B1 [61,80] contained additionally $500 \mu \mathrm{g} / \mathrm{ml} \mathrm{G}-418$ sulfate. L6 and C2C12 cells were grown in DMEM at high glucose level $(4.5 \mathrm{~g} / \mathrm{L})$ supplemented with 10\% FCS, 4 mM L-Glutamine, 12.5 mM HEPES (4-(2-hydroxyethyl)-1-piperazineethanesulfonic acid). Medium to culture L6 and C2C12 cells expressing OATP1B1 or OATP1B3 contained additionally $500 \mu \mathrm{g} / \mathrm{ml}$ G-418 sulfate and will be termed as selection medium in the text later on.

\subsubsection{Differentiation of myoblast into myotubes}

To differentiate L6 and C2C12 cells from myoblasts into myotubes, cells were treated for at least five days but no longer than 20 days with differentiation medium with or without Insulin $(9.5-10.5 \mathrm{mg} / \mathrm{mL})$. For differentiation DMEM medium at high glucose level was used $(4.5 \mathrm{~g} / \mathrm{L})$ supplemented with $2 \%$ Horse serum, 4 mM L-Glutamine, 12.5 mM HEPES. Medium was exchanged every 2-3 days.

\subsubsection{Transfection}

\subsubsection{Killing curve}

A cell survival assay using alamarBlue ${ }^{\circledR}$ with L6 and C2C12 wild type cells was performed to obtain a killing curve. Cells were seeded in 48-well plates with 2000 cells per well and incubated at $37^{\circ} \mathrm{C}$ and $5 \% \mathrm{CO}_{2}$. After $24 \mathrm{~h}$ the medium was exchanged by medium containing the proper G418 concentration (Tab. 2). Medium was exchanged periodically on the $3^{\text {rd }}, 5^{\text {th }}, 7^{\text {th }}$ and $11^{\text {th }}$ day. Cell viability was measured at day 11 by adding $30 \mu \mathrm{l}$ (10\% of total volume) of 
alamarBlue ${ }^{\circledR}$ to every well and cells were incubated at $37^{\circ} \mathrm{C}$ for $4 \mathrm{~h}$. Fluorescence was measured using the plate reader "Twinkle LB970" (Berthold Technologies, Bad Wildbad, Germany) with excitation wavelength of $560 \mathrm{~nm}$ and emission wavelength of $590 \mathrm{~nm}$. The lowest concentration that kills $100 \%$ of the wild type cells was chosen to treat cells after transfection. Data were analyzed using a four parameter logistic nonlinear regression model.

\begin{tabular}{|r|r|r|}
\hline Condition & total volume $[\boldsymbol{\mu} \mathbf{]}]$ & final conc. [ $\mathbf{\mu g} / \mathbf{m l ]}$ \\
\hline $\mathbf{1}$ & $12^{\prime} 000$ & 0.0 \\
\hline $\mathbf{2}$ & $12^{\prime} 000$ & 62.5 \\
\hline $\mathbf{3}$ & $12^{\prime} 000$ & 125.0 \\
\hline $\mathbf{4}$ & $12^{\prime} 000$ & 250.0 \\
\hline $\mathbf{5}$ & $12^{\prime} 000$ & 500.0 \\
\hline $\mathbf{6}$ & $12^{\prime} 000$ & 750.0 \\
\hline $\mathbf{7}$ & $12^{\prime} 000$ & 875.0 \\
\hline $\mathbf{8}$ & $12^{\prime} 000$ & 1000.0 \\
\hline $\mathbf{9}$ & $12^{\prime} 000$ & 1125.0 \\
\hline $\mathbf{1 0}$ & $12^{\prime} 000$ & 1250.0 \\
\hline $\mathbf{1 1}$ & $12^{\prime} 000$ & 1375.0 \\
\hline $\mathbf{1 2}$ & $12^{\prime} 000$ & 1500.0 \\
\hline $\mathbf{1 3}$ & $12^{\prime} 000$ & 1625.0 \\
\hline $\mathbf{1 4}$ & $12^{\prime} 000$ & 1750.0 \\
\hline $\mathbf{1 5}$ & $12^{\prime} 000$ & 2000.0 \\
\hline
\end{tabular}

Tab. 2: Concentrations of G-418 used to obtain a killing curve for L6 and C2C12 cells.

\subsubsection{Preparation of the expression vector}

The expression plasmids pIRESneo 2 (Clontech ${ }^{\circledR}$, Paris, France) containing OATP1B1 or OATP1B3 were available in the lab and were prepared by the group of Prof. Hagenbuch [61]. The cDNA of OATP1B1 or OATP1B3 was cloned from pIRESneo2 into the pcDNA3.1+ by sequential digestion using NotI first and subsequent NheI. The schematic of both vectors is shown in Fig. 3. Restricted DNA was separated by gel electrophoresis and subsequently gel purified using the QIAquick Gel Extraction Kit (Qiagen ${ }^{\circledR}$, Limburg, Netherlands). Afterwards DNA was ligated and transformed into E.coli TOP10. Transformed E.coli were plated on LB agar plates (35.6 g/L LB Agar EZMix ${ }^{\mathrm{TM}}$ in $\mathrm{ddH}_{2} \mathrm{O}, 50 \mu \mathrm{g} / \mathrm{ml}$ carbenicillin) and grown overnight at $37^{\circ} \mathrm{C}$. Several clones were picked and grown overnight in LB medium (20.6 g/ L LB Broth EZMix ${ }^{\mathrm{TM}}$ Powder in $\mathrm{ddH}_{2} \mathrm{O}, 50 \mu \mathrm{g} / \mathrm{ml}$ 
carbenicillin) shaking at $37^{\circ} \mathrm{C}$. DNA was then isolated with the GeneJET Plasmid Miniprep Kit (Thermo Fisher Scientific, Zurich, $\mathrm{CH}$ ) and sent for sequencing to Microsynth ${ }^{\circledR}($ Zurich, $\mathrm{CH})$ using their in-house standard primers (T7: TAATACGACTCACTATAGG, BGH-rev: TAGAAGGCACAGTCGAGG).

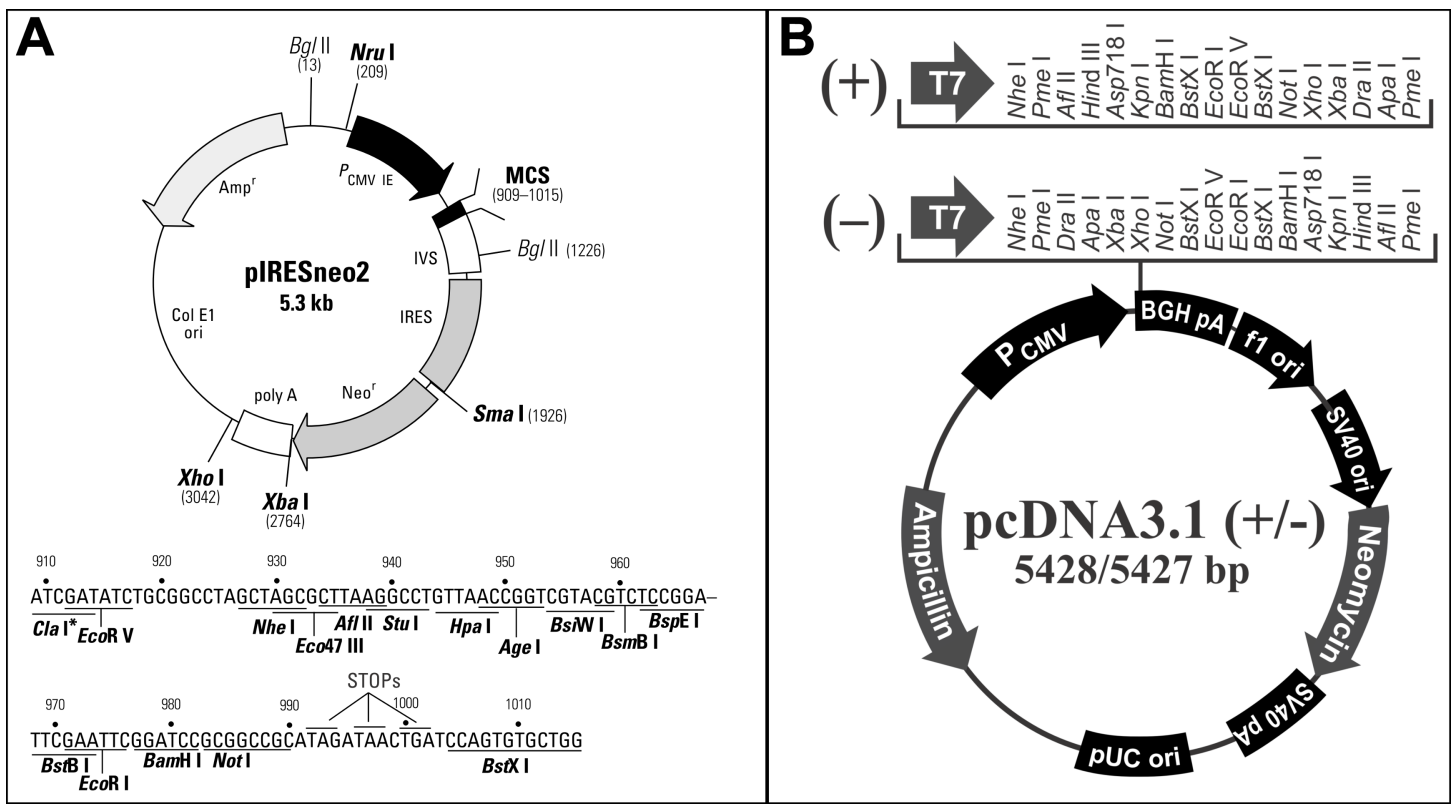

Fig. 3: Vectors used for transfection.

Schematic of the vector pIRESneo2 (A) and pcDNA3.1+ (B)

To check for mutations the sequence of the inserted cDNA was sequenced using the primers given in Tab.3. Primers were chosen to bind after every 600 bp's. The selected plasmids were linearized at the XhoI restriction site for one hour at $37^{\circ} \mathrm{C}$ using the FastDigest ${ }^{\circledR}$-system (Thermo Fisher Scientific, Zurich, $\mathrm{CH}$ ). Linearized DNA was purified using the GeneJET PCR Purification Kit (Thermo Fisher Scientific, Zurich, $\mathrm{CH}$ ) and checked for proper linearization using agarose gel electrophoresis.

\subsubsection{Chemical transfection}

FuGENE HD transfection agent (FuGENE) was used to transfect cells chemically. In detail, L6 $\left(2 \cdot 10^{5}\right.$ cells/well) and C2C12 (4.10 5 cells/well) cells were seeded in 6 well plates and incubated at $37^{\circ} \mathrm{C}$ and $5 \% \mathrm{CO}_{2}$ for $24 \mathrm{~h}$. As recommended by the supplier different ratios of FuGENE and DNA were applied. The different ratios as well as the respective cell lines and plasmids (DNA) used are listed in Tab. 4. 


\begin{tabular}{|l|l|}
\hline \multicolumn{2}{|c|}{ OATP1B3 (2710bp's ) } \\
\hline Primer (Primer position) & Sequence of primer \\
\hline T7 (Start) & TAATACGACTCACTATAGG \\
\hline Primer 1 (580- 601) & GGAACATCACCTGAGATAGTAG \\
\hline Primer 2 (1215-1235) & GGAGCAACAGTACGGTCAGTC \\
\hline Primer 3 (1800-1820) & GACTGTGAAGATTGTTCAACC \\
\hline Primer 4 (2399-2422) & GGTTAAGATTAGAATATATGATCC \\
\hline BGH-rev (End) & TAGAAGGCACAGTCGAGG \\
\hline \multicolumn{2}{|c|}{ OATP1B1 (2800bp's) } \\
\hline Primer (Primer position) & Sequence of primer \\
\hline T7 (Start) & TAATACGACTCACTATAGG \\
\hline Primer 1 (596- 618) & GGATCTGGGTCATACATGTGG \\
\hline Primer 2 (1206-1225) & GGTCAGCCTTCATCTAAGGC \\
\hline Primer 3 (1820-1839) & GGGTTTCCACTCAATGGTTA \\
\hline Primer 4 (2394-2418) & GGTTAAGGTTAGACTATATGATCC \\
\hline BGH-rev (End) & TAGAAGGCACAGTCGAGG \\
\hline
\end{tabular}

Tab. 3: Primers used for complete insert sequencing after OATP1B3 or OATP1B1 was cloned into the plasmid vector pcDNA3.1+, respectively.

\begin{tabular}{|c|c|c|c|c|}
\hline Cell line & Transporter & \multicolumn{3}{|c|}{ FuGENE:DNA ratio } \\
\hline \multirow{2}{*}{ L6 } & OATP1B1 & $5: 2$ & $7: 2$ & $9: 2$ \\
\cline { 2 - 5 } & OATP1B3 & $5: 2$ & $7: 2$ & $9: 2$ \\
\hline \multirow{2}{*}{ C2C12 } & OATP1B1 & $5: 2$ & $7: 2$ & $9: 2$ \\
\cline { 2 - 5 } & OATP1B3 & $5: 2$ & $7: 2$ & $9: 2$ \\
\hline
\end{tabular}

Tab. 4: Scheme of all transfection conditions used for chemical transfection.

The complexing process of DNA and FuGENE was performed in FCS free medium Opti-Mem ${ }^{\circledR}$. For transfection, $150 \mu \mathrm{l}$ of complexing solution containing $3 \mu \mathrm{g}$ DNA were added directly to every well without removing medium. Medium was replaced by selection medium containing $1 \mathrm{mg} / \mathrm{ml} \mathrm{G} 418$ after $24 \mathrm{~h}$ and changed every $3^{\text {rd }}$ day for 8-10 days. When 6-well plates where confluent again, cells were harvested by trypsinization and resuspended in selection medium

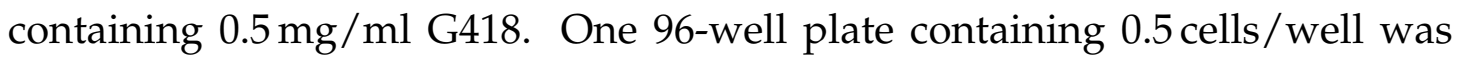
prepared from every transfection condition for limiting dilution cloning. The residual cell suspension was transferred to two $35 \mathrm{~mm}$ dish for RNA extraction and to one $10 \mathrm{~cm}$ dish for freezing the cells.

\subsubsection{Physical transfection}

Electroporation was used to physically transfect L6 and C2C12 cells, based on the protocol of Noya et al. [82]. In detail, cells were harvested from a confluent $10 \mathrm{~cm}$ dish, washed twice in PBS (phosphate buffered saline) and resuspended in $3.5 \mathrm{ml}$ PBS. $0.8 \mathrm{ml}$ of the cell suspension was transferred to a $0.4 \mathrm{~cm}$ electroporation cuvette. After adding $50 \mu \mathrm{l}$ of DNA (OATP1B1 linearized plasmid: $232.86 \mathrm{ng} / \mu \mathrm{l}$, OATP1B3 linearized plasmid: $588.80 \mathrm{ng} / \mu \mathrm{l})$ cells were incubated 
for $10 \mathrm{~min}$ on ice. Electroporation was conducted using the GenePulser ${ }^{\circledR}$ (BioRad) instrument with the following settings:

- Capacitor: $960 \mu \mathrm{F}$,

- Voltage: $0.22 \mathrm{KV}$,

- Resistor: 100 Ohms.

After electroporation cells were transferred back to a $10 \mathrm{~cm}$ dish containing fresh L6/C2C12 culture medium without Pen/Strep. Medium was replaced by selection medium containing $1 \mathrm{mg} / \mathrm{ml} \mathrm{G} 418$ after $24 \mathrm{~h}$ and changed every $3^{\text {rd }}$ day for 12 days.

\subsubsection{Limiting dilution cloning}

To obtain a monoclonal cell population from a polyclonal mass of cells after transfection a limiting dilution assay was performed. In detail, cells were harvested after they recovered from transfection by trypsinization and subsequently

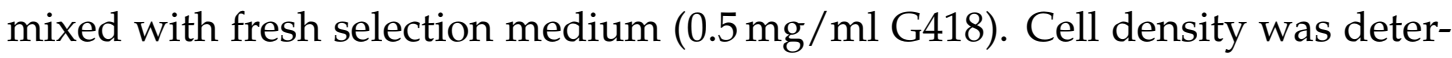
mined using the automated cell counter Countess ${ }^{\circledR}$ (Life Technologies, Carlsbad, CA, USA) and thereafter diluted to a density of 5 cells $/ \mathrm{ml}$ with selection medium. $100 \mu \mathrm{l}$ of this solution was pipetted into every well of a 96-well plate to reach a concentration of 0.5 cells/well. The plates were incubated at $37^{\circ} \mathrm{C}$ and $5 \% \mathrm{CO}_{2}$. All 96-well plates were observed on a daily basis and medium was exchanged every 3-4 days upon colony formation. Cells of confluent wells were transferred to 6-well plates and later to $10 \mathrm{~cm}$-dishes to increase the cell population. Wells containing more than one colony were dropped out.

\subsection{4 qRT-PCR using TaqMan ${ }^{\circledR}$-based gene expression analy- sis}

Cells to be analyzed were seeded on $35 \mathrm{~mm}$ dishes and incubated at $37^{\circ} \mathrm{C}$ and $5 \% \mathrm{CO}_{2}$ until confluency. After aspiration of medium, $500 \mu \mathrm{l}$ of Trizol ${ }^{\circledR}$ were added to every dish and cells were homogenized by pipetting up and down ten times and flushing the surface of the culture dish. Cell homogenate was transferred to an Eppendorf ${ }^{\circledR}$-Tube and stored at $-20^{\circ} \mathrm{C}$ until further processing. After thawing, RNA was isolated following the "RNA Isolation Procedure" given in 
the Trizol ${ }^{\circledR}$ reagent manual without adding glycogen [83]. RNA was eluted in 30-50 $\mu \mathrm{l}$ RNase free water and concentration was measured using spectrophotometer NanoDrop ND-1000 (Thermo Fischer Scientific, Zurich, CH). For reverse transcription the High Capacity cDNA Reverse Transcription Kit (Life Technologies $^{\mathrm{TM}}$, Carlsbad, CA, USA) was used. $10 \mu \mathrm{l}$ of sample containing $1 \mu \mathrm{g}$ of RNA were mixed with $10 \mu$ l of RT-Master mix (2.0 $\mu$ l, 10x RT Buffer, $0.8 \mu 125 x$ dNTP, $2.0 \mu \mathrm{l}$ Random Primers, $1.0 \mu \mathrm{l}$ RT Multiscribe ${ }^{\circledR}$ Reverse Transcriptase, $1.0 \mu \mathrm{l}$ RNases inhibitor, $3.2 \mu \mathrm{l}$ RNase free water) and incubated for $60-90 \mathrm{~min}$ at $37^{\circ} \mathrm{C}$. To stop the reverse transcription samples were heated up to $85^{\circ} \mathrm{C}$ for $5 \mathrm{~min}$ and afterwards cooled on ice. The obtained cDNA was diluted with $40 \mu \mathrm{l}$ RNase free water. To perform qRT-PCR, $2 \mu$ l of the diluted cDNA was mixed with $8 \mu \mathrm{l}$ TaqMan-Master mix (5.0 $\mu \mathrm{l}$ 2x TaqMan ${ }^{\circledR}$ Fast Universal PCR Master Mix, $0.5 \mu \mathrm{l}$ 20x Primer, $2.5 \mu \mathrm{l}$ RNase free $\mathrm{H}_{2} \mathrm{O}$ ) in a 348-well plate in triplicates.

\subsubsection{Preparation of total membrane fraction}

Cells were grown in $10 \mathrm{~cm}$ dishes till confluency at the day of the preparation and treated with or without $5 \mathrm{mM}$ sodium butyrate $(\mathrm{NaB}) 24 \mathrm{~h}$ prior the preparation [84]. Dishes were rinsed three times with PBS and once with $0.25 \mathrm{mM}$ sucrose. After adding $1 \mathrm{ml}$ of harvest solution ( $5 \mathrm{mM}$ sucrose, $2 \mathrm{mM}$ PMSF, $1 \mathrm{mg} / \mathrm{ml}$ antipain-leupeptin) cells were scraped off using a cell scraper. To prevent protein degradation all subsequent steps were performed on ice. Scraped cells were frozen at $-80^{\circ} \mathrm{C}$ overnight and thawed in an ultrasonic bath for $2 \mathrm{~min}$. The cell suspension was homogenized using a $1 \mathrm{ml}$ syringe and $30 \mathrm{G}$ needle. The homogenate was centrifuged for $10 \mathrm{~min}$ at $4^{\circ} \mathrm{C}$ and $800 \mathrm{~g}$. To pellet the membrane fraction, the supernatant was centrifuged for $1 \mathrm{~h}$ at $100,000 \mathrm{~g}$. After decanting the supernatant the pellet was resuspended in $150 \mu \mathrm{l}$ resuspension buffer (250 mM sucrose, $2 \mathrm{mM}$ PMSF, $1 \mathrm{mg} / \mathrm{ml}$ Antipain-Leupeptin). Protein concentration was determined using the BCA assay.

\subsubsection{Western blotting}

Western blotting was used to test the expression of OATP1B1- or OAPT1B3protein in transfected L6 and C2C12. Membrane fractions or whole cell lysates were used as starting material. Whole cell lysate was prepared from a confluent 
$10 \mathrm{~cm}$ dish, which was treated in the presence or absence of $(\mathrm{NaB}) 24 \mathrm{~h}$ before lysing the cells. After aspirating the medium and washing with PBS twice, $1 \mathrm{ml}$ of RIPA-Buffer (150 mM NaCl, 1\% NP40, 0.5\% w/v Sodium deoxycholate, $1 \mathrm{mM}$ EDTA, $0.1 \%$ SDS, $10 \%$ Glycerol, $50 \mathrm{mM}$ Tris- $\mathrm{HCl} \mathrm{pH} 8.0$ ) was added to dissolve the cells. Cell suspension was homogenized using a 26G-needle and a 30G-needle consecutively. Protein concentration was determined using the BCA assay. Proteins of whole cell homogenates or membrane fractions where separated by SDS-PAGE on a $7.5 \%$ bis-acrylamide gel over night at $6 \mathrm{~mA}$ per gel using the "PROTEAN II xiCell" (BioRad). Separated proteins were transferred to a nitrocellulose membrane for $4 \mathrm{~h}$ in transfer buffer (192 mM Glycine, $25 \mathrm{mM}$ TRIS, $0.1 \% \mathrm{w} / \mathrm{v}$ SDS, 20\% v/v Methanol) using a voltage of $500 \mathrm{~V}$. After the transfer, membranes were blocked for $30 \mathrm{~min}$ in blocking solution ( $5 \%$ milk powder in TBS-T). TBS-T consists of $150 \mathrm{mM} \mathrm{NaCl}, 10 \mathrm{mM}$ Tris base, $0.1 \%$ w/v Tween-20, pH7.6 with HCL. Primary antibody was added directly to the blocking solution and thereby diluted depending on the antibody used. The incubation lasts for $2-4 \mathrm{~h}$ at room temperature (RT) or overnight at $4^{\circ} \mathrm{C}$. After washing three times with TBS-T the secondary antibody (goat anti-rabbit IgG HRP-conjugate diluted 1:30,000 or a goat anti-mouse IgG HRP-conjugate diluted 1:3,000) were applied in blocking solution for 1h at RT. Blots were washed three times with TBS-T and subsequently incubated with UptiLight ${ }^{\mathrm{TM}} \mathrm{HRP}$ blot substrate (Interchim, Montluçon, FRANCE) for 1 min at RT. Membranes were exposed to light sensitive films (Fuji Medical X-Ray Film) for $30 \mathrm{sec}, 1 \mathrm{~min}$ or $10 \mathrm{~min}$ in a light-tight cassette. Exposed films were developed using a medical film processor (Fujifilm, FPM 800a).

\subsubsection{Transport assay using radiolabeled or fluorescent substrates}

The transport assay with radio-labeled substrates in CHO, L6 and C2C12 cells was typically performed in $35 \mathrm{~mm}$ dishes in triplicates or quadruplicates [80]. Cells were grown to confluency at the day of the assay and treated with or without $\mathrm{NaB}(5 \mathrm{mM}) 24 \mathrm{~h}$ prior to the assay [84]. Individual dishes were rinsed three times with $2 \mathrm{ml}$ prewarmed sodium buffer and the uptake was started by adding $1 \mathrm{ml}$ of uptake solution which was composed of prewarmed sodium buffer and $0.3 \mu \mathrm{Ci} / \mathrm{ml}$ radiolabeled substrate supplemented with unlabeled substrate to adjust the required concentration. The sodium buffer (Earle's balanced salt solution) [85] consists of $5.3 \mathrm{mM} \mathrm{KCl}, 1 \mathrm{mM} \mathrm{NaH}_{2} \mathrm{PO}_{4} \cdot \mathrm{H}_{2} \mathrm{O}, 0.8 \mathrm{mM}$ 
$\mathrm{MgSO}_{4} \cdot 7 \mathrm{H}_{2} \mathrm{O}, 5.5 \mathrm{mM}$ D-Glucose, $20 \mathrm{mM}$ HEPES, $116.4 \mathrm{mM} \mathrm{NaCl}$, pH 7.4 with Tris base. For the fluorescence uptake assay, uptake solution was composed of prewarmed sodium buffer and 5-20 $\mathrm{mM}$ fluorescein. Dishes were incubated at $37^{\circ} \mathrm{C}$ for the given time on a heating plate or were kept in the cell incubator if the incubation time was longer than $5 \mathrm{~min}$. The uptake was stopped by aspiration of uptake solution and rinsing the cells four times with $2 \mathrm{ml}$ of ice cold sodium buffer $\left(4^{\circ} \mathrm{C}\right)$. To determine unspecific binding of the substrate to the cells the zero time point was determined by adding $1 \mathrm{ml}$ ice cold uptake solution after washing, followed by immediate aspiration and washing four times with $2 \mathrm{ml}$ ice cold sodium buffer. The cells were then solubilized with $1 \mathrm{ml} \mathrm{1 \%} \mathrm{Triton} \mathrm{X-100} \mathrm{(w/v)} \mathrm{for} \mathrm{at} \mathrm{least} 1 \mathrm{~h}$ at RT and gently shaking. For liquid scintillation counting $500 \mu$ l of the lysate were used, while the rest was saved for determining the protein concentration using the BCA assay. Net uptake values were obtained by subtracting uptake at $4^{\circ} \mathrm{C}$ from total uptake at $37^{\circ} \mathrm{C}$. The transport specific uptake was calculated as the difference in the uptake rate of the transfected and wild-type cells.

\subsubsection{BCA assay}

To determine the protein concentration, $25 \mu$ l of cell lysate were transferred into a well of a 96-well plate and diluted with $25 \mu$ l of distilled water. $25 \mu$ l of bovine serum albumin standard at different concentrations was diluted with $25 \mu \mathrm{l}$ of sample solvent. After adding BCA-solution, the plate was incubated at $37^{\circ} \mathrm{C}$ for $30 \mathrm{~min}$. Subsequently light absorption was measured at 550nm using the microplate reader "Ultramark (Bio-Rad, Hercules, CA, USA). The assay was performed in duplicates.

\subsubsection{Cell viability assay}

To assess the toxic potential of different statins on muscle and non-muscle cells, a cell viability assay using alamarBlue ${ }^{\circledR}$ was conducted. In this assay active metabolizing cells are converting resazurin, a non-fluorescent indicator dye, into highly red fluorescent resorufin via reduction reactions. Five different statins, atorvastatin, cerivastatin, pravastatin, rosuvastatin and simvastatin were tested at different concentrations. Therefore, cells were seeded in 48-well plates and 
incubated for $24 \mathrm{~h}$ at $37^{\circ} \mathrm{C}$ and $5 \% \mathrm{CO}_{2}$. Statins were dissolved in DMSO and were added at different concentrations directly into the medium covering the cells. In case an inhibitor study was performed, indocyanine green ICG $(10 \mu \mathrm{M})$ or E3S $(300 \mu \mathrm{M})$ were added one hour before statin treatment. After $24 \mathrm{~h}, 48 \mathrm{~h}$ or $72 \mathrm{~h}$ alamarBlue ${ }^{\circledR}$ solution was added (10\% percent of total volume) to every well and incubated for $4 \mathrm{~h}$ to $6 \mathrm{~h}$ at $37^{\circ} \mathrm{C}$ and $5 \% \mathrm{CO}_{2}$. Fluorescence was measured using the plate reader "Twinkle LB970 (Berthold Technologies, Bad Wildbad, Germany) with excitation wavelength at $560 \mathrm{~nm}$ and emission wavelength at $590 \mathrm{~nm}$. $\mathrm{IC}_{50}$-values were calculated using a four parameter logistic nonlinear regression model.

\subsubsection{Confocal laser scanning microscopy (CLSM)}

Cells were seeded on sterile cover slips in 6-well plates at a density of 100,000 cells / well and incubated at $37^{\circ} \mathrm{C}$ and $5 \% \mathrm{CO}_{2}$ until confluency and treated with or without $\mathrm{NaB}(5 \mathrm{mM}) 24 \mathrm{~h}$ prior the cells were confluent. Medium was replaced with fixation solution containing $4 \%(\mathrm{w} / \mathrm{v})$ paraformaldehyde and $0.5 \%$, $0.75 \%$, or $1 \%(\mathrm{w} / \mathrm{v})$ Triton $\mathrm{X}-100$ in phosphate buffer. Phosphate buffer was prepared by mixing $200 \mathrm{mM} \mathrm{Na}_{2} \mathrm{HPO}_{4}$ and $200 \mathrm{mM} \mathrm{NaH} \mathrm{PO}_{4}$ until pH7.4 was reached. Cells were fixed for $1 \mathrm{~h}$ at RT. Fixation solution was aspirated and cover slips were washed three times with PBS. Afterwards cover slips were incubated consecutively with $0.25 \%(\mathrm{w} / \mathrm{v}) \mathrm{NH}_{4} \mathrm{Cl}$ in PBS for $5 \mathrm{~min}, 0.1 \%(\mathrm{w} / \mathrm{v})$ saponin in PBS for $10 \mathrm{~min}, 0.1 \%(\mathrm{w} / \mathrm{v})$ saponin and $2 \%(\mathrm{w} / \mathrm{v})$ gelatin in PBS for $30 \mathrm{~min}$, $0.1 \%(\mathrm{w} / \mathrm{v})$ saponin in PBS for $10 \mathrm{~min}$ twice, and finally $0.1 \%$ saponin $(\mathrm{w} / \mathrm{v})$ and $1 \%(\mathrm{w} / \mathrm{v})$ BSA in PBS for $10 \mathrm{~min}$. Cover slips were transferred to a humid chamber lined with parafilm, and $150 \mu$ l of primary antibody was added dropwise at different concentrations. The incubation lasts for $2 \mathrm{~h}$ at RT or overnight at $4^{\circ} \mathrm{C}$. Cover slips were washed three times with $0.1 \%$ saponin $(\mathrm{w} / \mathrm{v})$ and $1 \%$ $(\mathrm{w} / \mathrm{v})$ BSA in PBS. The secondary antibody Alexa Fluor ${ }^{\circledR} 488$ goat anti-rabbit IgG was applied at different concentrations for $1 \mathrm{~h}$ at RT in a humid chamber in the dark. Primary and secondary antibodies were diluted in $0.1 \%$ Saponin $(\mathrm{w} / \mathrm{v})$ and $1 \%(\mathrm{w} / \mathrm{v})$ BSA in PBS. 


\subsubsection{Apoptosis assessed by measuring caspase-3 activity}

To measure caspase-3 activity, a caspase-3-specific substrate coupled to a fluorophore was used, in this case Ac-DEVD-AMC (Asp-Glu-Val-Asp 7-amido-4-methylcoumarin). This substrate consists of a peptide sequence [Asp-Glu-ValAsp (DEVD)] which is specifically recognized by caspase-3. DEVD is coupled to the fluorophore 7-amido-4-methylcoumarin (AMC) and is cleaved of by hydrolysis of caspase- 3 upon binding. The released AMC is directly proportional the amount of active caspase-3 [86,87]. To assess caspase- 3 activity, cells were seeded at a density of 10,000 cells per well into white 96-well microplate with Clear Bottom (ViewPlate-96, PerkinElmer ${ }^{\circledR}$ ). Plates were incubated for $48 \mathrm{~h}$ at $37^{\circ} \mathrm{C}, 5 \% \mathrm{CO}_{2}$ in humidified incubator. Medium was removed by inverting the plates and replaced with medium containing statins at the given concentrations. Cells were incubated up to $6 \mathrm{~h}$ at $37^{\circ} \mathrm{C}, 5 \% \mathrm{CO}_{2}$ in humidified incubator. Medium was removed by shaking of and cells were washed twice with PBS. Afterwards, cells were lysed in $60 \mu \mathrm{l}$ ice cold lysis buffer $(120 \mathrm{mM} \mathrm{NaCl}, 5 \mathrm{mM}$ EDTA, 0.5\% NP-40 and $25 \mathrm{mM}$ Tris-HCl, pH 8) diluted 1:2 in PBS and incubated for $10 \mathrm{~min}$ at $37^{\circ} \mathrm{C}$. Lysed cells were homogenized by pipetting 15 times up and down. An aliquot of $10 \mu \mathrm{l}$ was transferred to a new 96-well plate for protein determination. Lysed cells were mixed with $50 \mu \mathrm{l}$ of $12.5 \mu \mathrm{M}$ Ac-DEVD-AMC (dissolved in PBS) and incubated for $1 \mathrm{~h}$ at $37^{\circ} \mathrm{C}$. Fluorescent signal was read at excitation of $365 \mathrm{~nm}$ and emission of 410-460 $\mathrm{nm}$ using GloMax ${ }^{\circledR}-\mathrm{Multi}+\mathrm{Mi}-$ croplate Multimode Reader with Instinct ${ }^{\circledR}$ software (Promega ${ }^{\circledR}$, Zurich, CH). 



\section{Results}

\subsection{Statin toxicity in non-muscle cell lines}

To investigate the toxic potential of statins in non-muscle cells, the fibroblast cell line $\mathrm{CHO}$ expressing different OATPs was used. These cell lines were formerly transfected to express OATP1B1, or 1B3, or 2B1 [61, 80]. To asses statin toxicity, cells were treated with increasing concentrations of the lipophilic cerivastatin, simvastatin, or atorvastatin and the hydrophilic pravastatin or rosuvastatin for $72 \mathrm{~h}$. Cell viability was measured using alamarBlue ${ }^{\circledR}$. The results presented in Fig. 4 indicate that lipophilic statins are more toxic (lower $\mathrm{IC}_{50}$ ) compared to hydrophilic statins, with cerivastatin showing the strongest toxic effect (lowest $\mathrm{IC}_{50}$ ), while pravastatin appeared to be the least toxic statin. For the latter, cells start to die first in the mM-range (Fig. 4). $\mathrm{IC}_{50}$ values between the different cell lines did not differ significantly for all the statins tested (Tab.5).

\begin{tabular}{|c|c|c|c|c|}
\hline $\mathrm{IC}_{50}$ values $[\mu \mathrm{M}]$ & CHO WT & CHO 1B1 & $\mathrm{CHO} 1 \mathrm{~B} 3$ & $\mathrm{CHO} 2 \mathrm{~B} 1$ \\
\hline Cerivastatin & 0.81 & 0.71 & 1.10 & 1.70 \\
\hline Simvastatin & 1.44 & 2.08 & 7.85 & 10.81 \\
\hline Atorvastatin & 37.59 & 17.01 & 34.97 & 42.95 \\
\hline Rosuvastatin & 69.43 & $\begin{array}{c}\text { no } \\
\text { inhibition }\end{array}$ & 1147.00 & 157.40 \\
\hline Pravastatin & $\begin{array}{c}\text { no } \\
\text { inhibition }\end{array}$ & $\begin{array}{c}\text { no } \\
\text { inhibition }\end{array}$ & $\begin{array}{c}\text { no } \\
\text { inhibition }\end{array}$ & $\begin{array}{c}\text { no } \\
\text { inhibition }\end{array}$ \\
\hline
\end{tabular}

Tab. 5: $\mathrm{IC}_{50}$ values of cell viability assay. Cells were treated with the indicated statins for $72 \mathrm{~h}$. $\mathrm{IC}_{50}$ values were calculated using a four parameter logistic nonlinear regression model. 

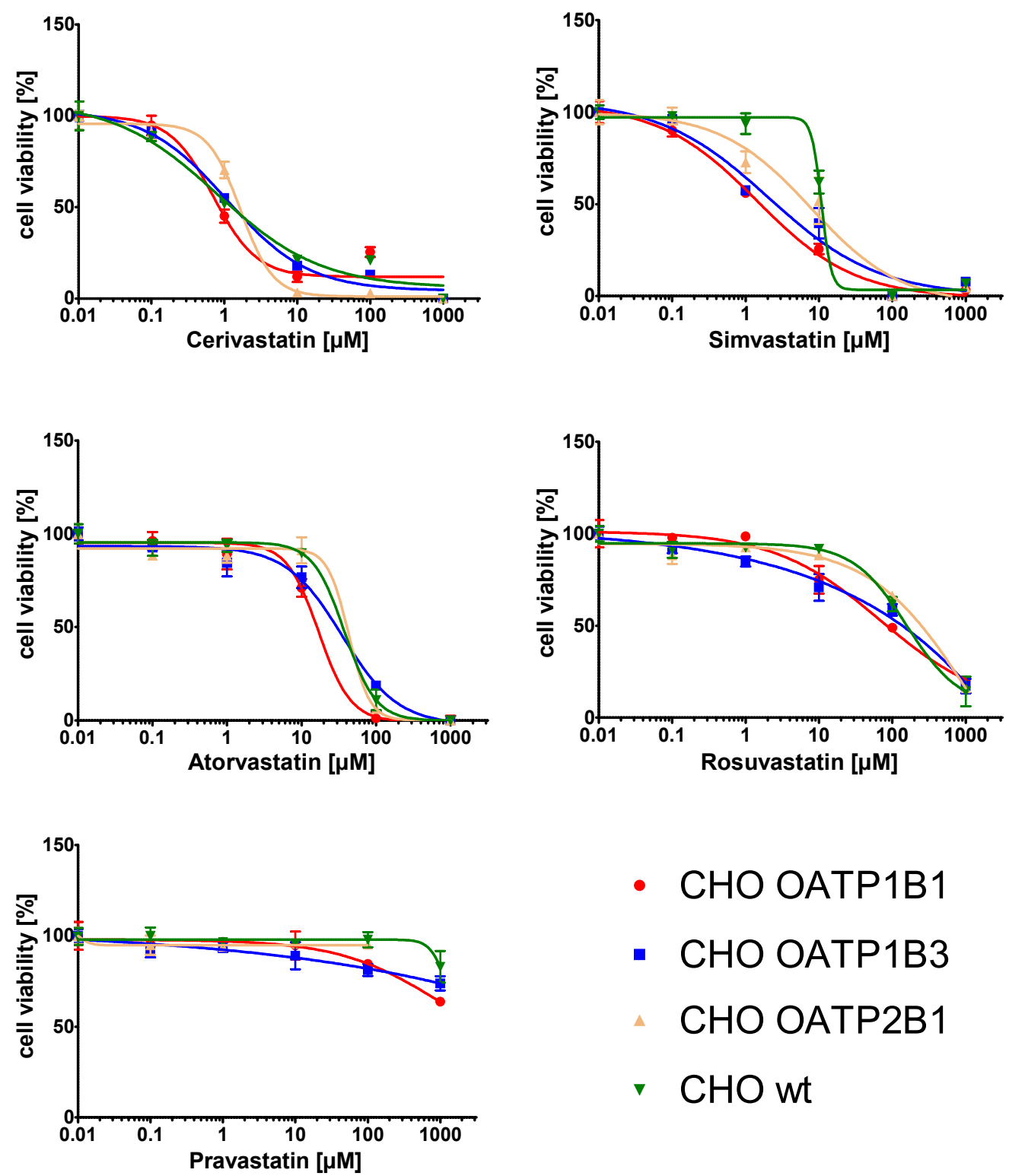

- $\mathrm{CHO}$ OATP1B1

- CHO OATP1B3

CHO OATP2B1

- $\mathrm{CHO}$ wt

Fig. 4: Analysis of cell viability assay after statin treatment.

$\mathrm{CHO}$ cells Expressing OATP1B1, or -1B3, or -2B1 and control cells (wt) were treated with increasing concentrations of the indicated statin over $72 \mathrm{~h}$ and viability was determined as described in materials and methods. Each data point represents the mean \pm S.D. (standard deviation) of three replicates.

\subsection{Statin toxicity in non-muscle cell lines compared to muscle cells}

To investigate whether muscle cells (L6 and C2C12) show a distinct pattern of susceptibility after statin treatment compared to the fibroblast cell line $\mathrm{CHO}$, 
cells were incubated for $72 \mathrm{~h}$ with increasing concentrations of lipophilic cerivastatin und hydrophilic pravastatin. Cell viability was then determined with alamarBlue ${ }^{\circledR}$. Results indicate that muscle cells are indeed more susceptible to statins when compared with the non-muscle cell line CHO. Interestingly, pravastatin shows toxicity in L6 cells already at low $\mu \mathrm{M}$-concentrations, which is not the case for $\mathrm{C} 2 \mathrm{C} 12$, where pravastatin appeared to be toxic at concentrations higher than $100 \mu \mathrm{M}$ (Fig. 5).
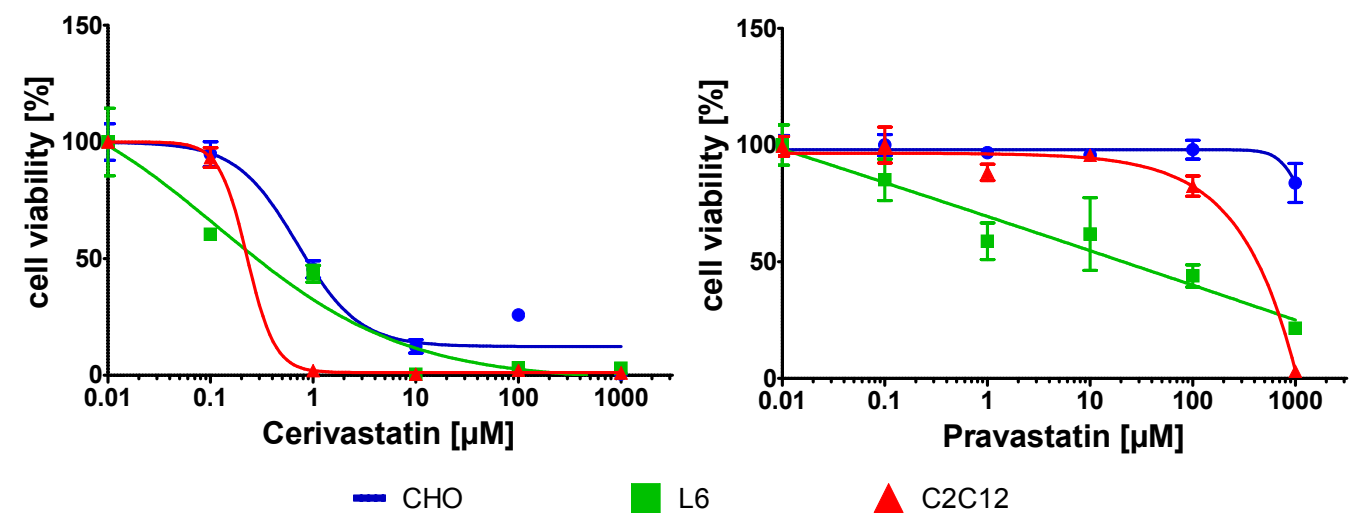

Fig. 5: Analysis of cell viability assay after $72 \mathrm{~h}$ statin treatment.

L6, C2C12 and CHO-cells were treated with increasing concentrations of cerivastatin (left) or pravastatin (right) over $72 \mathrm{~h}$. Each data point represents the mean \pm S.D. of three replicates.

$\mathrm{IC}_{50}$ values indicate that muscle cells are more sensitive against the lipophilic cerivastatin compared to the non-muscle fibroblast cell line $\mathrm{CHO}$ (Tab. 6). Comparing the muscle cells, C2C12 cells were less susceptible than L6 against cerivastatin. For pravastatin it was not possible to calculate $\mathrm{IC}_{50}$ values from the data points obtained. However, this experiment demonstrated that muscle cells are more sensitive towards cerivastatin and pravastatin than $\mathrm{CHO}$ cells.

\begin{tabular}{|c|c|c|c|c|c|c|}
\hline \multirow{2}{*}{} & \multicolumn{2}{|c|}{$\mathrm{CHO}$} & \multicolumn{2}{c|}{ C2C12 } & \multicolumn{2}{c|}{ L6 } \\
\cline { 2 - 7 } & $\mathrm{IC}_{50}[\mu \mathrm{M}]$ & $\begin{array}{c}95 \% \text { conf. } \\
\text { interval }\end{array}$ & $\mathrm{IC}_{50}[\mu \mathrm{M}]$ & $\begin{array}{c}95 \% \text { conf. } \\
\text { interval }\end{array}$ & $\mathrm{IC}_{50}[\mu \mathrm{M}]$ & $\begin{array}{c}95 \% \text { conf. } \\
\text { interval }\end{array}$ \\
\hline Cerivastatin & 0.71 & $\begin{array}{c}0.04 \\
\text { to } \\
10.46\end{array}$ & 0.23 & $\begin{array}{c}0.13 \\
\text { to } \\
0.41\end{array}$ & 0.12 & $\begin{array}{c}6.14 \cdot 10^{-7} \\
\text { to } \\
2.30 \cdot 10^{4}\end{array}$ \\
\hline
\end{tabular}

Tab. 6: $\log \mathrm{IC}_{50}$ values and $95 \%$ confidence intervals of the $\log \mathrm{IC}_{50}$ values. Cells were incubated for $72 \mathrm{~h}$ with cerivastatin. 


\subsection{Transfection of $\mathrm{L} 6$ and $\mathrm{C} 2 \mathrm{C} 12$ cells}

\subsubsection{Killing curve}

To determine the concentration of G-418 required for killing all L6 and C2C12 wt cells, a cell survival assay was performed. Therefore, cells were treated with increasing concentrations of G-418. After eleven days cell viability was measured using the alamarBlue ${ }^{\circledR}$ assay. The lowest concentration of G-418 killing $100 \%$ of the wild type cells was chosen to treat cells after transfection. The killing curve is shown in Fig. 6. $\mathrm{IC}_{50}$ of G-418 was $403 \mu \mathrm{g} / \mathrm{ml}$ and $557 \mu \mathrm{g} / \mathrm{ml}$ for L6 and C2C12 cells, respectively. After transfection, $1 \mathrm{mg} / \mathrm{ml}$ of G-418 was used to select successfully transfected cells, as this concentration was the lowest to kill all cells after eleven days of G-418 treatment.

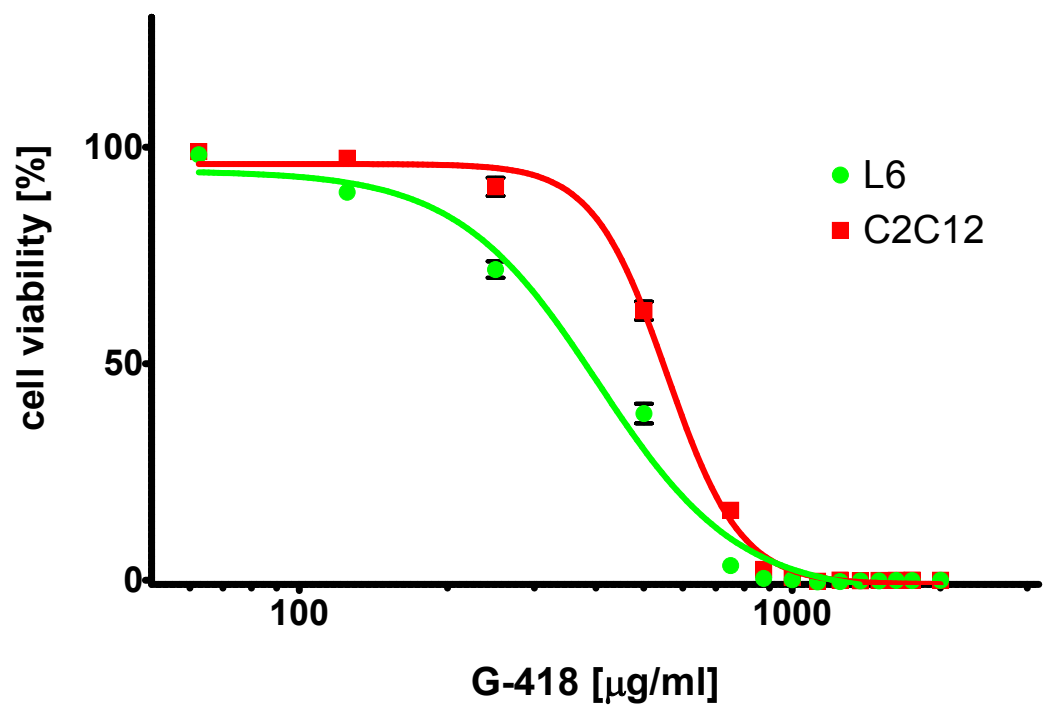

Fig. 6: Killing curve

C2C12 and L6 cells treated with increasing concentrations of G-418 (Geneticin) for 11 days to establish a killing curve. Each data point represents the mean \pm S.D. of three replicates.

\subsubsection{Transfection with OATP1B1 and OATP1B3 in pIRESneo2 vector}

Plasmids of OATP1B1 and -1B3 in pIRESneo2 vector were already available in the lab [61]. After sequencing, plasmids were amplified and purified for 
transfection. To enhance the chance of proper insertion into genomic DNA of the target cells, plasmids were linearized by restriction digestion. Samples of the plasmids were separated with an agarose gel to check proper linearization. Fig. 7 shows samples of the linearized plasmids (lane $1 \& 3$ ) and the undigested controls (lane $2 \& 4$ )

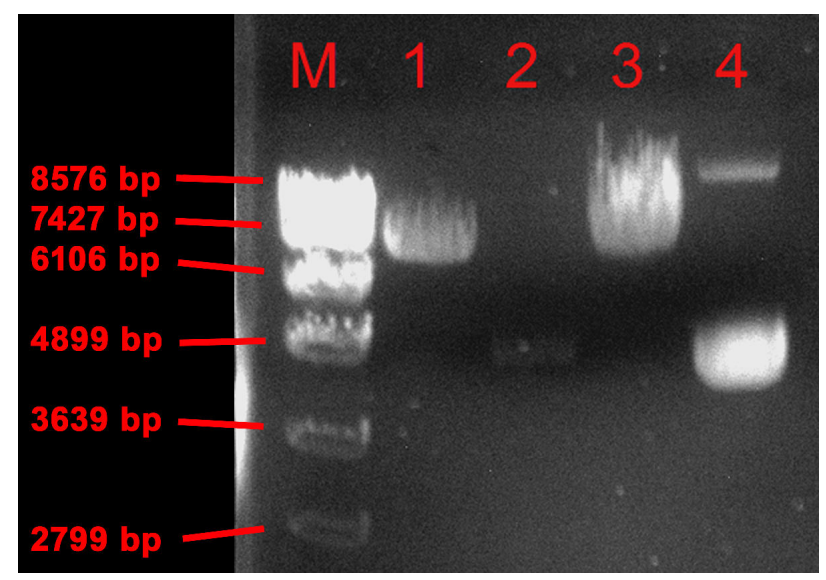

Fig. 7: Linearization of plasmids

M: DNA Marker VII (Roche, Basel, $\mathrm{CH}$ ), 1: OATP1B1 linearized, 2: OATP1B1 undigested, 3: OATP1B3 linearized, 4: OATP1B3 undigested

For transfecting cells, a chemical method using FuGENE and a physical method, electroporation, were used. For the latter different settings of voltage and capacitance were tried, but none of the tested settings resulted in surviving cells. As both transfection methods where done in parallel and chemical transfection resulted in surviving cells, electroporation method was not further optimized. For transfecting cells with FuGENE different ratios of FuGENE to DNA were used, as this ratio can have an influence on the efficacy of transfection [88]. This FuGENE to DNA ratio is always part of the name of the respective clone. After $24 \mathrm{~h}$, transfected cells were put under selection pressure by adding G-418 $(1 \mathrm{mg} / \mathrm{ml})$ to the culture medium. As soon as cells recovered and reached $80-90 \%$ confluency, a limiting dilution cloning assay was performed to obtain a monoclonal cell population starting from a polyclonal mass of cells. Pools of cells, which recovered from transfection are indicated below (Tab.7, shaded in blue). The limiting dilution cloning assay resulted in 120 clones which were subsequently tested for their capacity to transport prototypical OATP substrates.

Previous experience in the laboratory had shown that directly screening for functional active clones can successfully speed-up the process of finding a proper 


\begin{tabular}{|c|c|c|c|c|}
\hline Cell line & Transporter & \multicolumn{3}{|c|}{ Fugene:DNA ratio } \\
\hline \multirow{2}{*}{ L6 } & OATP1B1 & $5: 2$ & $7: 2$ & $9: 2$ \\
\cline { 2 - 5 } & OATP1B3 & $5: 2$ & $7: 2$ & $9: 2$ \\
\hline \multirow{2}{*}{ C2C12 } & OATP1B1 & $5: 2$ & $7: 2$ & $9: 2$ \\
\cline { 2 - 5 } & OATP1B3 & $5: 2$ & $7: 2$ & $9: 2$ \\
\hline
\end{tabular}

Tab. 7: Conditions used for limited dilution cloning assay are shaded in blue.

clone [61]. Therefore, clones were directly screened for functional transport using a cellular uptake assay with tritium labeled E3S, which is a known substrate of OATP1B1 and OATP1B3 [89]. For screening, cells were grown on $3 \mathrm{~cm}$ culture dishes incubated for $5 \mathrm{~min}$ with uptake solution at $37^{\circ} \mathrm{C}$. To calculate nonspecific binding of substrate to the plasma membrane, another set of cells was flushed with ice-cold uptake solution representing the zero value $(0 \mathrm{~min}$, $4^{\circ} \mathrm{C}$ ). Net uptake values were obtained by subtracting uptake at $4^{\circ} \mathrm{C}$ from total uptake at $37^{\circ} \mathrm{C}$. The number of clones tested is listed in Tab. 8 .

\begin{tabular}{|c|c|c|c|}
\hline Cell line & Transporter & $\begin{array}{c}\text { Fugene:DNA } \\
\text { ratio }\end{array}$ & $\begin{array}{c}\text { \# clones tested } \\
\text { for transport }\end{array}$ \\
\hline \multirow{3}{*}{ L6 } & \multirow{2}{*}{ OATP1B1 } & $5: 2$ & 20 \\
\cline { 3 - 4 } & & $9: 2$ & 7 \\
\cline { 2 - 4 } & OATP1B3 & $9: 2$ & 10 \\
\hline \multirow{3}{*}{ C2C12 } & OATP1B1 & $9: 2$ & 15 \\
\cline { 2 - 4 } & \multirow{2}{*}{ OATP1B3 } & $5: 2$ & 27 \\
\cline { 3 - 4 } & & $9: 2$ & 17 \\
\hline
\end{tabular}

Tab. 8: Amount of clones tested for transport with the OATP1B1 and -1B3 substrate estrone-3-sulfate.

Of the transfected L6 cells, none of the tested clones showed a difference of two-fold transport rate compared to the wild type cells. This threshold should allow selecting clones, which express an amount of transport protein amenable to detection by protein methods like e.g. Western blotting. Result of screening for some of the tested clones is shown in Fig. 8. Therefore, transfection was repeated with the same conditions as listed in Tab. 7. The results of the second transfection of L6 cells is described later.

In contrast, after transfecting the $\mathrm{C} 2 \mathrm{C} 12$ cell line, about 6 clones per gene displayed specific uptake of E3S. The clones with the highest transport rates were then tested again together in the same uptake experiment. Therefore, the cells 


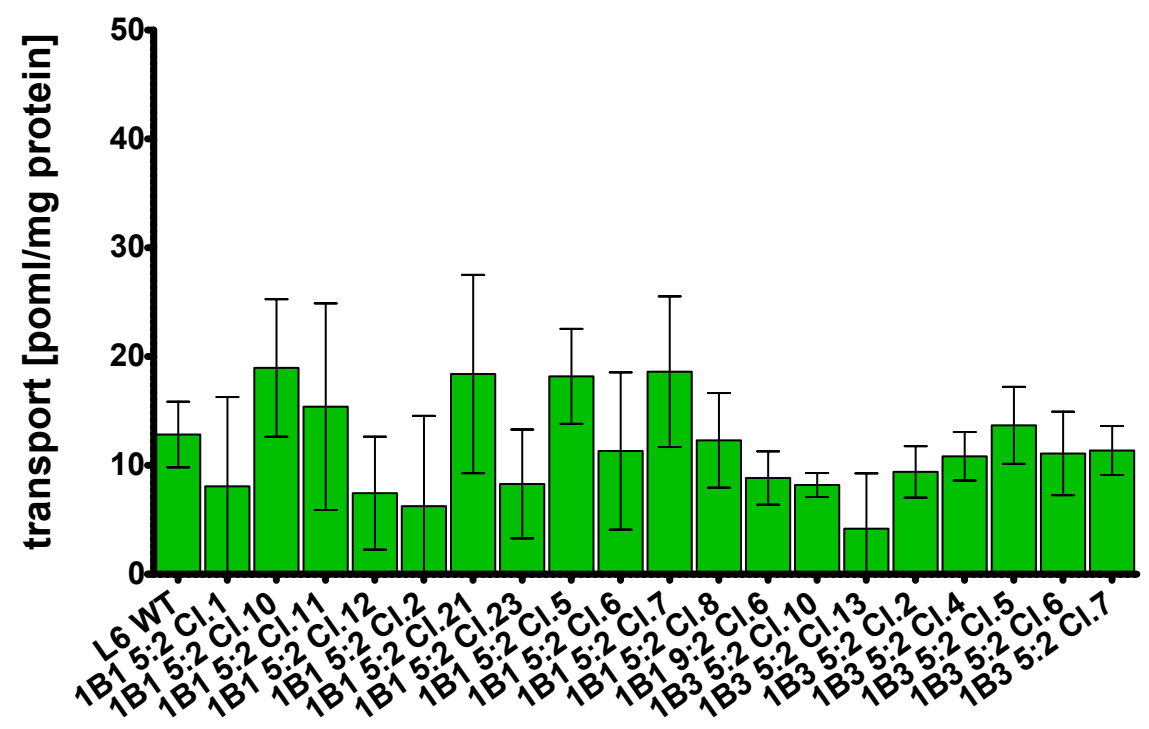

Fig. 8: Cellular uptake of ${ }^{3} \mathrm{H}$-estrone-3-sulfate $(5 \mu \mathrm{M})$ after $5 \mathrm{~min}$.

L6 clones transfected with OATP1B1 or -1B3 cDNA where tested for uptake of estrone-3-sulfate after single cell cloning. Data show net uptake values calculated by subtraction of zero value from 5 min time point. Each bar represents the mean \pm S.D. of three replicates.

were incubated for 5 min with uptake solution containing E3S $(5 \mu \mathrm{M})$ as substrate (Fig. 9). From this experiment, it was decided to focus on clones expressing OATP1B1, as clones expressing OATP1B3 did not reproducibly show an at least twofold transport rate compared to the wild type. To further narrow down the amount of clones, three clones expressing OATP1B1 were tested, namely C2C12 OATP1B1 clone 1, 6, and 7 (all 9:2), at one and 5 min (Fig. 10). Clone 1 was included here, because it showed transport in an earlier experiment (data not shown).

After this experiment, the work was proceeded with C2C12 OATP1B1, 9:2, Clone 6 hereinafter called C2C12 1B1. To characterize this clone, a time course experiment was conducted to follow the transport over time (Fig. 11). Cells were incubated for $30 \mathrm{~s}, 1 \mathrm{~min}, 2 \mathrm{~min}$, and $5 \mathrm{~min}$ with E3S $(5 \mu \mathrm{M})$. Fig. 11 shows that uptake of the standard OATP1B1 substrate E3S is steadily increased up to $5 \mathrm{~min}$ and largely exceeded the uptake into the non-transfected parent cell line.

Myoblasts are precursor cells of the final muscle tissue in vivo. They need to fuse for building multi-nucleated muscle cells, which are subsequently able to mature into various classes of myofibers [90]. To differentiate myoblasts in vitro into long and multinuclear myotubes, they are cultured under a low level of 


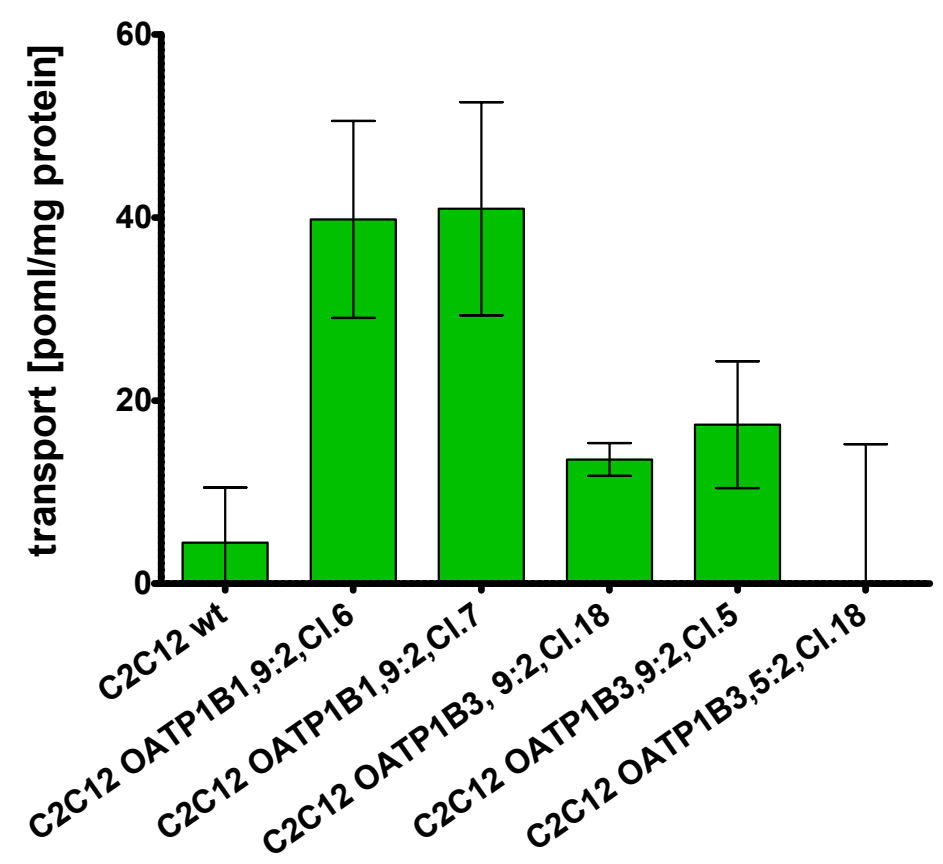

Fig. 9: Cellular uptake of ${ }^{3} \mathrm{H}$-estrone-3-sulfate $(5 \mu \mathrm{M})$ after $5 \mathrm{~min}$.

Clones transfected with OATP1B1 or OATP1B3 cDNA where tested for uptake of estrone-3-sulfate. Data show net uptake values calculated by subtraction of zero value from $5 \mathrm{~min}$ time point. Each bar represents the mean \pm S.D. of three replicates.

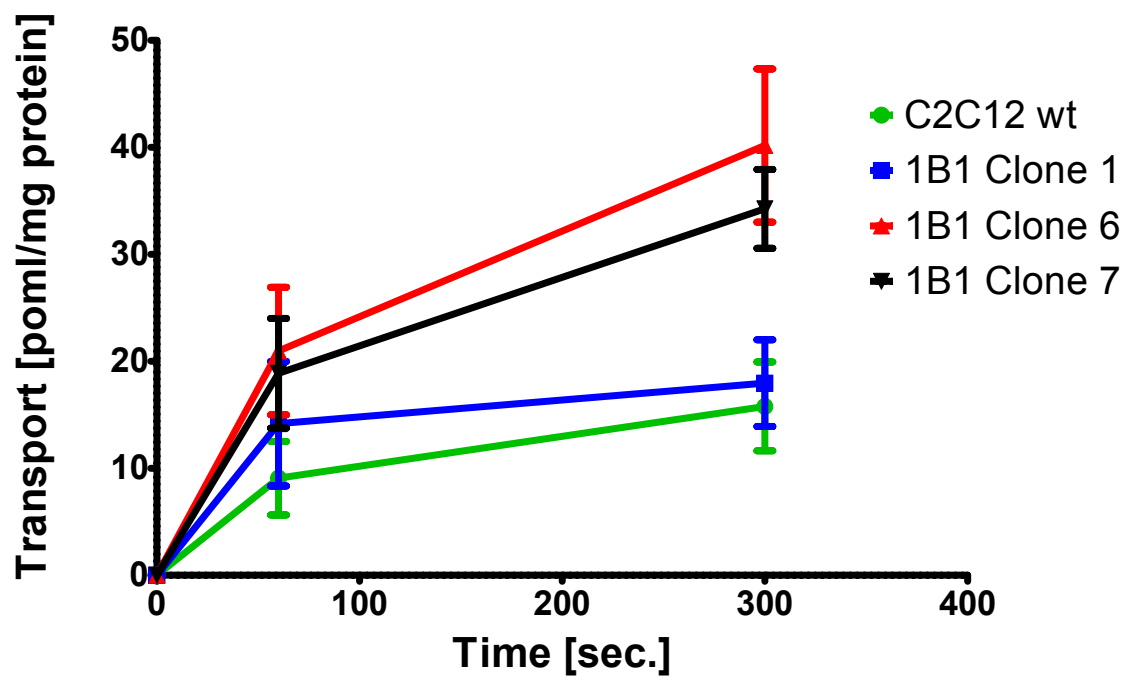

Fig. 10: Cellular uptake of ${ }^{3} \mathrm{H}$-estrone-3-sulfate $(5 \mu \mathrm{M})$ in $\mathrm{C} 2 \mathrm{C} 12$ cells.

C2C12 wild type cells (wt) and three clones expressing OATP1B1 (1B1) were tested for estrone-3-sulfate at $1 \mathrm{~min}$ and $5 \mathrm{~min}$. Data show net uptake values calculated by subtraction of zero value. Each data point represents the mean \pm S.D. of three replicates.

growth factors. Instead of using 10\% FCS like in normal subcultivation, the medium contained $2 \%$ horse serum [76]. As C2C12 myotubes are closer to the 


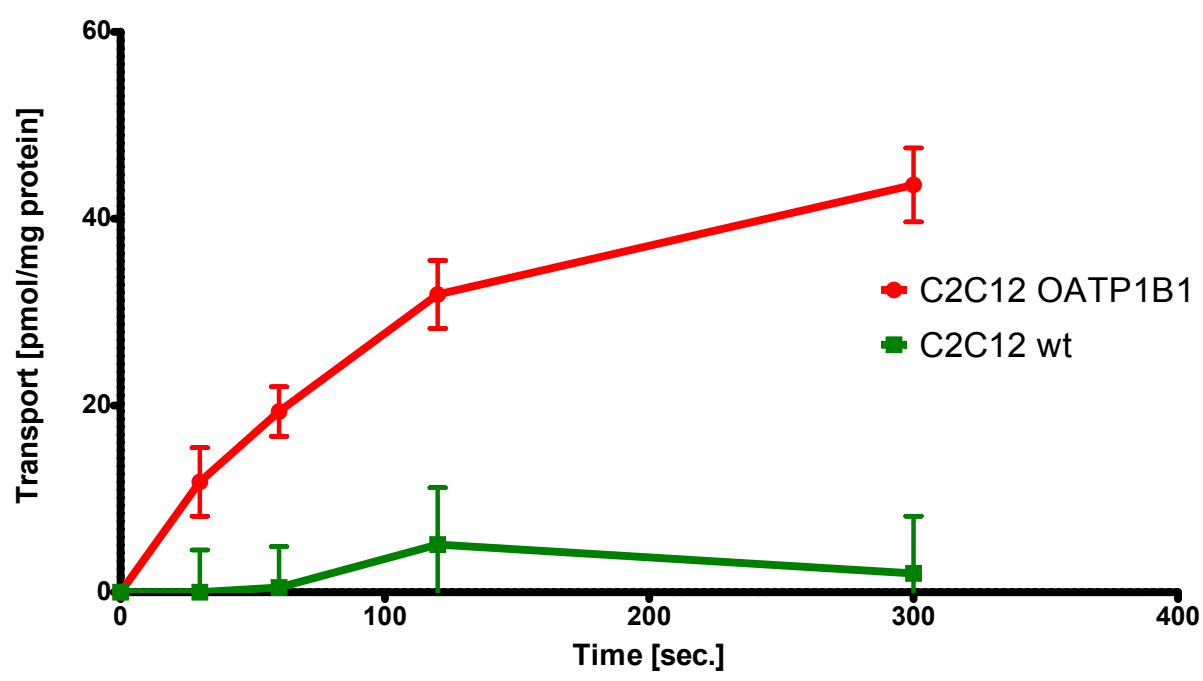

Fig. 11: Transport of ${ }^{3} \mathrm{H}$-E3S $(5 \mu \mathrm{M})$ over time.

Transport into C2C12 OATP1B1 (red) and C2C12 wild type (green) cells. Data show net uptake values calculated by subtraction of zero value. Each data point represents the mean \pm S.D. of three replicates.

in vivo myofibers than myoblasts are, they may provide a better model of the in vivo situations. Therefore, it was tried to differentiate cells of the clone into myotubes by treating $\mathrm{C} 2 \mathrm{C} 12 \mathrm{wt}$ and $\mathrm{C} 2 \mathrm{C} 12$ 1B1 cells with differentiation medium for 5-10 days. The wild type cells already formed myotubes after 3-4 days while the selected clone did not, even after eleven days (Fig. 12). In contrast, cells of this clone are still able to fuse, shown in Fig. 13, but they do not form long myotubes in large numbers as the wild type cells do. Instead, the rarly form roundish, huge cells harboring several cell nuclei. Therefore, all subsequent investigations were performed with myoblasts.

\subsection{Uptake of statins}

After having identified a clone showing proper transport of the OATP1B1 model substrate E3S, uptake of different statins by this clone was tested and compared to the OATP-transfected $\mathrm{CHO}$ cells. Cells were incubated with radioactively labeled pravastatin, simvastatin, cerivastatin or E3S at $5 \mu \mathrm{M}$ for $3 \mathrm{~min}$, whereby the latter substrate served as assay control. CHO OATP1B1 transfected served as positive control. The results (Fig. 14) demonstrate that E3S and pravastatin are taken up into the CHO OATP1B1 cells proving the success of this assay. C2C12 1B1 cells are also taking up E3S and pravastatin, proving that these 


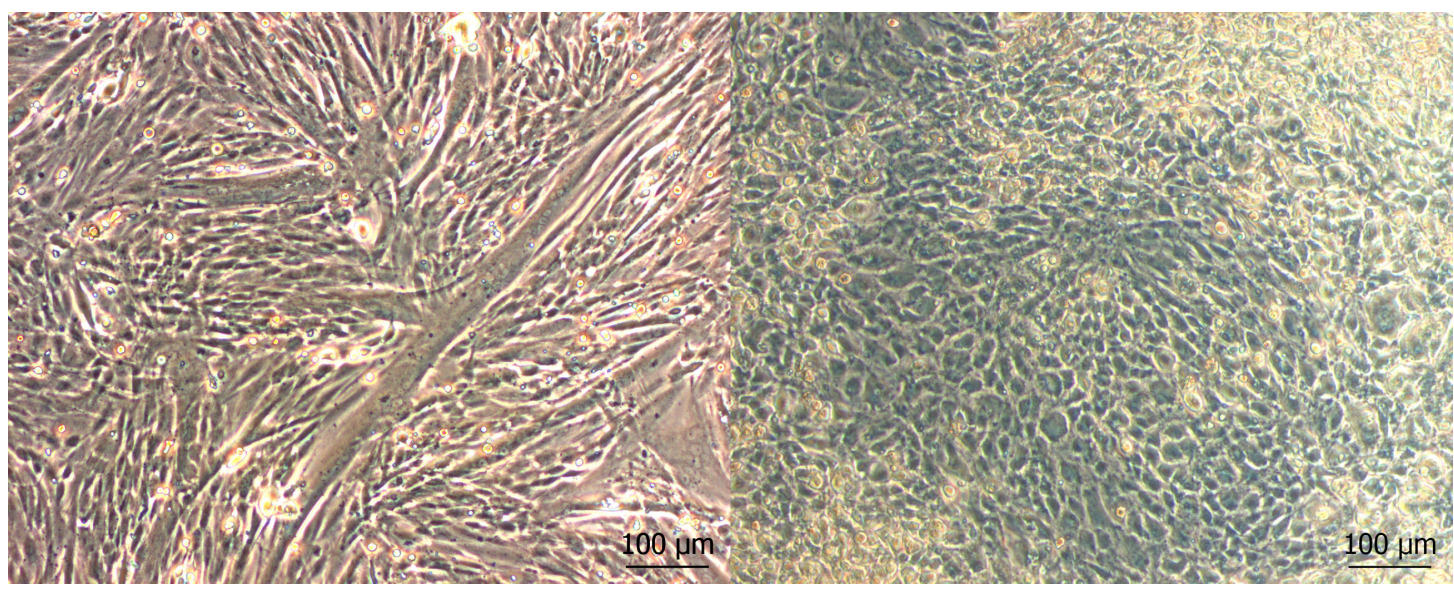

Fig. 12: Differentiation of muscle cells.

C2C12 wild type cell (left) and C2C12 OATP1B1 (right) cells were treated with differentiation medium for 11 days to form multi-nucleated myotubes.

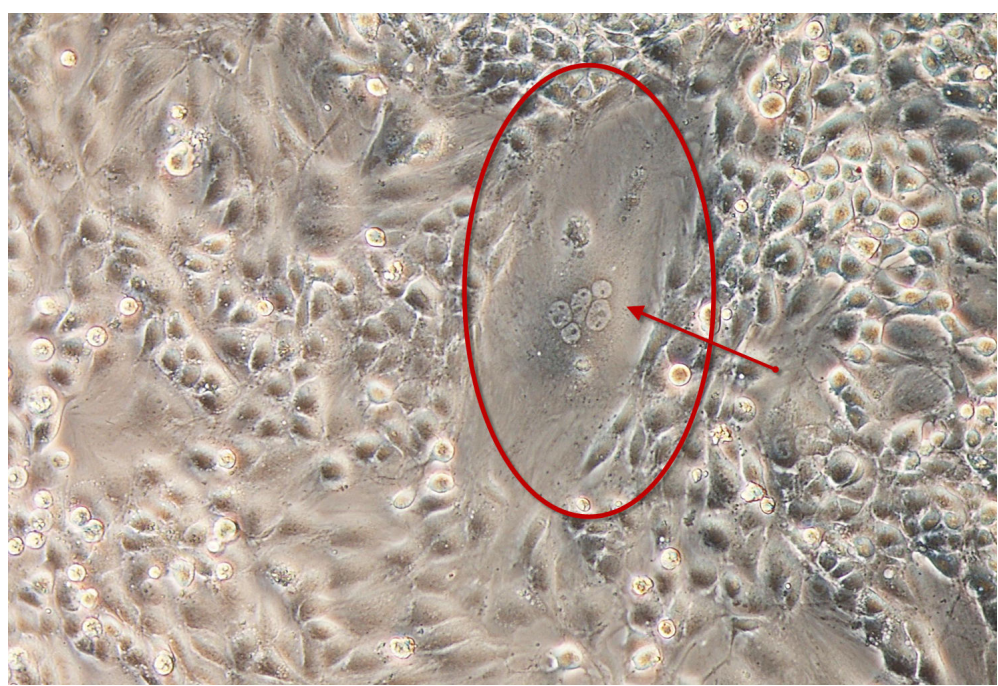

Fig. 13: Differentiated C2C12 OATP1B1 cells.

Cells were treated for 10 days with differentiation medium. Cells of this clone are still able to fuse, shown by multi nucleated cells (red arrow), but do not form long myotubes in large amounts.

cells express a functional statin transporter. Interestingly, the uptake values for cerivastatin and for simvastatin are at least one order and two orders of magnitude higher, respectively, when compared to E3S. For simvastatin there is no difference in uptake when comparing transfected and parent cell line, applicable for $\mathrm{CHO}$ cells as well as for $\mathrm{C} 2 \mathrm{C} 12$ cells. A slightly higher uptake of cerivastatin was observable for CHO OATP1B1 cells compared to the nontransfected control. This effect is not apparent in C2C12 cells. With this test it was possible to demonstrate that $\mathrm{C} 2 \mathrm{C} 121 \mathrm{~B} 1$ cells express a functionally active statin transporter. 

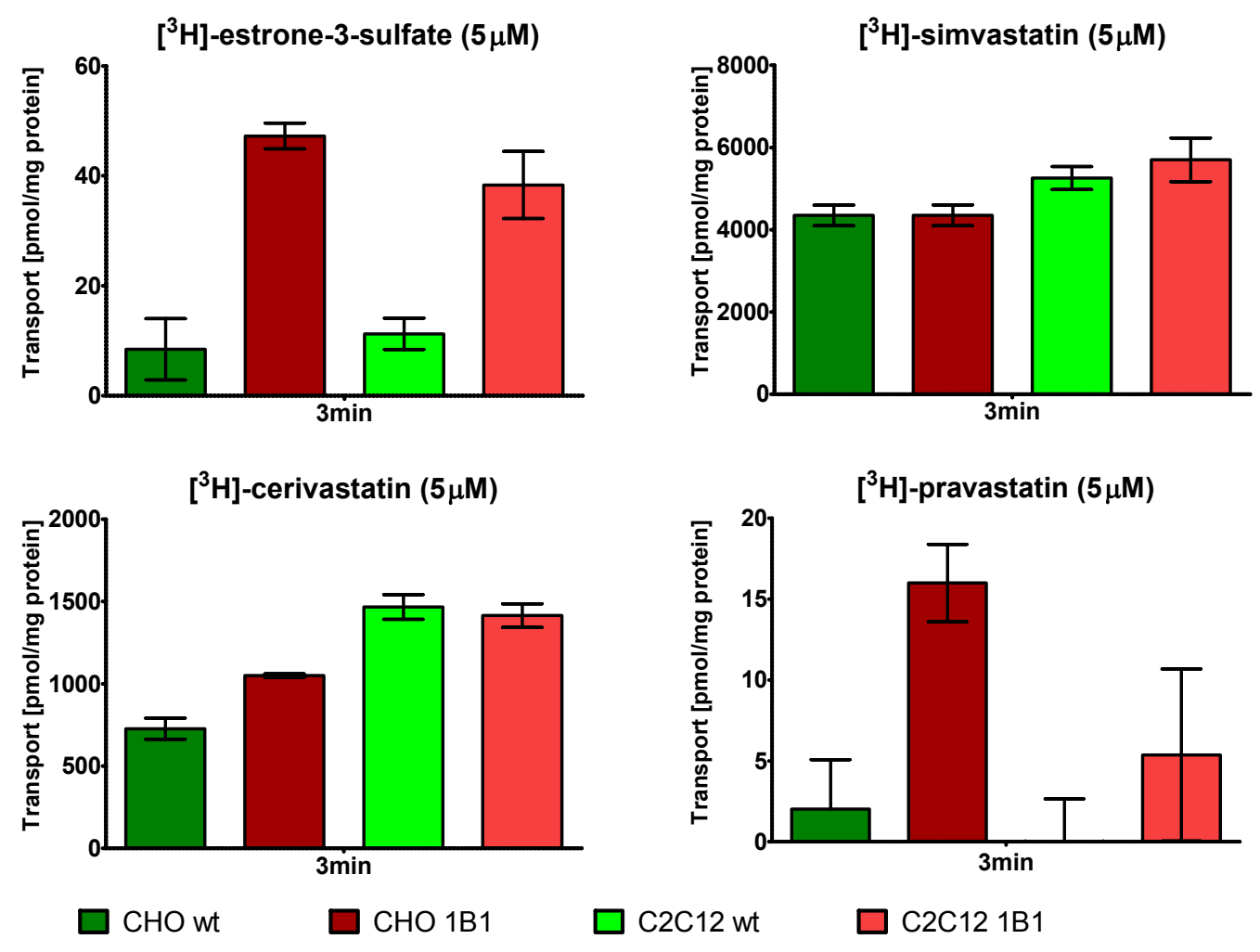

Fig. 14: Analysis of uptake assay with different statins as substrate.

$\mathrm{CHO}$ and $\mathrm{C} 2 \mathrm{C} 12$ cells were incubated for 3 min with $5 \mu \mathrm{M}$ of E3S, pravastatin, simvastatin or cerivastatin. Data show net uptake values calculated by subtraction of zero value. Each data point represents the mean \pm S.D. of three replicates.

It is well established that transport activity of OATPs/Oatps is stimulated by an acidic extracellular environment $([64,65]$. Nozawa et al. demonstrated that HEK cells expressing OATP2B1 transport pravastatin to a greater extent at $\mathrm{pH} 5.0$ compared to $\mathrm{pH} 7.4$ [64]. Muscle cells exhibit a lower $\mathrm{pH}$ compared to other tissues or blood. Carter et al. showed that intracellular $\mathrm{pH}$ in rat skeletal muscle cells is about 6.0, but the evidence for this is controversial [91]. To test the hypothesis whether statins show higher uptake under low extracellular $\mathrm{pH}$ conditions, transport experiments with different statins were performed at slightly acidic conditions ( $\mathrm{pH} 6.5$ ) and under physiological conditions ( $\mathrm{pH} 7.4$ ). Therefore, C2C12 wt cells and C2C12 1B1 cells were incubated with uptake solution (pH6.5 or pH7.4) including $5 \mu \mathrm{M}$ of E3S, pravastatin, simvastatin, or cerivastatin for $3 \mathrm{~min}$. The results in Fig. 15 show that uptake of E3S at pH 6.5 was decreased in C2C12 1B1 compared to pH7.4. Still, the transfected cell line showed higher uptake compared to the control cells. Pravastatin uptake was increased 
in $\mathrm{C} 2 \mathrm{C} 12$ 1B1 and control cells. Here, no difference was observed in the uptake by transfected and wild type cells. For simvastatin, the $\mathrm{pH}$ seems to have no influence at all, as uptake values at pH6.5 are similar to those at $\mathrm{pH} 7.4$. Additionally, similar differences were observed in uptake between C2C12 1B1 and control cells at pH6.5 \& pH7.4 respectively. For cerivastatin, uptake was approximately twofold higer at $\mathrm{pH} 6.5$ for transfected and control cells, with C2C12 1B1 showing higher uptake than the wild type cells, which was not the same as at $\mathrm{pH} 7.4$.
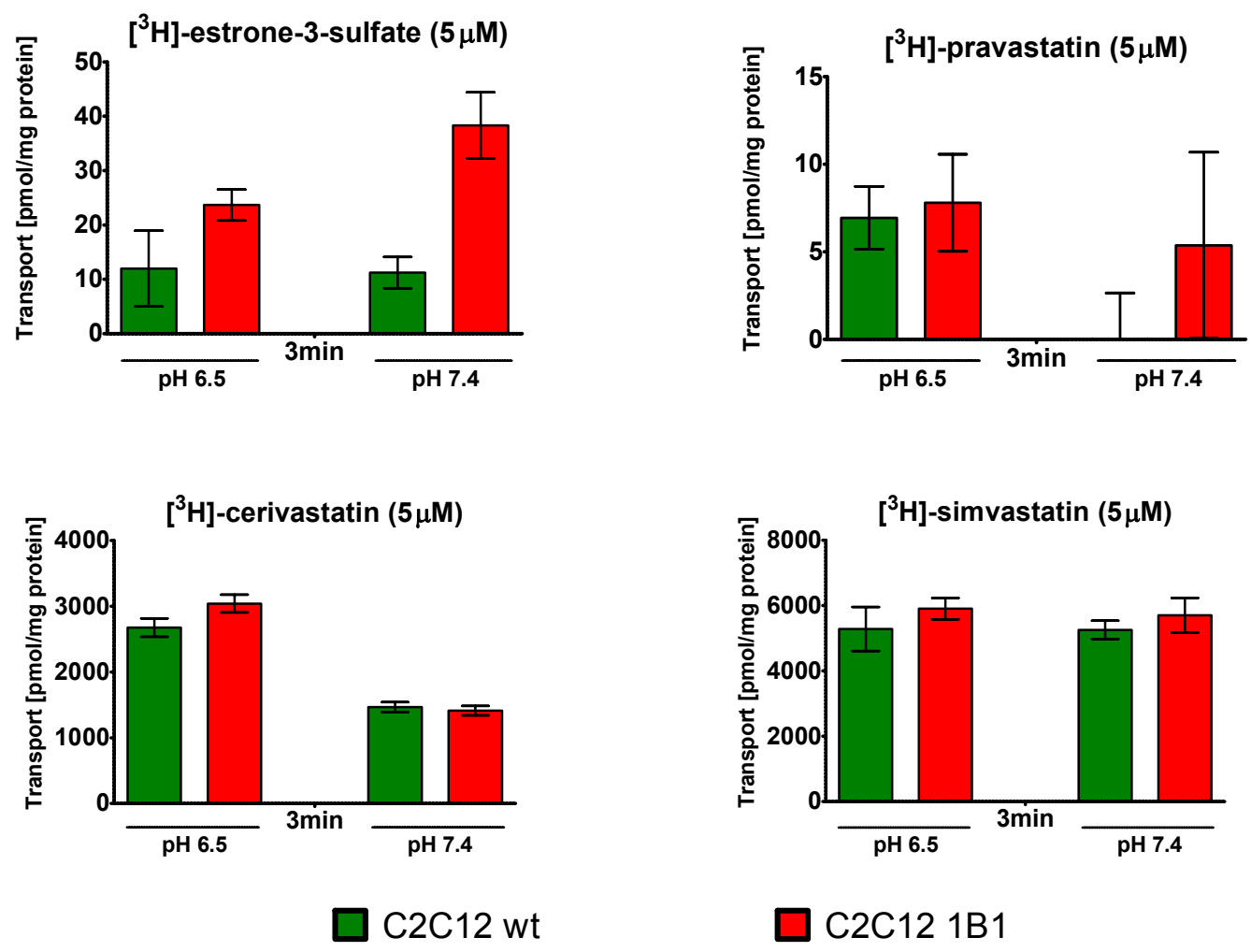

Fig. 15: Comparison of statin transport at $\mathrm{pH} 6.5$ and $\mathrm{pH} 7.4$.

C2C12 1B1 and control cells were incubated for 3 min with $5 \mu \mathrm{M}$ of E3S, pravastatin, simvastatin or cerivastatin. Data show net uptake values calculated by subtraction of zero value. Each data point represents the mean \pm S.D. of three replicates. 


\subsection{Statin toxicity}

To investigate the toxicity of statins against mouse skeletal muscle cells and to study the effect of the statin transporter OATP1B1 on toxicity, C2C12 wt cells and C2C12 1B1 cells were treated with different statins over a broad range of concentrations for $48 \mathrm{~h}$. The cell viability was then assessed with the alamarBlue ${ }^{\circledR}$ assay. The results of this test indicate that the toxicity of statins is different depending on their lipophilicity. While lipophilic statins like cerivastatin or simvastatin are more potent to induce cell death, the hydrophilic pravastatin was not toxic up to $1 \mathrm{mM}$ when cells were treated for $48 \mathrm{~h}$ (Fig. 16). $\mathrm{IC}_{50}$ values between the different cell lines did not differ significantly for all the statins tested (data not shown).

\subsubsection{Impact of OATP inhibition on statin toxicity}

In high concentrations ES3 acts as competitive inhibitor towards another OATP substrate, when both are applied in parallel. As the previous toxicity test showed no difference in toxicity when comparing wild type and transfected cells after statin treatment, the toxicity experiments were repeated in the presence of the OATP1B1 substrate E3S. This allows testing, whether inhibition of OATPs changes the susceptibility of transfected cells towards statins. For this experiment, cells were pretreated with $300 \mu \mathrm{M}$ of E3S one hour before statins were added [52]. E3S alone had no effect on the morphology and viability of C2C12 wt and transfected cells (data not shown). After $72 \mathrm{~h}$, cell viability was assessed using the alamarBlue ${ }^{\circledR}$ assay. In this assay only cerivastatin and simvastatin were tested, as previous studies showed that these two are the most toxic statins, judged by their $\mathrm{IC}_{50}$ values. Results in Fig. 17 show cell viability in percentage of control (DMSO). $\mathrm{IC}_{50}$ values and 95\% confidence intervals are shown in Tab. 9 and were calculated using a four parameter logistic nonlinear regression model.

As shown in Fig. 17, E3S pretreatment exhibited approximately twofold higher $\mathrm{IC}_{50}$ values in $\mathrm{C} 2 \mathrm{C} 12 \mathrm{wt}$ and $\mathrm{C} 2 \mathrm{C} 12$ 1B1 cells treated with cerivastatin $(0.56 \mu \mathrm{M}$ and $0.68 \mu \mathrm{M})$ compared to E3S untreated cells $(0.27 \mu \mathrm{M}$ and $0.27 \mu \mathrm{M})$ (Tab.9), supporting the concept of a transportdependent statin uptake. Interestingly, E3S also had an effect on the wt cells, which is discussed later. The trend for 

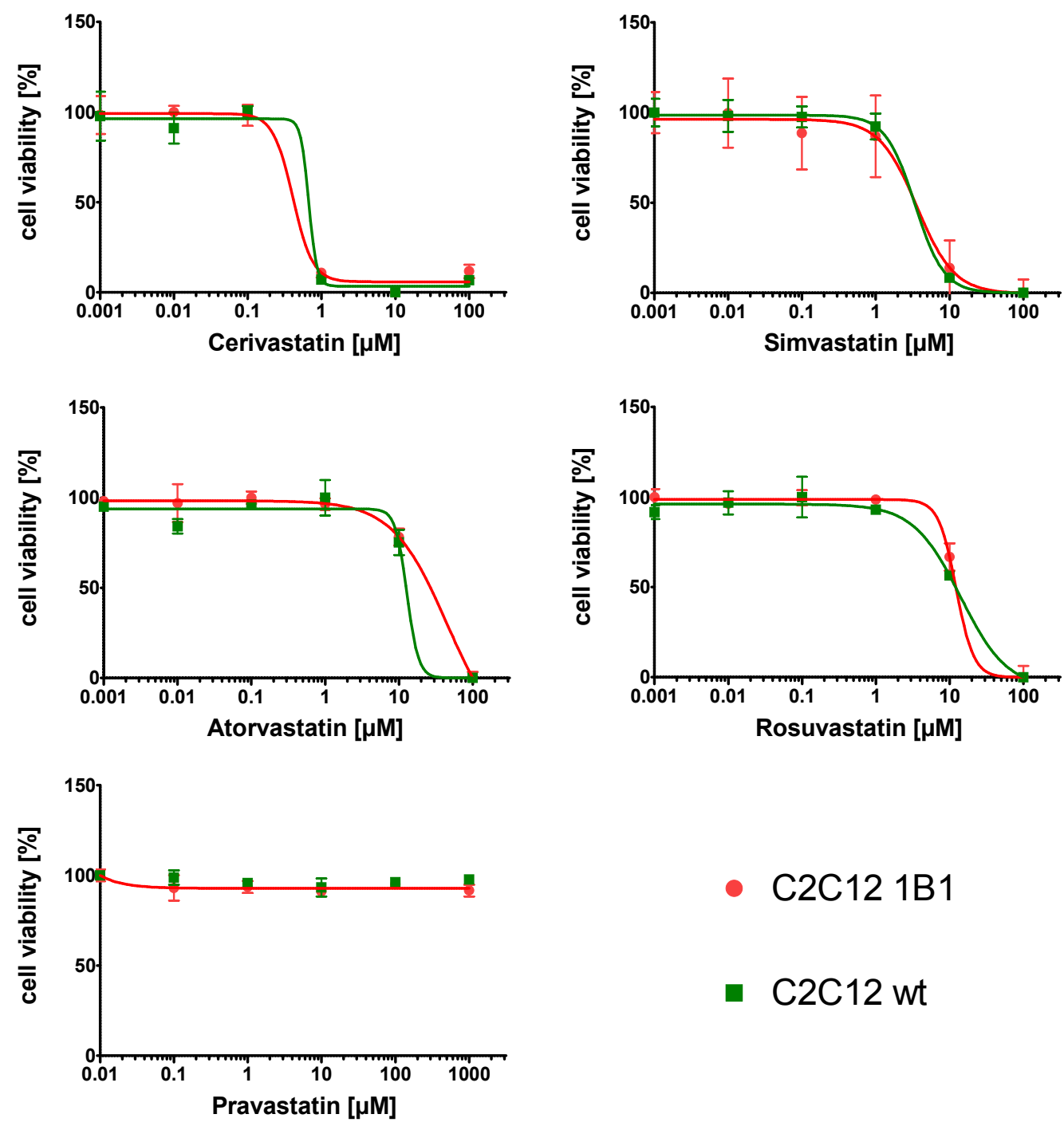

- $\mathrm{C} 2 \mathrm{C} 12$ 1B1

- $\mathrm{C} 2 \mathrm{C} 12 \mathrm{wt}$

Fig. 16: Analysis of cell viability assays after statin treatment.

C2C12 wild type (wt) and OATP1B1 (1B1) cells were treated for $48 \mathrm{~h}$ with different statins. Cell viability was measured with alamarBlue ${ }^{\circledR}$ assay. Cells were exposed to increasing concentrations of statins for $48 \mathrm{~h}$. Each data point represents the mean \pm S.D. of three replicates.

higher $\mathrm{IC}_{50}$ values with E3S pretreatment was also observed for simvastatin but the effect was not as prominent as with cerivastatin. Here, $\mathrm{IC}_{50}$ values are also higher when cells are pretreated with E3S, but 95\% confidence intervals are overlapping (Tab. 9). 

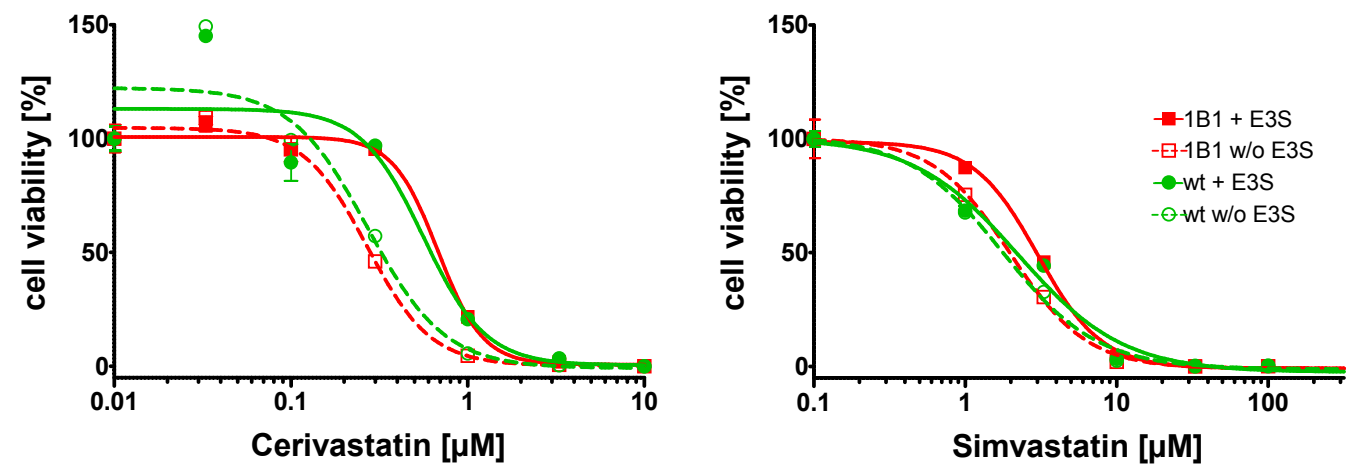

Fig. 17: Cell viability after statin treatment with or without pretreatment of competitive inhibitor E3S.

Cells were treated with cerivastatin (left) or simvastatin (right).

Pretreatment was conducted $1 \mathrm{~h}$ before statins were added with $300 \mu \mathrm{M}$ E3S (+E3S) or DMSO (w/o E3S). Each data point represents the mean \pm S.D. of three replicates.

\begin{tabular}{|c|c|c|c|c|c|c|c|c|}
\hline \multirow{1}{*}{} & \multicolumn{3}{|c|}{ C2C12 1B1 } & \multicolumn{3}{c|}{ C2C12 WT } \\
\cline { 2 - 9 } & \multicolumn{2}{|c|}{$+\mathrm{E} 3 \mathrm{~S}$} & \multicolumn{2}{c|}{$\mathrm{W} / \mathrm{O}$ E3S } & \multicolumn{2}{c|}{$+\mathrm{E} 3 \mathrm{~S}$} & \multicolumn{2}{c|}{ W/O E3S } \\
\cline { 2 - 9 } & $\mathrm{IC}_{50}[\mu \mathrm{M}]$ & $\begin{array}{c}95 \% \text { Conf. } \\
\text { Interval }\end{array}$ & $\mathrm{IC}_{50}[\mu \mathrm{M}]$ & $\begin{array}{c}95 \% \text { Conf. } \\
\text { Interval }\end{array}$ & $\mathrm{IC}_{50}[\mu \mathrm{M}]$ & $\begin{array}{c}95 \% \text { Conf. } \\
\text { Interval }\end{array}$ & IC $_{50}[\mu \mathrm{M}]$ & $\begin{array}{c}95 \% \text { Conf. } \\
\text { Interval }\end{array}$ \\
\hline Cerivastatin & 0.68 & $\begin{array}{c}0.59 \text { to } \\
0.77\end{array}$ & 0.27 & $\begin{array}{c}0.24 \text { to } \\
0.31\end{array}$ & 0.56 & $\begin{array}{c}0.35 \text { to } \\
0.90\end{array}$ & 0.27 & $\begin{array}{c}0.19 \text { to } \\
0.39\end{array}$ \\
\hline Simvastatin & 3.02 & $\begin{array}{c}2.80 \text { to } \\
3.25\end{array}$ & 1.98 & $\begin{array}{c}1.65 \text { to } \\
2.37\end{array}$ & 2.24 & $\begin{array}{c}1.79 \text { to } \\
2.82\end{array}$ & 1.77 & $\begin{array}{c}1.50 \text { to } \\
2.09\end{array}$ \\
\hline
\end{tabular}

Tab. 9: $\mathrm{IC}_{50}$ values and 95\% confidence intervals of cell viability assay. Cells were treated with $(+\mathrm{E} 3 \mathrm{~S})$ or without $(\mathrm{w} / \mathrm{o}$ E3S) E3S $(300 \mu \mathrm{M})$ prior statin treatment.

\subsection{Investigations to study the expression of OATP1B1 in transfected $\mathrm{C} 2 \mathrm{C} 12$ cells}

After having identified a functional active clone of C2C12 cells transfected with OATP1B1, investigatoins were performed to study the expression and the localization of OATP1B1 at the protein and RNA level. 


\subsubsection{Subcellular localization of OATP1B1 in C2C12 cells}

To test subcellular localization of the OATP1B1 protein in the cell membrane of $\mathrm{C} 2 \mathrm{C} 12$ cells, immunocytochemistry experiments were conducted. $\mathrm{CHO}$ cells transfected with OATP1B1 were used as control, as these cells are well known to express OATP1B1 [61]. After cells were confluent they were treated with a fixation solution containing Triton $X-100$. Best results were obtained with 0.75\% Triton X-100 (data not shown). The primary antibody used, was a rabbit anti-OATP1B1-antibody [57]. The results of immunocytochemistry are shown in Fig. 18 and demonstrate that OATP1B1 is expressed in the cell membrane of CHO OATP1B1 cells. To get a proper signal from the transfected cell line, the laser power was increased by about a factor of three. C2C12 wt cells were then recorded with the same settings. The transfected cell line did not show the expected expression of OATP1B1 in the cell membrane, instead the signal appeared all over the cell. However, it seemed that the signal in the transfected cells was slightly stronger compared to control cells indicating that transfection was successful, but the protein is not integrated in the plasma membrane.

\subsubsection{Western blot analysis of C2C12 1B1 cells}

As immunocytochemistry failed to demonstrate the proper expression of OATP1B1, Western blot analysis was used to test for OATP1B1expression. Therefore, cells were lysed with RIPA-buffer; proteins were separated by gel electrophoresis and transferred to nitrocellulose membrane. The primary antibody was a rabbit anti-OATP1B1-antibody produced previously in this laboratory [57]. Although the method was optimized and several parameters like antibody concentration, incubation time and temperature where modified, results were not reproducibly conclusive. The inhouse antibody was raised against the C-terminus [57]. In addition, different commercially available antibodies were tested, which were raised against the middle region (A) and against the N-terminus (B). The antibodies tested were:

A - SLCO1B1 antibody (middle region) from Aviva Systems Biology (ARP43914_P050),

B - Mouse monoclonal antibody against SLCO1B1 from Creative Diagnostics (CABT-36050MH). 


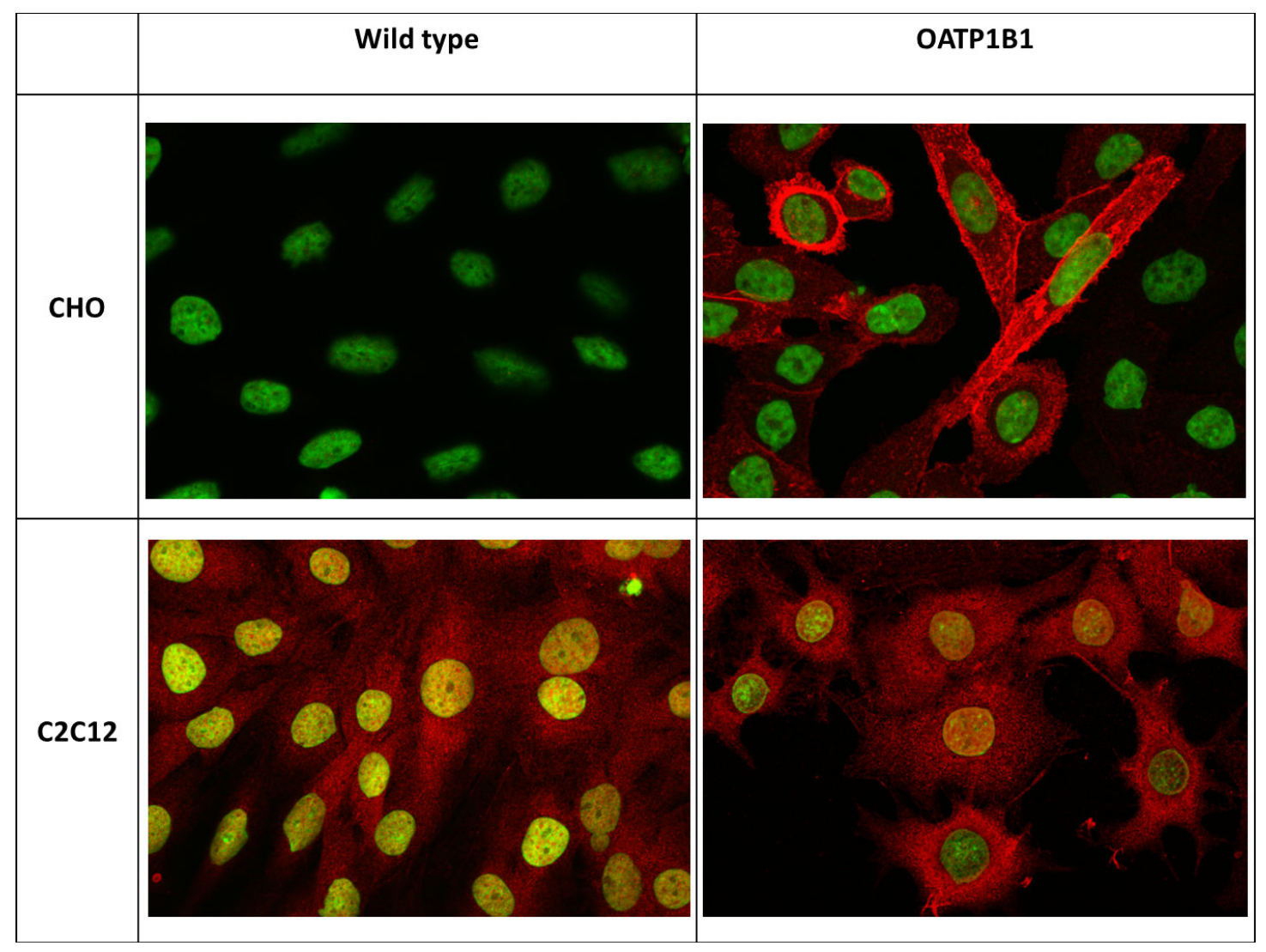

Fig. 18: Analysis of confocal laser scanning microscopy.

Cells were stained with anti-OATP1B1-antibody, followed by Alexa Fluor ${ }^{\circledR} 488$ anti-rabbit IgG secondary antibody (red) plus DAPI staining for nuclei (green). Laser power was increased by about a factor of three for $\mathrm{C} 2 \mathrm{C} 12$ cells.

All Western blots performed with the commercial antibodies failed to show OATP1B1 in CHO cells expressing OATP1B1 (data not shown). Therefore, these antibodies were not used for further investigations.

\subsection{3 qRT-PCR using TaqMan ${ }^{\circledR}$ based gene expression analysis to detect OATP1B1 RNA}

To analyze the expression of OATP1B1 at the RNA level, a quantitative real time PCR was performed with RNA extracts from C2C12 1B1, CHO OATP1B1 and the corresponding control cells. Data were normalized to mouse beta-actin RNA. Expression level of wild type cells were used as calibrator and set to one, although they do not express OATP1B1. CHO OATP1B1 cells show about one thousand fold change of OATP1B1 mRNA compared to the wt cells, while C2C12 1B1 cells do not show any difference in OATP1B1 expression compared 
to the wild type cells (Fig. 19). It was not possible to detect the RNA of OATP1B1 in the clone, which was selected previously by its transport results shown in Fig. 11. The experiment was repeated several times but OATP1B1 expression was not observed in the clone.

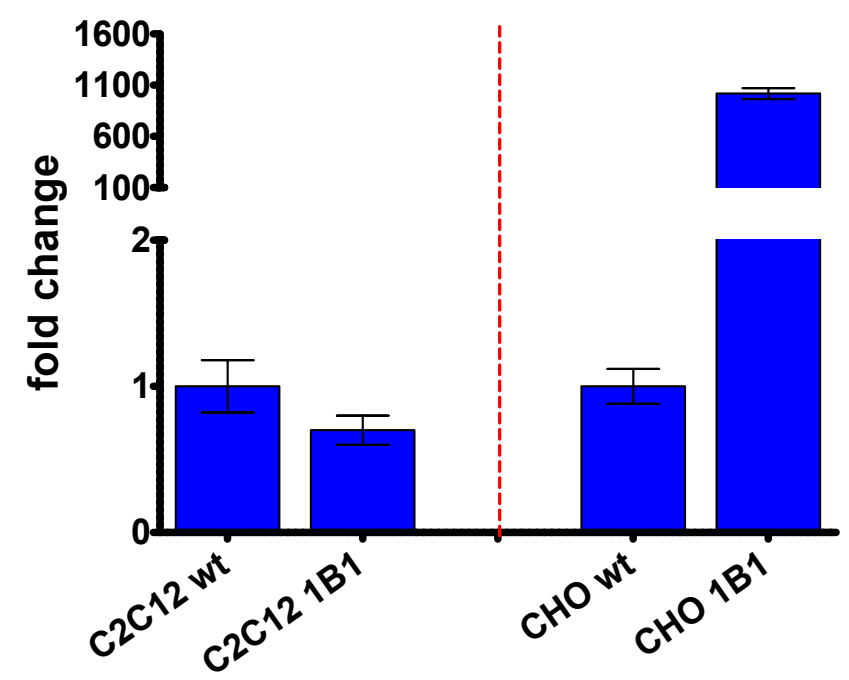

Fig. 19: Relative mRNA expression of OATP1B1

Bars indicate fold change of OATP1B1 mRNA expression normalized to the corresponding wild type cell line. Each data point represents the mean \pm S.D. of three replicates.

\subsection{Rat L6 cells transfected with OATP1B1 or -1B3}

As the results with $\mathrm{C} 2 \mathrm{C} 12$ cells were inconclusive, investigations were then focused on the L6 cell line which was already transfected. The limiting dilution cloning to obtain single clones was already conducted in parallel to the C2C12 investigations. Here, about 50 clones per gene were obtained. In the first step, RNA of 25 clones of each gene of interest was isolated and a qRT-PCR was performed to check the RNA expression level of OATP1B1 or -1B3. To simplify the analysis, the results shown in Fig. 20 are presented as fold change of wild type cells. Data were normalized to rat beta-actin. The qRT-PCR reveals that RNA of OATP1B1 or- 1B3 is expressed in several clones of L6 cells. Clones showing a high expression level of the respective gene were selected to for further analysis. The expression of the OATP1B1 rat orthologue Slco1b2 was additionally tested in this assay. Both sequences exhibit a 75\% identity at mRNA-level when they were aligned using BLAST. The OATP2B1 rat orthologue Slco2b1 was also 
tested as this transporter has been shown previously to transport statins as well [92]. For both genes it was not possible to detect RNA in C2C12 wt cells.
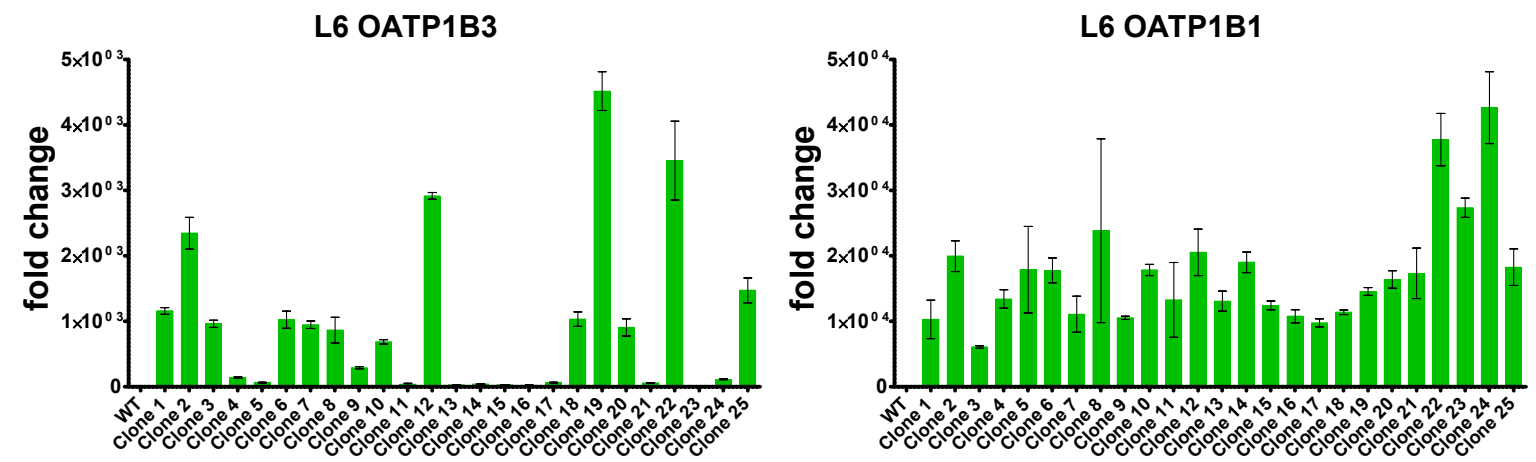

Fig. 20: Relative mRNA expression of OATP1B1 or -1B3 in L6 clones The qRT-PCRs were performed with cDNA samples from isolated mRNA of L6 clones transfected with OATP1B1 or -1B3 cDNA. Bars indicate the fold change mRNA expression of OATP1B3 (left) and OATP1B1 (right). Each data point represents the mean \pm S.D. of three replicates.

For further characterization the following clones were selected:

- L6 OATP1B1: Clone2, 8, 12, 14, 22, 23, 24,

- L6 OATP1B3: Clone2, 3, 6, 12, 19, 22. 
Western blots were performed to elucidate the expression of OAPT1B1 or -1B3 at the protein level. Therefore, cells were lysed at a confluency of about $90 \%$ using RIPA-buffer containing protease inhibitors. Nitrocellulose membranes were probed with rabbit anti-OATP1B1-antibody [57] or rabbit anti-OATP1B3antibody [81]. Fig. 21 shows the Western blot analyses of cell lysates of L6 clones expressing OATP1B1 and control cells. As OATP1B1 has previously been shown to appear around $75 \mathrm{kDa}$ [81], the band of interest is located between $75 \mathrm{kDa}$ and $100 \mathrm{kDa}$ as indicated by an arrow in Fig. 21 . The positive control CHO OATP1B1 (Fig. 21, lane 10) shows high expression of OATP1B1. In all tested clones OATP1B1 is not expressed, as the band of interest also appears in the wild type control.

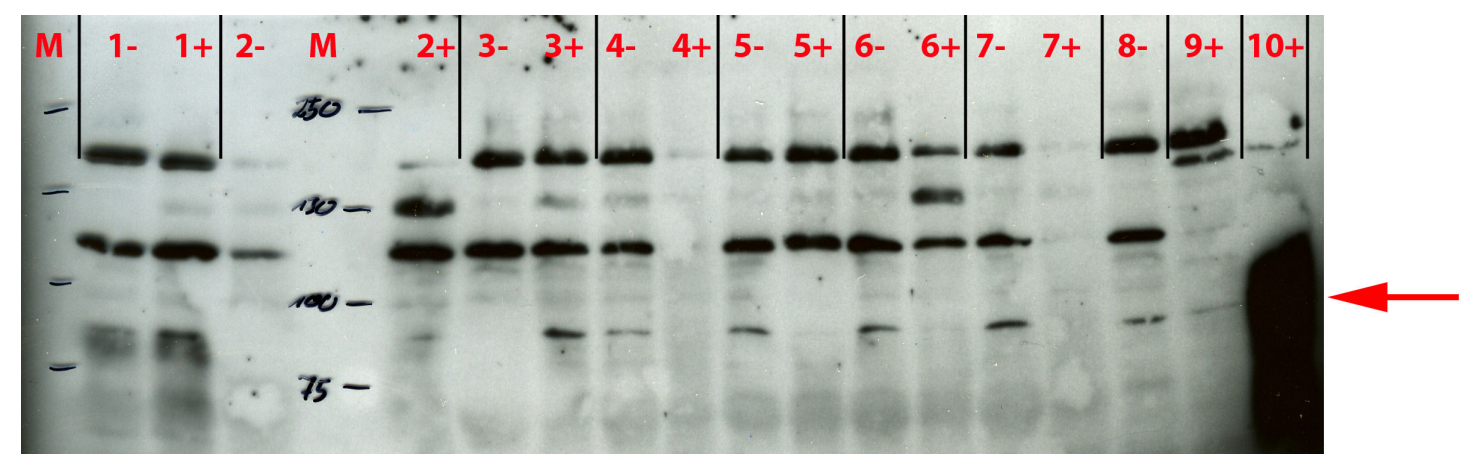

Fig. 21: Western blot analysis of OATP1B1 expressed in different clones of L6 cells

Cells were treated with (+) or without (-) sodium butyrate. M: Marker,

1: Clone 2, 2: Clone 8, 3: Clone 12, 4: Clone 14, 5: Clone 22; 6: Clone 23,

7: Clone 24, 8: L6 wt, 9: CHO wt, 10: CHOOATP1B1

Western blot analyses of L6 clones expressing OATP1B3 and control cells are shown in Fig. 22. OATP1B3 has 702 amino acids and was previously shown to appear with a double band at $75 \mathrm{kDa}$ and $105 \mathrm{kDa}$ on Western blots [81]. The positive control clearly shows expression of OATP1B3 (Fig. 22, lane 2). Comparing clones of L6 transfected with OATP1B3 (Fig. 22, lane 3-8) with wt cells (Fig. 22,lane 9) reveals no difference in OATP1B3 expression suggesting that OATP1B3 is not or only to minor extent expressed in the clones tested.

In parallel to these experiments, trials were run to show OATP1B1 or -1B3 protein with confocal laser scanning microscopy in the selected L6 clones. Therefore, cells were seeded on sterile cover slips and grown until confluency. Cells were fixed with fixing solution, where best results were obtained with $0.75 \%$ Triton X-100. Fixed cells were probed with affinity purified rabbit anti-OATP1B1antibody followed by goat anti-rabbit IgG Alexa Fluor ${ }^{\circledR} 488$-conjugat antibody. 


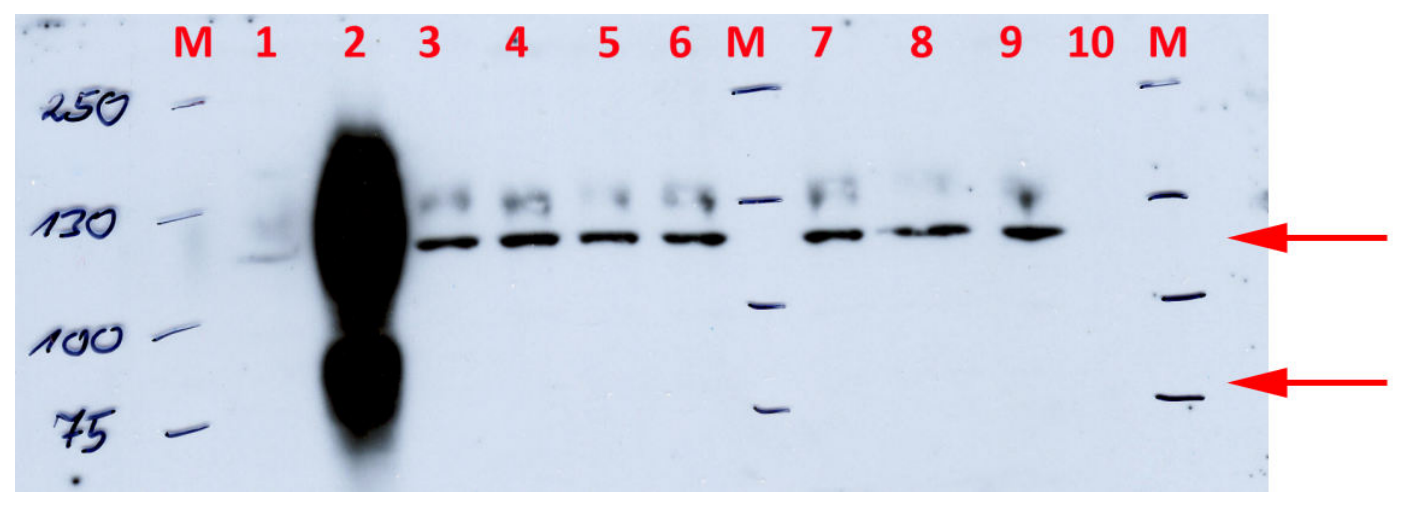

Fig. 22: Western blot analysis of OATP1B3 expressed in different clones of L6 cells

M: Marker, 1: CHO wt, 2: CHOOATP1B3, 3: L6 clone 2, 4: L6 clone 3, 5: L6 clone 6, 6: L6 clone 12, 7: L6 clone 19, 8: L6 clone 22, 9: L6 wt, 10: empty

Several attempts failed to show OATP1B1 expression in L6 clones although $\mathrm{CHO}$ control cells showed strong expression of transport protein in the cell membrane (Fig. 23). Same holds true for the selected L6 clones transfected with OATP1B3 cDNA. 


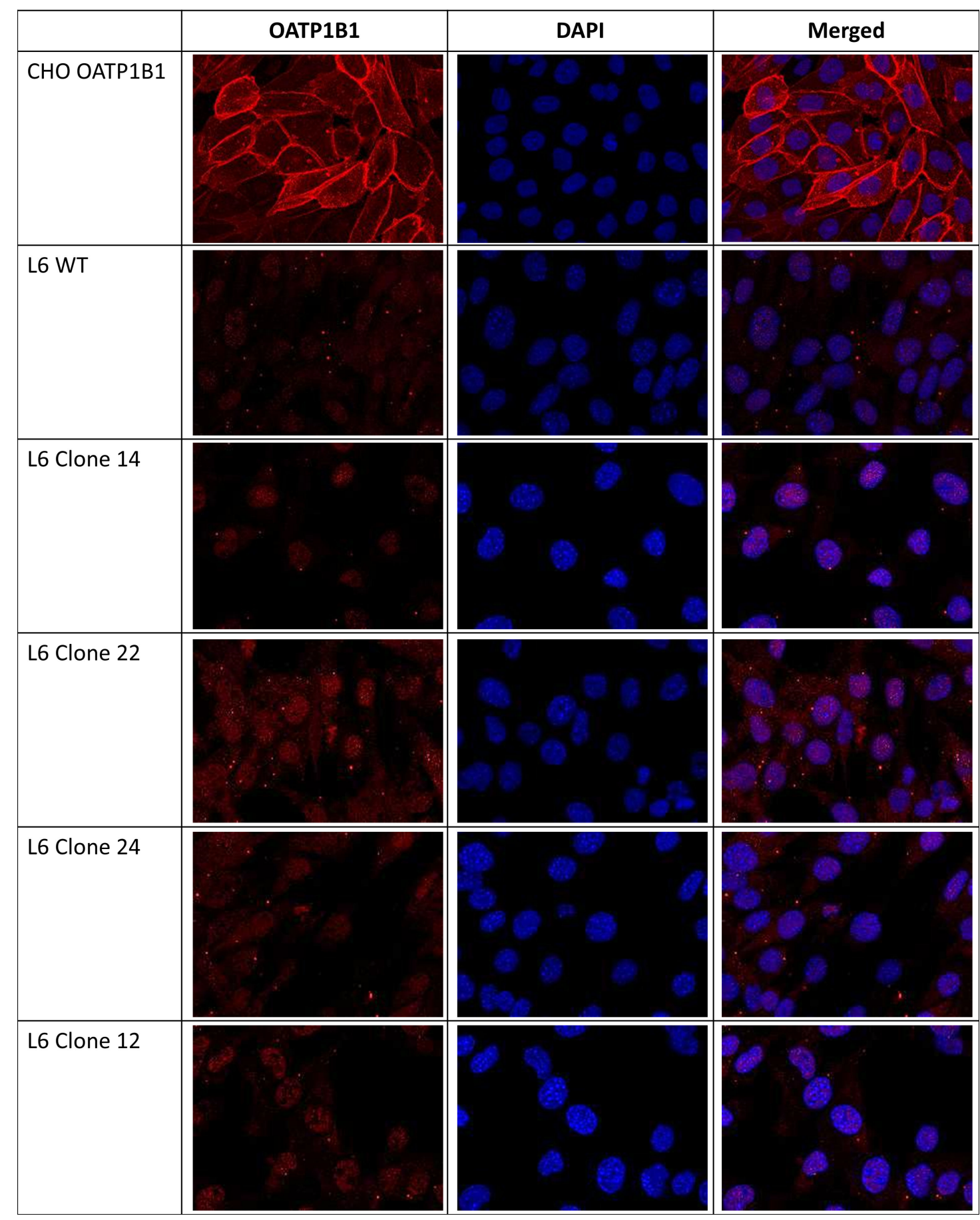

Fig. 23: Analysis of confocal laser scanning microscopy

L6 clones transfected with OAPT1B1 cDNA and control cells. Samples were probed with affinity purified rabbit anti-OATP1B1-antibody followed by goat anti-rabbit IgG Alexa Fluor ${ }^{\circledR} 488$-conjugat antibody (red) and DAPI (blue) to stain nuclei. Laser power was increased about factor two for L6 cells. 


\subsection{New transfection of $\mathrm{C} 2 \mathrm{C} 12$ and $\mathrm{L} 6$ cells}

As it was not possible to demonstrate expression of either the OATP1B1 and -1B3 RNA, it was reasoned the vector so far used may not be compatible with C2C12 or L6 cells. Therefore, pcDNA3.1+ was used next. The new vector pcDNA3.1+ was previously shown to work with C2C12 and L6 cells to stably express the $\alpha 1$ - and $\alpha 2$-subunit of AMP-activated protein kinase [93]. Additionally, pcDNA3.1+ contains the BGHpA site, which is a signal for accurate and efficient polyadenylation [94], while pIRESneo2 contains only a synthetic intron (IVS) known to enhance the stability of the mRNA [95]. It has been clearly established that the poly(A) tail is essential for the stability, transport across the nuclear membrane, and translation of most mRNAs [96, 97].

\subsubsection{Recloning of OATP1B1 and OATP1B3 cDNA from pIRES- neo2 into pcDNA3.1+}

After cloning of OATP1B1/ -1B3 cDNA into pcDNA3.1+ and transformation of plasmids into competent E.coli, several clones were picked and DNA was isolated. DNA of four clones of each cDNA was sent for sequencing using only the flanking primers of the inserted gene (T7 and BGH-reverse) to check the correct orientation. As all clones were positive, the integrity of these expression vectors and the lack of mutations were confirmed by DNA sequencing of the insert. Prior to transfection, plasmids were linearized using restriction enzyme XhoI and subsequently separated with an agarose gel to check proper linearization. Undigested plasmids appear at lower molecular weight as the circular form tends to supercoil, and thus migrates faster through the gel (Fig. 24, lanes 1 and 4), while the linear form appears at higher molecular weight (Fig. 24, lanes 2 and 5).

\subsubsection{Transfection of muscle cells using pcDNA3.1+ vector}

For transfecting L6 and $\mathrm{C} 2 \mathrm{C} 12$ with the new plasmids the same conditions were used as already described (Tab.7). All different transfection conditions resulted in surviving cell. Therefore, RNA was isolated from all these cells to check 


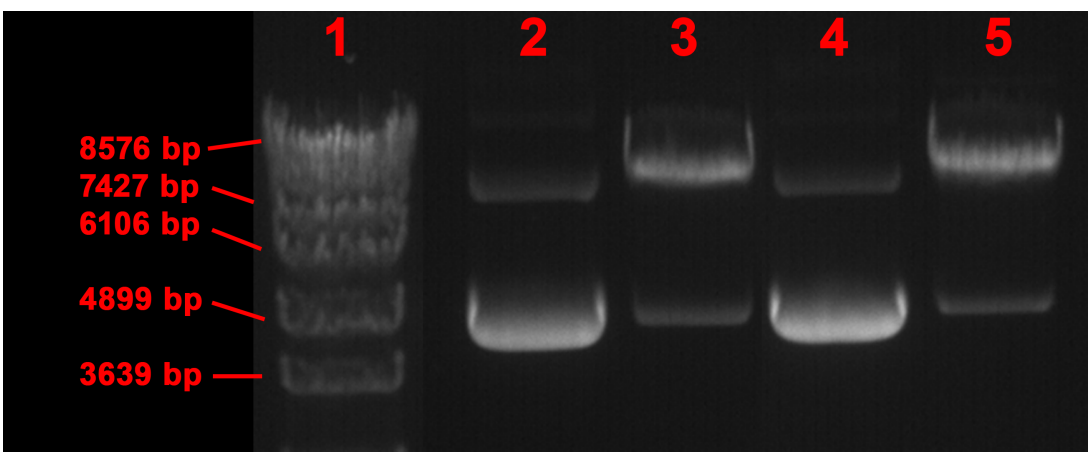

Fig. 24: Linearization of plasmids after cloning OATP1B1 and OATP1B3 into pcDNA3.1+

1: OATP1B3 undigested, 2: OATP1B3 linearized, 3: Marker, 4:

OATP1B1 undigested, 5: OATP1B1 linearized

the mRNA levels of OATP1B1 and -1B3 by qRT-PCR. All samples showed high amount of the expected RNA (Fig. 25).

Subsequently a limiting dilution cloning of all transfection conditions was performed to receive single cell clones. The clones obtained in this assay are listed in Tab. 10. The strategy was changed this time to avoid problems encountered in the previous rounds of characterization, where a functional active clone was identified without reproducibly demonstrating the expression of OATP1B1 or$1 \mathrm{~B} 3$ at the protein or RNA level. During the limiting dilution cloning, before freezing the single cell clones for the first time, all clones were tested for uptake of sodium fluorescein (NaFluo) and in parallel cell lysates were prepared for possible later RNA isolation. As NaFluo is a substrate of the OATPs [98], this assay allowed to quickly decide whether a clone is suitable or not. Therefore, clones were seeded in 6-well plates (single point measurement) and cultured until $80-90 \%$ confluency. To measure uptake, cells were incubated with $5 \mu \mathrm{M}$ NaFluo for $5 \mathrm{~min}$. Plates were then immediately observed under fluorescent microscope. Clones showing no uptake at all were excluded from further investigations. The clones selected for further characterization are listed in Tab.11.

\begin{tabular}{|l|c|c|c|}
\hline \multicolumn{2}{|c|}{ C2C12 } & \multicolumn{2}{c|}{ L6 } \\
\hline condition & \# clones & condition & \# clones \\
\hline C2C12 1B3 5:2 & $\mathbf{2 1}$ & L6 1B3 5:2 & $\mathbf{8}$ \\
\hline C2C12 1B3 7:2 & 14 & L6 1B3 7:2 & $\mathbf{6}$ \\
\hline C2C12 1B3 9:2 & $\mathbf{1 0}$ & L6 1B3 9:2 & $\mathbf{5}$ \\
\hline C2C12 1B1 5:2 & $\mathbf{1 9}$ & L6 1B1 5:2 & $\mathbf{6}$ \\
\hline C2C12 1B1 7:2 & $\mathbf{1 8}$ & L6 1B1 7:2 & $\mathbf{4}$ \\
\hline C2C12 1B1 9:2 & $\mathbf{2 2}$ & L6 1B1 9:2 & $\mathbf{3}$ \\
\hline
\end{tabular}

Tab. 10: Amount of clones received by limiting dilution cloning. 

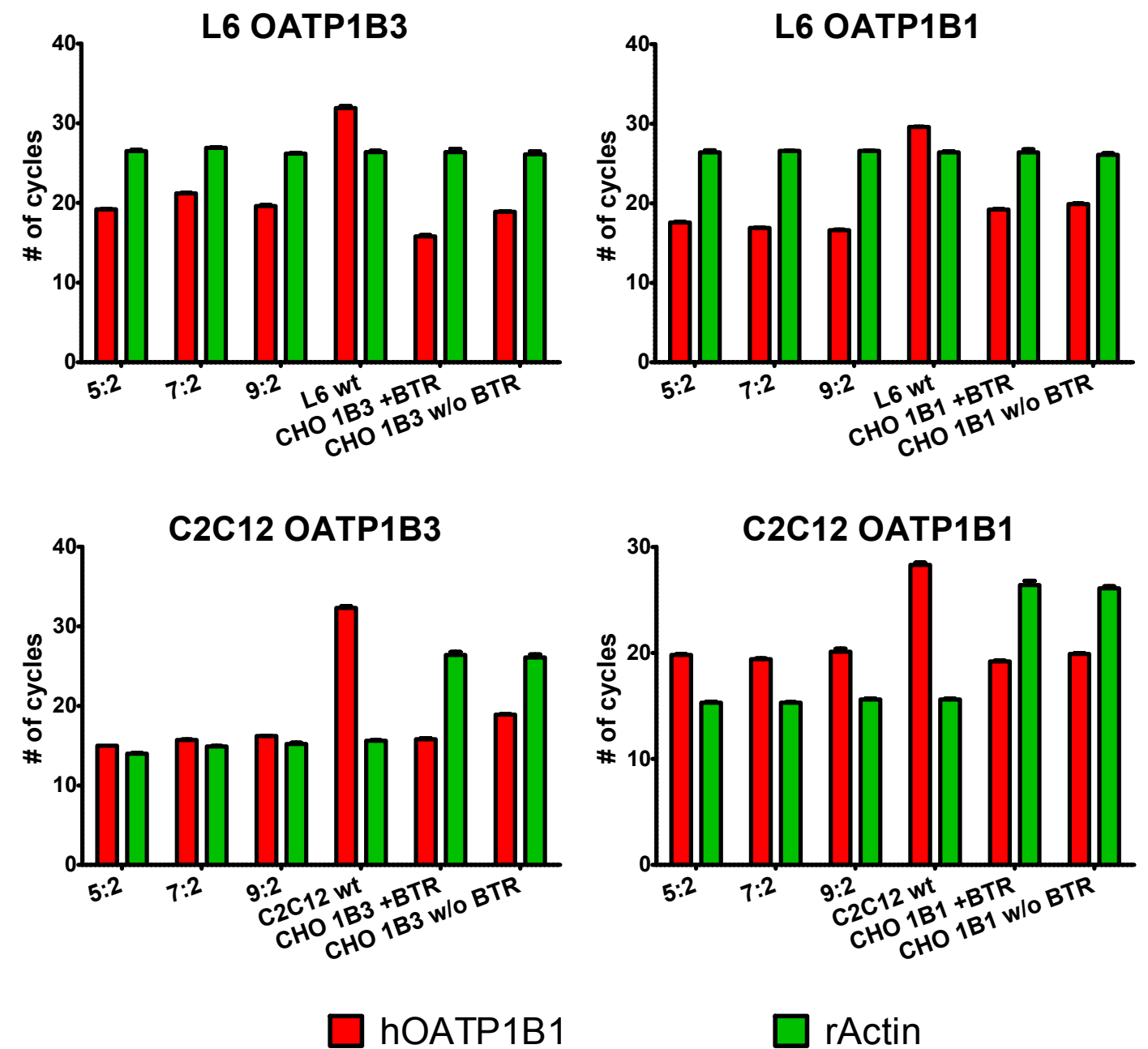

Fig. 25: qRT-PCR results of transfection conditions

The qRT-PCRs were run with cDNA samples from isolated mRNA of transfection conditions. Bars indicate the ct-values of fluorescent signal to cross the threshold. Gene of interest is indicated in red and housekeeping gene in green. Each data point represents the mean \pm S.D. of three replicates.

\begin{tabular}{|r|r|r||r|r|r|}
\hline \multicolumn{3}{|c||}{ C2C12 OATP1B1 } & \multicolumn{3}{c|}{ C2C12 OATP1B3 } \\
\hline $5: 2$ & $7: 2$ & $9: 2$ & $5: 2$ & $7: 2$ & $9: 2$ \\
\hline 5 & 2 & 1 & 6 & 2 & 6 \\
\hline 10 & 5 & 7 & 9 & 5 & 10 \\
\hline 12 & 12 & 11 & 12 & 12 & \\
\hline 14 & 14 & & 15 & & \\
\hline 16 & & & 16 & & \\
\hline & & & 17 & & \\
\hline
\end{tabular}

Tab. 11: Clones selected after NaFluo uptake assay for further investigations.

\subsection{3 qRT-PCR using TaqMan ${ }^{\circledR}$ based gene expression analysis to detect OATP1B1 and -1B3 RNA}

Subsequently the RNA of the preselected clones was isolated from the samples prepared during the limiting dilution cloning to check the expression level of 
OATP1B1 or -1B3 by qRT-PCR after reverse transcription. Results of qRT-PCR revealed that several clones express OATP1B1 or -1B3 mRNA in C2C12 cells, respectively (Fig. 26).
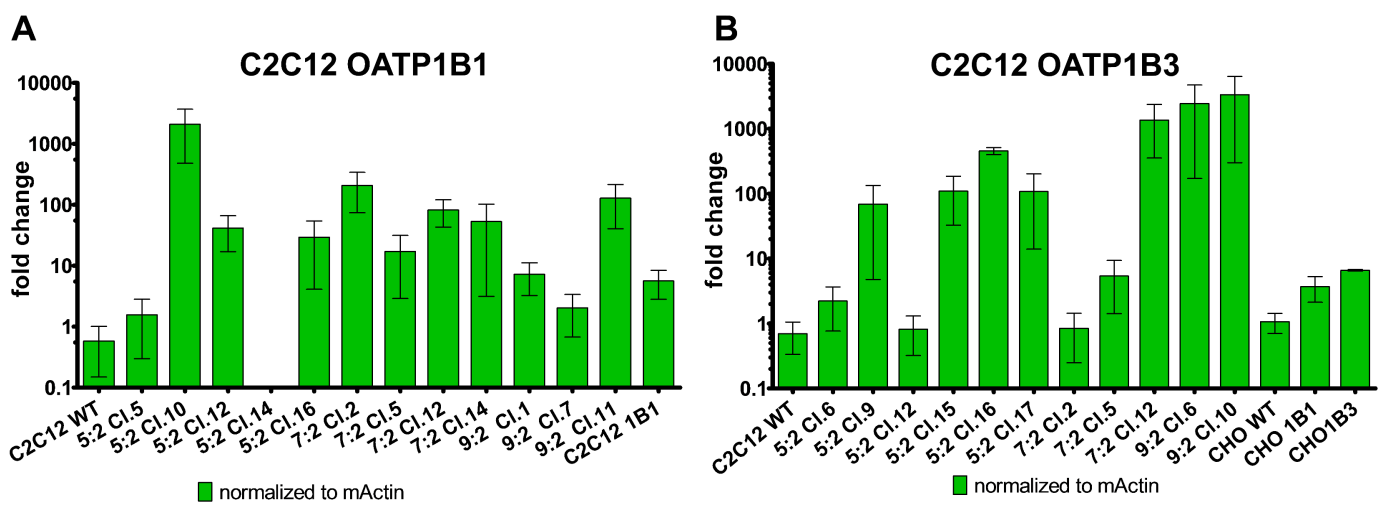

Fig. 26: qRT-PCR results of C2C12 clones expressing OATP1B1 or -1B3 The qRT-PCRs were run with cDNA samples from isolated mRNA of $\mathrm{C} 2 \mathrm{C} 12$ clones transfected with OATP1B1 or -1B3 cDNA. Bars indicate the log fold change of mRNA expression of OATP1B1 (A) and OATP1B3 (B). Each data point represents the mean \pm S.D. of three replicates.

\subsubsection{Functional screening using the transport assay}

Based on these results, clones showing the highest expression level were chosen (Tab. 12) to be tested for uptake using $\left[{ }^{3} \mathrm{H}\right]-\mathrm{E} 3 \mathrm{~S}$ to evaluate uptake rates quantitatively.

\begin{tabular}{|c|c|}
\hline C2C12 OATP1B1 & C2C12 OATP1B3 \\
\hline 1B1 5:2 10 & 1B3 5:2 9 \\
\hline 1B1 5:2 16 & 1B3 5:2 16 \\
\hline 1B1 7:2 2 & 1B3 7:2 12 \\
\hline 1B1 7:2 5 & 1B3 9:2 6 \\
\hline 1B1 7:2 12 & 1B3 9:2 10 \\
\hline 1B1 7:2 14 & \\
\hline 1B1 9:2 11 & \\
\hline
\end{tabular}

Tab. 12: Clones selected after qRT-PCR for further investigation.

The uptake assay revealed that three clones of C2C12 OATP1B1 (7:2 Clone2, 7:2 Clone5, and 7:2 Clone14) showed proper transport (Fig. 27). For OATP1B3 none of the selected clones showed suitable transport values. The previously 
selected clone C2C12 1B1 was run as positive control and showed about five times more uptake than $\mathrm{C} 2 \mathrm{C} 12$ wt cells. For both uptake assays the control cell lines $\mathrm{CHO}$ 1B1 and CHO 1B3 showed low uptake values. These values are typical for uptakes assays where $\mathrm{NaB}$ treatment $24 \mathrm{~h}$ prior conducting the assay is omitted. $\mathrm{NaB}$ was previously shown to boost protein expression in $\mathrm{CHO}$ cells [84]. As the effect of $\mathrm{NaB}$ to $\mathrm{C} 2 \mathrm{C} 12$ cell is unknown, the screening was performed without $\mathrm{NaB}$ treatment. After finally selecting the best clone, namely C2C12 OAPT1B1, 7:2 Clone2 (hereinafter called C2C12 1B1 C1.2) the question arose if $\mathrm{NaB}$ pre-treatment can enhance transport. To test whether $\mathrm{NaB}$ is toxic at all, a cell viability assay was performed over a broad range of concentrations up to $200 \mathrm{mM}$. The results (Fig. $28 \mathrm{~A}$ ) revealed that $\mathrm{NaB}$ is toxic but only in the high millimolar range. Cell viability of $\mathrm{NaB}$ treated cells starts to decrease at $1 \mathrm{mM}$. As $\mathrm{CHO}$ cells are routinely treated with $5 \mathrm{mM}$ in our lab prior to the uptake assay [84], different concentrations of $\mathrm{NaB}$ were applied to investigate its influence on the performance of the selected clone (C2C12 1B1 C1.2). Therefore, cells were treated with $\mathrm{NaB}$ at $0.1 \mathrm{mM}, 1 \mathrm{mM}, 5 \mathrm{mM}$ and $10 \mathrm{mM}$ $24 \mathrm{~h}$ prior to the uptake assay. However, $\mathrm{NaB}$ can indeed enhance E3S uptake into the newly selected clone (Fig. $28 \mathrm{~B}$ ). Highest uptake rates were observed at $5 \mathrm{mM}$ and $10 \mathrm{mM}$. C2C12 wt cells and the previously selected clone C2C12 1B1 served as untreated negative or positive assay controls, respectively. As $\mathrm{NaB}$ is toxic for $\mathrm{C} 2 \mathrm{C} 12$ cells in the mM-range when treated for $48 \mathrm{~h}$, all subsequent investigations with $\mathrm{C} 2 \mathrm{C} 12$ cells were conducted with $5 \mathrm{mM} \mathrm{NaB}$ treatment $24 \mathrm{~h}$ prior to the assay.

To characterize the new selected clone, a time course experiment was performed, where wild type and transfected cells were incubated with E3S $(5 \mu \mathrm{M})$ for 5,10 , 20 , and $30 \mathrm{~min}$. Cells were treated with $\mathrm{NaB}(5 \mathrm{mM}) 24 \mathrm{~h}$ prior to the uptake assay. The earlier selected clone C2C12 1B1 was used as positive control. As shown in Fig. 29 the uptake reaches a plateau after approximately $20 \mathrm{~min}$ for C2C12 1B1 and for the new clone C2C12 1B1 C1.2. The uptake after 20 min was about three fold higher for C2C12 1B1 Cl.2 and four fold higher for C2C12 1B1, showing the functional expression of OATP1B1 in the new selected clone. 

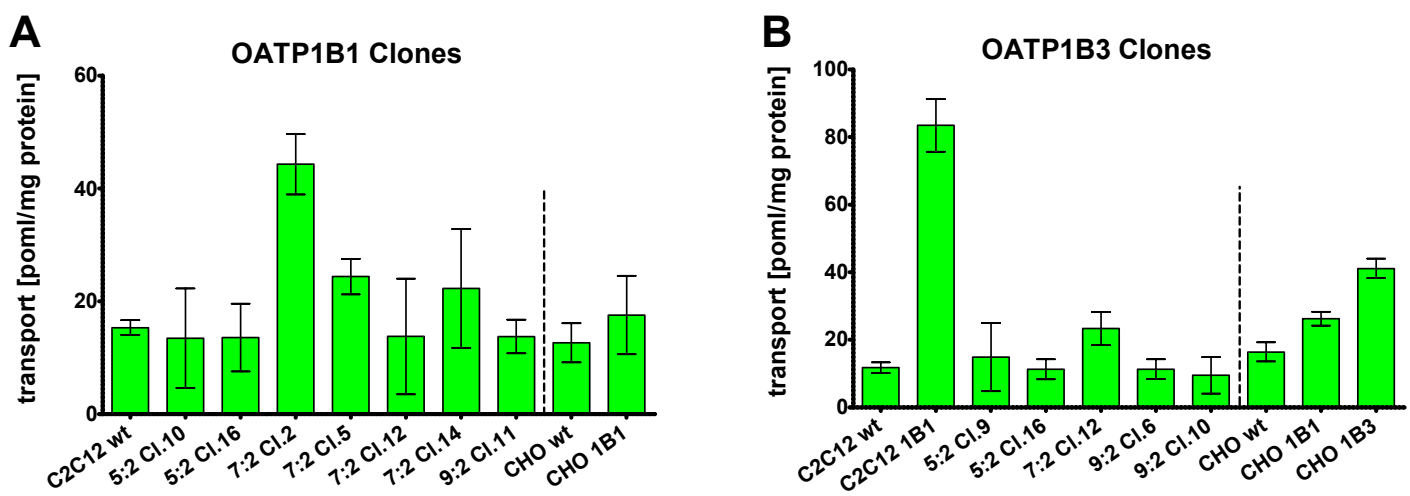

Fig. 27: Uptake of $\left[{ }^{3} \mathrm{H}\right]$-E3S into different clones of $\mathrm{C} 2 \mathrm{C} 12$ cells expressing OATP1B1 (A) or -1B3 (B)

Clones were selected by qRT-PCR where they showed high levels of OATP1B1 or -1B3 mRNA. Green bars represent net-uptake and blues bars represent transport specific uptake (subtraction of wild type uptake). Each bar represents mean \pm S.D. of three replicates.

A

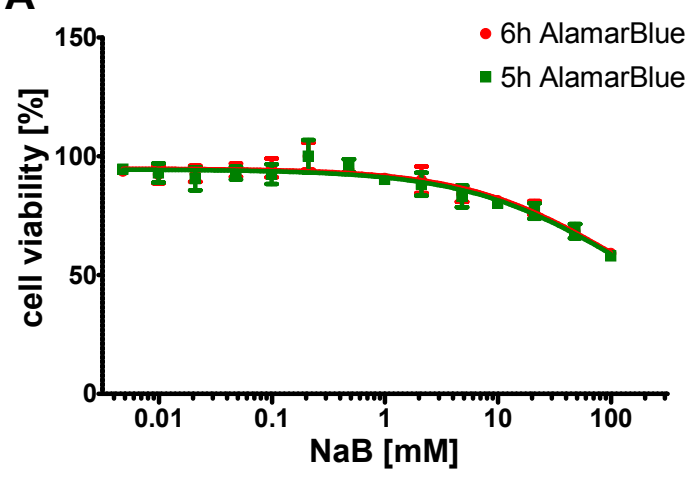

B

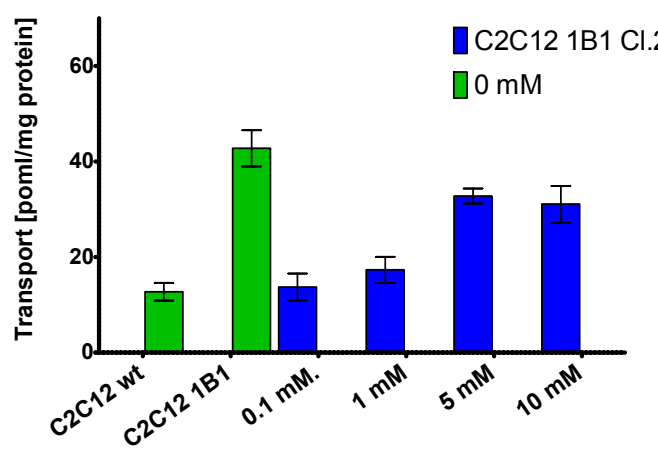

Fig. 28: Influence of sodium butyrate (NaB).

(A) Cell viability of C2C12 wild type cells after sodium butyrate $(\mathrm{NaB})$ treatment at different concentrations over $48 \mathrm{~h}$. Plate was read $5 \mathrm{~h}$ (green dots) and $6 \mathrm{~h}$ (red dots) after alamarBlue ${ }^{\circledR}$ addition. Each dot represents mean \pm S.D. of three replicates. (B) Transport of $\left[{ }^{3} \mathrm{H}\right]$-E3S $(5 \mu \mathrm{M})$ into C2C12 wild type cells and into the new selected clone (C2C12 1B1 Cl.2). Cells were treated with (blue bars) or without (green bars) $\mathrm{NaB}$ at different concentrations $24 \mathrm{~h}$ prior the assay.

\subsubsection{Western blot analysis of C2C12 cells expressing OATP1B1}

To assess the expression of OATP1B1 at the protein level, Western blot assays were performed. As earlier attempts failed to prove the presence of OATP1B1 protein in whole cell lysates, membrane fractions were isolated from whole cell 


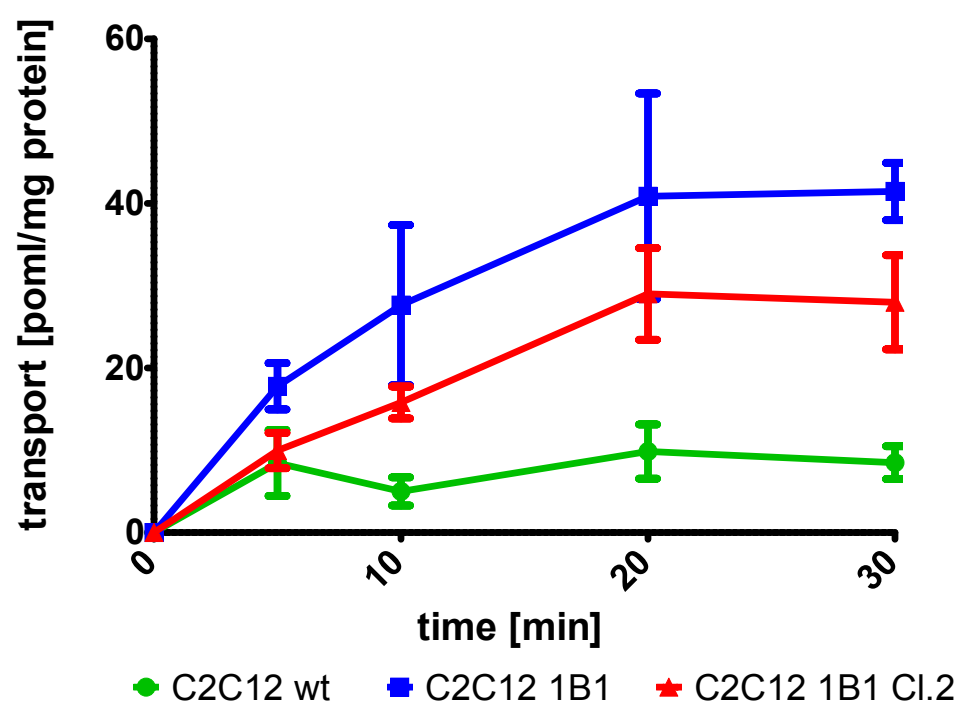

Fig. 29: Uptake of $\left[{ }^{3} \mathrm{H}\right]-\mathrm{E} 3 \mathrm{~S}$ into $\mathrm{C} 2 \mathrm{C} 12$ cells

Different clones of $\mathrm{C} 2 \mathrm{C} 12$ cells expressing OATP1B1 and control cells were tested for E3S-uptake over time. Each data point represents net-uptake values and shows mean \pm S.D. of three replicates.

lysates to enrich proteins expressed in the cell membrane and to separate them from the cytosolic fraction. Therefore, cells were harvested by scraping and membranes were prepared as described in material and methods. The Western blot analysis in Fig. 30 shows that OATP1B1 is not only expressed in the positive control CHO OATP1B1 (Fig. 30, lane 5) but also in the new clone and that expression level is not depending on $\mathrm{NaB}$ treatment (Fig. 30, lanes 3- and 3+). For the first time it was also possible to show OATP1B1 expression in the earlier selected clone (C2C12 1B1), but NaB treatment reduced expression level in this clone (Fig. 30, lanes 2- and 2+). The expected band is indicated by an arrow.
$\mathrm{M}$
$M 1-1+2-2+3-3+$
4- 4+ 5- 5+

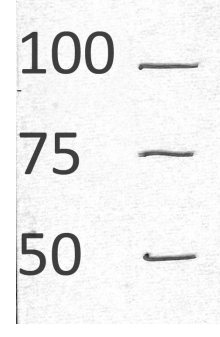

Fig. 30: Western blot analysis of membrane preparations

Total membrane fraction gained from $\mathrm{C} 2 \mathrm{C} 12$ and $\mathrm{CHO}$ wild type and transfected (OATP1B1) cells. Cells were treated with (+) or without (-) $\mathrm{NaB} 24 \mathrm{~h}$ prior harvesting. M: marker, 1: C2C12 wt, 2: C2C12 1B1; 3: C2C12 1B1 Cl.2, 4: CHO wt, 5: CHOOATP1B1 


\subsection{Statin toxicity using the C2C12 1B1 Cl.2 cells}

After identifying a clone functionally expressing OATP1B1 protein, cell viability assays were performed again to elucidate whether toxicity after statin treatment changes in the presence of a statin transporter and thus provide crucial hints on the target site of statins. To additionally find out whether statin toxicity can be reduced by inhibiting specifically OATPs/Oatps, an inhibitor was applied additionally. De Graf et al. showed ICG mediated inhibition of E3S-uptake in CHO OATP1B1 and -1B3, with $\mathrm{IC}_{50}$ values of $3.16 \mu \mathrm{M}$ and $2.35 \mu \mathrm{M}$, respectively [99]. Therefore, a concentration at least $3 x$ times higher than these $\mathrm{IC}_{50}$ values was chosen to test the hypothesis of reduced statin toxicity, when OATPs/Oatps are blocked. Briefly, C2C12 wt (wt) cells and C2C12 1B1 Cl.2 cells were treated with or without ICG $(10 \mu \mathrm{M})$ one hour prior statin treatment. Cerivastatin, atorvastatin and lipophilic rosuvastatin and pravastatin were applied at increasing concentrations. The results shown in Fig. 31 demonstrate that $\mathrm{IC}_{50}$ values differ significantly only for cells treated with cerivastatin, when comparing ICG pretreated with untreated. Here $\mathrm{IC}_{50}$ values are increased for the transfected cell lines as well as for the control cells indicating that cells pretreated with ICG are less susceptible towards cerivastatin (Tab. 13). For pravastatin and rosuvastatin, ICG did not significantly change $\mathrm{IC}_{50}$ values of both cell lines, when comparing ICG-treated with ICG-untreated samples. For Atorvastatin $\mathrm{IC}_{50}$ values are decreased, when cells were pretreated with ICG. This effect was observed in both cell lines.

\begin{tabular}{|l|r|r|r|r|}
\hline$I_{50}$ values [ $\left.\mu \mathrm{M}\right]$ & Cl. 2 w/o ICG & CI. 2 + ICG & WT w/o ICG & WT + ICG \\
\hline Cerivastatin & 0.80 & 10.26 & 0.71 & 1.29 \\
\hline Atorvastatin & 26.80 & 16.32 & no inhibition & 13.70 \\
\hline Rosuvastatin & 30.28 & 24.16 & 31.59 & 22.66 \\
\hline Pravastatin & no inhibition & no inhibition & no inhibition & no inhibition \\
\hline
\end{tabular}

Tab. 13: $\mathrm{IC}_{50}$ values of cell viability assay. Cells were treated with (+ICG) or without (w/o ICG) ICG $(10 \mu \mathrm{M})$ prior statin treatment. 

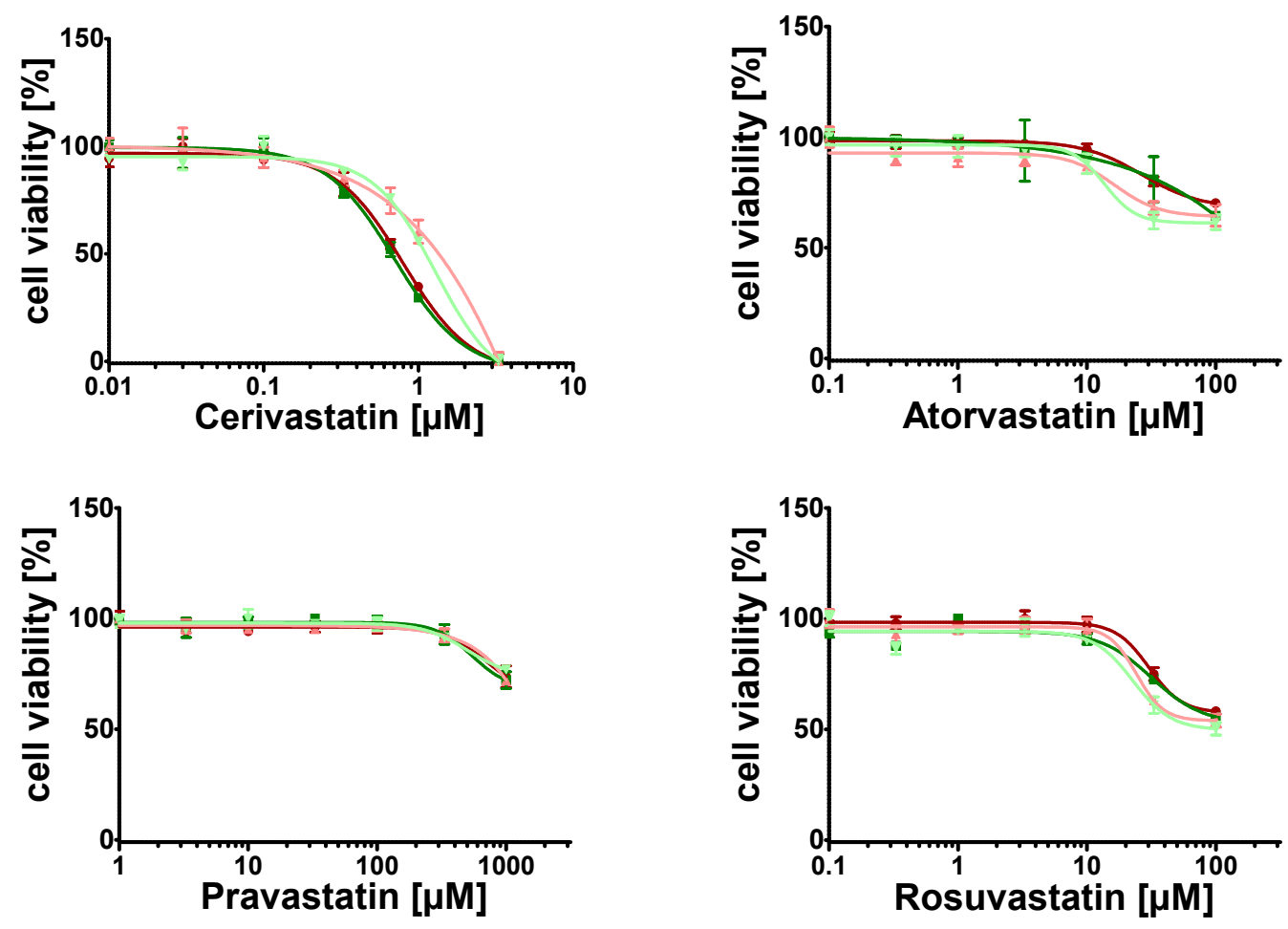

Cl. 2 w/o ICG wt w/o ICG

$\triangle$ Cl. $2+$ ICG $\nabla w t+I C G$

Fig. 31: Analysis of cell viability assays after statin treatment C2C12 wild type (wt) and OATP1B1 (Cl.2) cells were exposed to various concentrations of statins for $48 \mathrm{~h}$ and treated with or without ICG $(10 \mu \mathrm{M}) 1 \mathrm{~h}$ prior statin treatment. Cell viability was measured with alamarBlue ${ }^{\circledR}$ assay. Each data point represents the mean \pm S.D. of three replicates.

\subsection{Statin-induced apoptosis in $\mathrm{C} 2 \mathrm{C} 12$ cells}

The new developed cell model was used to elucidate whether there is a difference in statin transporter dependent toxicity for $\mathrm{C} 2 \mathrm{C} 12$ cells. Caspase-3 activity is a hallmark of apoptosis. To investigate the ability of statins to induce apoptosis an assay was setup measuring caspase- 3 activity after statin treatment. The assay uses a caspase-3-specific substrates coupled to a fluorophore, which is cleaved of by caspases-3 upon binding. The released fluorophore produces a fluorescent signal which is directly proportional to caspase-3 activity. The first step to setup this assay was to find out how long cells need to be treated with statins before caspase- 3 activity is measurable. Therefore, cells were treated with cerivastatin $(10 \mu \mathrm{M})$ for $1 \mathrm{~h}, 2 \mathrm{~h}, 4 \mathrm{~h}$ and $6 \mathrm{~h}$. Cells were subsequently lysed 
and mixed with caspase-3-specific substrate Ac-DEVD-AMC. As this assay was performed in 96-well plates suitable for fluorescent measurements, it was possible to reread the plates after a certain time to determine an appropriate substrate conversion to ensure measurements are performed in the linear phase and to obtain the best signal to noise ratio. Plates were read at $25 \mathrm{~min}, 45 \mathrm{~min}$, $60 \mathrm{~min}, 75 \mathrm{~min}, 90 \mathrm{~min}, 105 \mathrm{~min}$ (Fig. 32). As caspase-3 is strongly activated after more than $4 \mathrm{~h}$, cells were treated for $6 \mathrm{~h}$ with increasing statin concentrations. Staurosporin (300 nM) served as positive control, while negative controls were treated with solvent (DMSO).

The results presented in Fig. 33 indicate that lipophilic statin cerivastatin and simvastatin and, in part, hydrophilic rosuvastatin und pravastatin induce caspase3 activity in a dose dependent manner in C2C12 cells transfected with OATP1B1, where the strongest effect is seen in C2C12 1B1 cells. The highest dose of simvastatin $(1 \mathrm{mM})$ induced caspase- 3 activity in cells expressing OATP1B1 and in wild type cells. The data for atorvastatin are not conclusive, as caspase- 3 activity is slightly increased at $1 \mu \mathrm{M}$ and $100 \mu \mathrm{M}$ but not at $10 \mu \mathrm{M}$ in C2C12 1B1. 


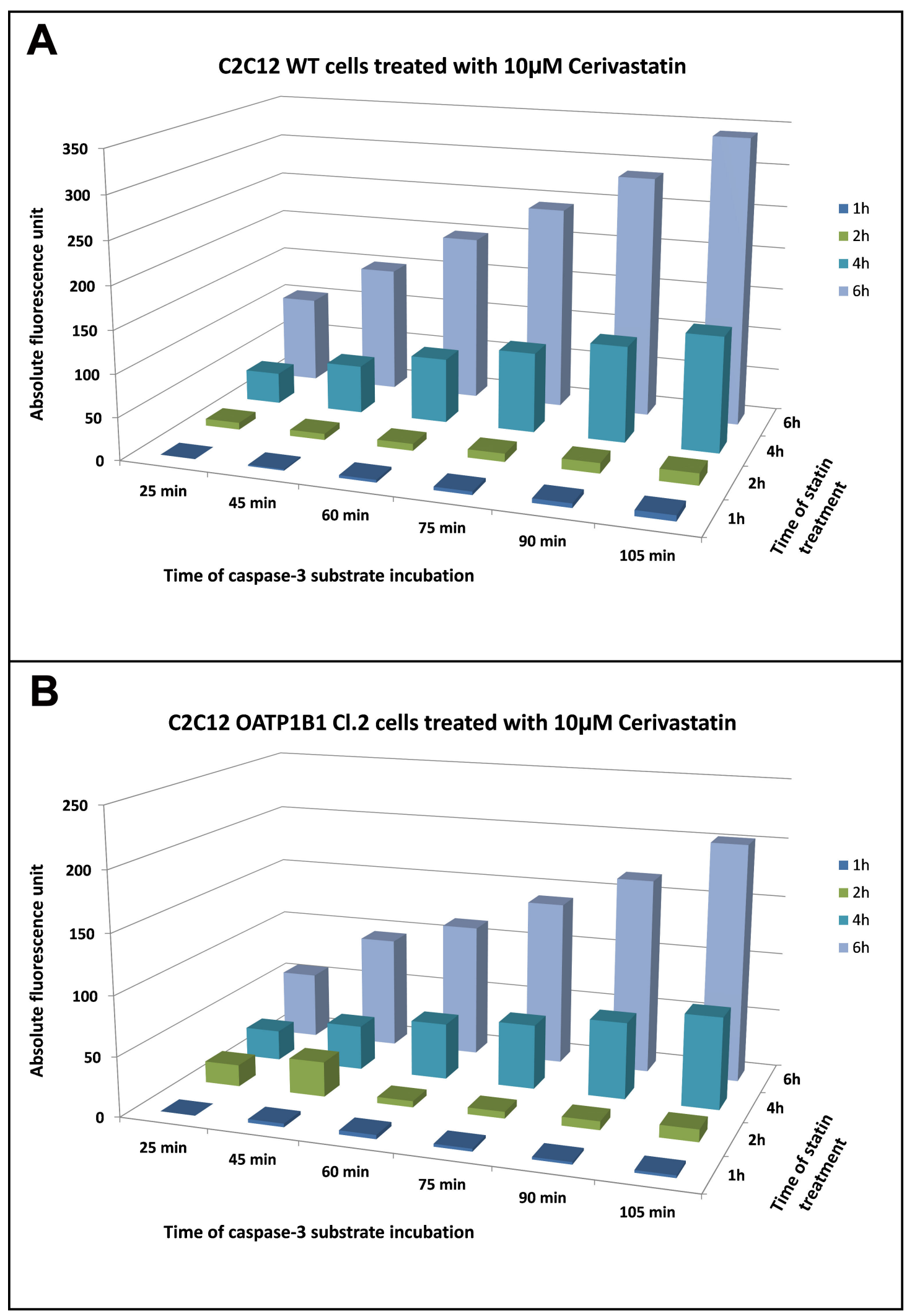

Fig. 32: Analysis of caspase-3 assay development

C2C12 wilt type cells (A) and C2C12 1B1 Cl.2 (B) where treated with $10 \mu \mathrm{M}$ cerivastatin for $1 \mathrm{~h}, 2 \mathrm{~h}, 4 \mathrm{~h}$, or $6 \mathrm{~h}$. After adding caspase- 3 substrate to the lysed cells, fluorescent measurement was performed after $25 \mathrm{~min}, 45 \mathrm{~min}, 60 \mathrm{~min}, 75 \mathrm{~min}, 90 \mathrm{~min}, 105 \mathrm{~min}$. 
Cerivastatin

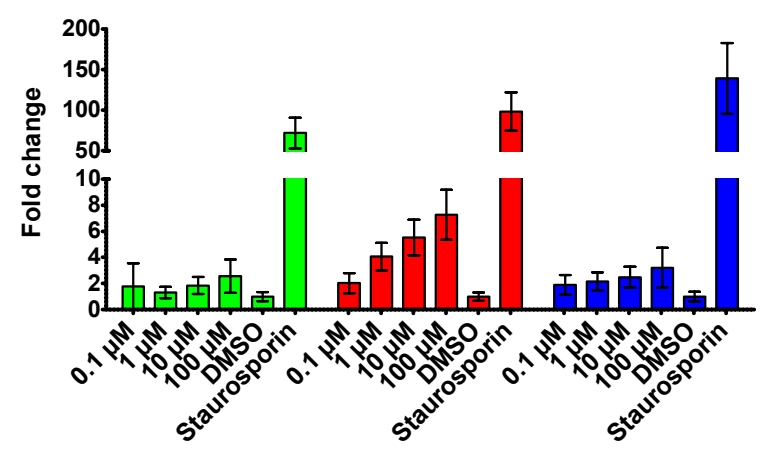

Rosuvastatin

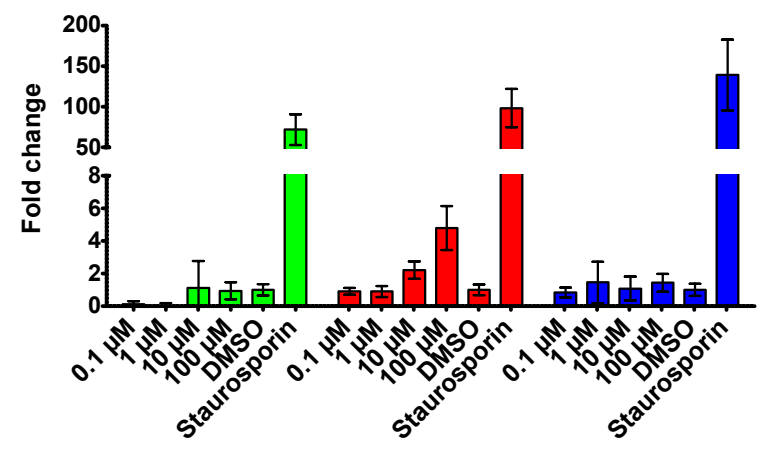

Atorvastatin

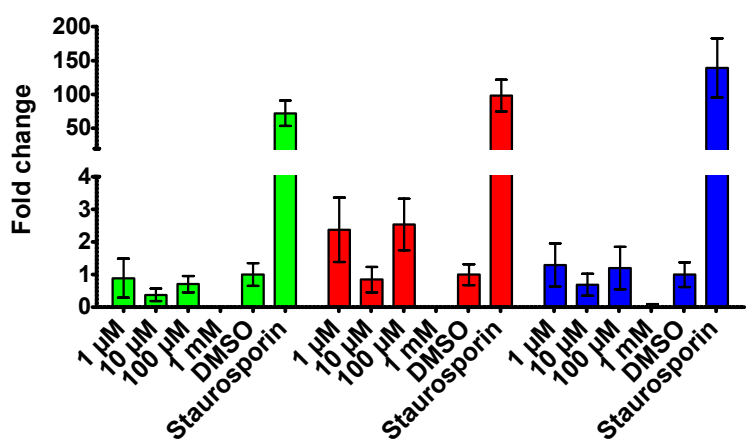

Simvastatin

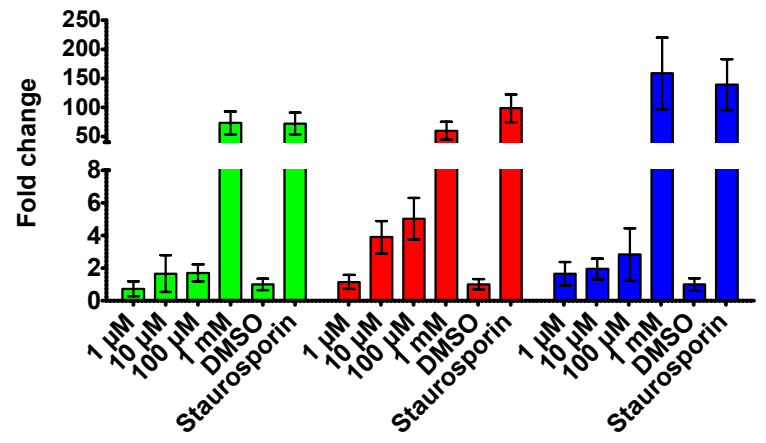

Pravastatin

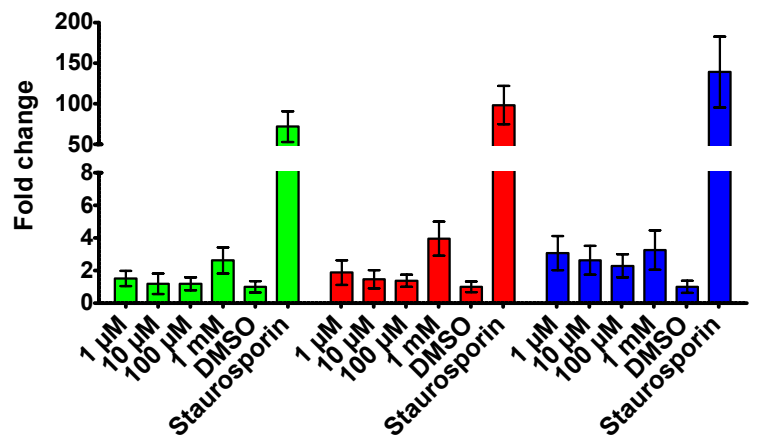

Fig. 33: Analysis of caspase-3 activity assay C2C12 wild type cells (green), C2C12 1B1 cells (red) and C2C12 1B1 $\mathrm{Cl} .2$ cells (blue) where treated for $6 \mathrm{~h}$ with different statins at the indicated concentrations. Staurosporin served as positive control. Each bar represents mean \pm S.D. of quadruplicates. 


\section{Discussion}

Today statins are key drugs for treating hypercholesterolemia and play an essential role in the primary and secondary prevention of cardiovascular disease. In the future the number of patients receiving statins is likely to increase as latest research is investigating the potential of statins in breast cancer treatment and as statins have been shown to reduce the risk to develop hepatocellular cancer $[100,101]$. Additionally, statins were recently shown to reduce cardiovascular events even in "patients" with "normal" LDL levels [102]. Although statins have a favorable safety profile and have well documented benefits to patients with cardiovascular disease, their adverse effects are neither negligible nor do they have trivial consequences. Statins have several potential adverse effects, mostly related to myopathies. In rare cases statin-induced myopathies can lead to the dissolution of the skeletal muscle cells (rhabdomyolysis).

Therefore, understanding the etiology of statin-induced myopathies and the exact mechanism behind is an area of increasing importance. Various in vivo and in vitro models have shown that statins directly induce toxicity in muscle cells $[37,40,103-105]$. The exact mechanism how statins induce toxicity in muscle cells still needs to be clarified. It is currently not known to full detail whether cytotoxic effects of statins on muscle cells originate at the plasma membrane or are initiated intracellularly. Here, statin transporters might influence local statin concentrations and play a crucial role in statin-induced myotoxicity [28]. Based on the present state of knowledge, this $\mathrm{PhD}$ thesis aimed to expand the knowledge of how statins induce myopathies, by investigating the role of uptake systems in statin-induced myotoxicity. To identify the relevance of uptake transporters to the in vivo activity of statins, an in vitro tool was established which allows studying the influence of uptake transporters on statin toxicity in muscle cells. Therefore, skeletal muscle cells stably expressing the main uptake transporters of statins into human liver were established. The skeletal muscle 
cell lines L6 (rat) and C2C12 (mouse) were transfected with the hepatocellular statin transporter OATP1B1 or OATP1B3. The transfected cells as well as the non-muscle cell line $\mathrm{CHO}$ were then used to study the effect of statins on cell viability and the potential to induce apoptosis. After the transfection, it was possible to isolate a clone of the cell line $\mathrm{C} 2 \mathrm{C} 12$ stably transfected with OATP1B1 by functional testing (C2C12 1B1). This clone showed transport activity of the OATP model substrate E3S (Fig. 11). Cell viability studies after statin treatment revealed no difference in toxicity between the wild type and transfected cells. To elucidate whether muscle cells are per se more sensitive towards statins than non-muscle cells, the fibroblast cell lines $\mathrm{CHO}$ expressing OATP1B1, -1B3, or -2B1 and the wild type cells were compared with the skeletal muscle cell lines $\mathrm{C} 2 \mathrm{C} 12$ and L6. Results indicate that muscle cells are indeed more susceptible towards statins as non-muscle cells. The expression of the statin transporters OATP1B1, -1B3, or -2B1 in CHO cells had no influence on cytotoxicity after statin treatment. As it was not possible to demonstrate the expression of the carrier at protein and RNA level, L6 and C2C12 cells were transfected again, using a different vector. The new transfection yielded a clone (C2C12 1B1, Cl.2), which is functional active, based on data of E3S uptake (Fig. 29). It was also possible to demonstrate the expression of OATP1B1 at RNA and protein level. With the new clone it was possible to demonstrate that certain statins induce apoptosis in a transporter dependent manner 33. The decision to directly screen for functional active clones with the cellular uptake assay was based on earlier experience with stable transfection experiments in the lab $[61,80]$. In this first round of transfection it was possible to identify a clone showing consistently transport of the OATP model substrate E3S (C2C12 1B1) and the hydrophilic pravastatin, which exceeded uptake into wild type cells by about factor five (Fig. 29, Fig. 14). To further characterize the selected clone C2C12 1B1, it was tried to localize OATP1B1 at the subcellular level using CLSM. The signal from C2C12 1B1 samples was distributed all over the cell, while the CHO OATP1B1 sample showed a clear localization of OATP1B1 to the plasma membrane (Fig. 18). One could now speculate whether this signal is the result of mistargeted proteins, which are dispersed in intracellular organells, or whether it represents background due to the increased laser power. Although different antibodies were tested and several parameters during sample preparation were changed, it was not possible to definitely localize OATP1B1 to the plasma membrane and thus demonstrating its proper integration in the plasma 
membrane. This is in contradiction to the results from transport experiments. Using Western blotting and qRT-PCR analysis, it was also not possible to show the expression of OATP1B1. It was suggested, that part of the translated protein at the C-terminal end is missing, which maybe has no influence on the functionality of OATP1B1. This hypothesis could be excluded as different antibodies were tested, targeting the middle region or the N-terminal region of OATP1B1. In these tests it was also not possible to demonstrate the expression of OATP1B1. These data are very conflicting as on the one hand it was possible to reproducibly show the expression of a transporter at a functional level and on the other hand it was not possible to demonstrate the expression of OATP1B1 on RNA or protein level. One can only speculate about the reason of this phenomenon. During transfection the plasmid DNA gets integrated randomly into the genome of the host cell. This integration could lead to the disruption of repressor elements regulating the expression of endogenous uptake systems, which in turn leads to an enhanced expression of transporters responsible for the uptake of the tested substrates. It might therefore be possible that $\mathrm{C} 2 \mathrm{C} 12 \mathrm{en}-$ dogenously expresses Oatps, which became upregulated somehow through the process of transfection. Slco1b2 and Slco2b1 are known orthologues of the human OATPs OATP1B1 and OATP2B1, respectively. At least OATP2B1 is known to be expressed at the sarcolemmal membrane of human skeletal muscle fibers [53]. Proteins of Slco1b2 and Slco2b1 are not expressed in wild type C2C12 and L6 cells, which were tested during this work using qRT-PCR (data not shown). Additionally, our data show that $\mathrm{C} 2 \mathrm{C} 12$ cells take up statins to a larger extent compared to $\mathrm{CHO}$ cells, which indicates that the barrier function in muscle cells is different from non-muscle cells (Fig. 14). These data are in accordance with the data of the cell viability test, where $\mathrm{CHO}$ and muscle cells were compared after statin treatment, demonstrating a higher susceptibility of muscle cells towards statins compared to the non-muscle fibroblasts (Fig. 5).

Although several studies were performed with the initially selected clone, L6 and $\mathrm{C} 2 \mathrm{C} 12$ cells were transfected again using a different vector previously shown to work with $\mathrm{C} 2 \mathrm{C} 12$ and L6 cells, namely pcDNA3.1. Another reason for switching the vector was that pcDNA3.1 contains a polyadenylation site, which improves mRNA stability (Fig.3). The previously used vector pIRESneo2 contained a synthetic intron to stabilize the mRNA [95]. Having learned that high functionality does not directly mean high protein expression, the strategy to 
successfully find a clone expressing OATP1B1 or -1B3 and simultaneously being highly active in the transport assay was adapted. For the new transfections, functional screening was paralleled with gene expression analysis using qRTPCR. This new strategy enabled the identification of a functional active clone, which also shows expression of the respective mRNA (Fig. 26). With a new established method it was additionally possible to demonstrate the expression of OATP1B1 on protein level, not only in the new clone C2C12 1B1 Cl.2, but also for the first time in the earlier selected clone C2C12 1B1 (Fig. 30). Reason for this might be the general low expression level of this transporter after transfection in this cell system.

The previously performed toxicity studies with statins where now repeated with the new clone C2C12 1B1 C1.2. To inhibit OATP1B1, ES3 sulfate was replaced by ICG, which was previously shown to act as inhibitor of OATP1B1 but not as substrate [95]. The results obtained in this test (Fig. 31) are similar to the previously obtained results with the earlier clone (Fig. 16, Fig. 17). These tests revealed that there is no difference in toxicity when comparing C2C12 1B1 $\mathrm{Cl} .2$ and wild type cells. One possible explanation could be that the time point (48h) of measuring the cell viability is too late. The cell viability assay measures the reducing power of living cells and to clearly recognize differences in treated and control groups, cells need to be treated for at least $48 \mathrm{~h}$ with a toxin. As transport rates of OATPs are up to several $\mathrm{nmol} / \mathrm{mg}$ protein $\cdot \mathrm{min}^{-} 1$ and as C2C12 wild type cells probably also express Oatps, chances are high that statins get inside the cell and reach steady state already after a few hours. Additionally, chances are quite high for lipophilic statins to penetrate the plasma membrane during this long lapse of time and induce toxicity inside the cell. On the other hand our data show at least for cerivastatin that toxicity is reduced, when OATPs/Oatps are blocked with ICG, supporting the concept that statins need to be taken up in a transporter dependent manner and induce toxicity from inside the cell. Atorvastatin, rosuvastatin and pravastatin should have had been tested at higher concentrations, which was not possible due to their solubility limit. As the cell viability assay is looking at a very late stage of cell death, an assay was setup to investigate an early marker of apoptosis after statin treatment. Activation of caspase- 3 is a hallmark of apoptosis and is induced already after several hours of treatment with an apoptotic toxin [106, 107]. Cerivastatin, simvastatin and rosuvastatin nicely show a concentration dependent induction of caspase-3 in C2C12 1B1 cells and not in the control cells, which shows the 
necessity of a transport system to induce apoptosis. Studies investigating the potential of statins to induce caspase- 8 and caspase- 9 in C2C12 1 B1 cells also suggest a role of transport proteins, i.e. intracellular action of the statins, but data were not reproducibly conclusive (data not shown). Taken together, these results indicate that myotoxicity is induced by intracellular toxicity of statins.

Interestingly it was not possible to show the induction of caspase- 3 in pravastatin treated cells. In the assays used in this work, pravastatin showed only slight cell toxicity and caspase-3 activation at the highest tested concentration $(1 \mathrm{mM})$ in C2C12 cells. This is not in accordance with clinically observed muscle toxicities induced by pravastatin, which has a similar incidence as atorvastatin and simvastatin [108]. Reason for this could be that pravastatin has a different mechanism to induce toxicity and that the established in vitro system is lacking the toxicity-target of pravastatin, which is only apparent in the in vivo situation. Another explanation for this phenomenon could be that a metabolite of pravastatin is the elicitor and that $\mathrm{C} 2 \mathrm{C} 12$ cells are an inappropriate test system to investigate toxicity for this particular statin. The effect of medium $\mathrm{pH}$ on the statin transport has been investigated only to a minor extent. It is well established that OATPs generally exhibit higher transport rates under low extracellular $\mathrm{pH}[109,110]$. The group of Iseki et. al demonstrated an increased uptake of rosuvastatin under acidic medium conditions using rat L6 and human RD cells [111]. As the interstitial pH of skeletal muscle during exercises is decreased [111] the question came up whether transport rates of statins change under acidic conditions. Therefore, the relationship between pravastatin-, cerivastatin- and simvastatin-transport and medium $\mathrm{pH}$ was examined. The uptake under acidic conditions ( $\mathrm{pH}$ 6.5) revealed that transport rates were significantly increased only for cerivastatin compared to the physiological conditions ( $\mathrm{pH}$ 7.4). For pravastatin, there was only a trend to higher uptake rates under acidic conditions. These results may provide an indication why muscle tissue is at higher risk to show toxicity symptoms after statin treatment. 


\section{Conclusion}

In conclusion, the results of this work contribute to understanding the mechanism of how statins induce myotoxicity. The role of an uptake system in statininduced rhabdomyolysis cannot be neglected. Although the exact uptake system in skeletal muscle cells responsible for statin uptake could not be identified, the results of this work indicate that statins need to be taken up into the cell to induce cell toxicity and the cytotoxic action of statins from the outside of cells does not explain completely statin myotoxicity. An inhibition of this uptake system can reduce toxicity to a certain degree. During the work of this thesis a model system was established, allowing investigations of compounds being an OATP substrate and their influence on myoblasts.

\section{Outlook}

HMG-CoA reductase acts early in the mevalonate pathway and thus inhibition also interfere with the synthesis of many non-steroidal isoprenoid molecules. Therefore, it is preferable to prevent the cholesterol biosynthesis by targeting an enzyme, which lies downstream of farnesyl pyrophosphate in the cholesterol biosynthesis pathway, without interrupting the biosynthesis of essential physiological components, such as ubiquinone and dolichol. Investigations to find other drugs to treat hypercholesterolemia which act further downstream in cholesterol synthesis looked promising at the beginning. Takeda pharmaceutical tried to inhibit squalene synthase (Fig. 1), not to disturb the mevalonate pathway, with lapaquistat acetate. In 2008 the development of this compound was discontinued "...based on judgment that the profile of the compound is not superior to existing marketed drugs from both efficacy and safety viewpoints." [112]. Another promising candidate is zaragozic acid, which is currently discussed and reviewed $[113,114]$. Zaragozic acids are a family of fungal metabolites and act as inhibitors of squalene synthase. Interestingly, family members of zaragozic acid have been identified as ras farnesyl transferase and geranylgeranyl transferases inhibitors [115], which consequently would inhibit ubiquinone and dolichol production (Fig. 1). In 2013 a Japanese group published the structure of a lead compound acting as squalene synthase inhibitor and demonstrated their in vivo efficacy and liver selectivity [116]. Nevertheless, no compound focusing 
on the inhibition of the squalene-cholesterol branch has done it to the market so far, but recent publications look promising to find a new class of pharmaceuticals to treat hypercholesterolemia. 



\section{ACKNOWLEDGEMENTS}

I was given a PhD position by the University Hospital Zurich joining the Departement of Clinical Pharmacology and Toxicology in Oktober 2010. I was enrolled into the PhD program Prodoc at the University of Zurich. In the last four years of research I had the freedom to investigate and carry out experiments in an independent manner. I thank my thesis committee Prof. Dr. Michael "Erni" Arand, Prof. Dr. Bruno Stieger, Prof. Dr. Raimund Dutzler for their support and guidance through out my PhD. Thank you for all the fruitful discussion we had. Especially, I am grateful to have Prof. Stieger as my direct supervisor who always had a solution for any kind of problems. When ever he was in Zurich and not giving a talk at the other side of the world, he came over to the lab in the morning and asked the people if something needs to be discussed or someone needs his support. I really appreciated that Bruno. It was fantastic to sit down with Prof. Stieger and discussing with him not only the science. He was very supporting and guiding me through out the project with all its highs and lows. A big thank to Prof. Dr. Gerd Kullak-Ublick, for giving me the opportunity to do my $\mathrm{PhD}$ in his department. I also like to thank all the people participating in the Prodoc programm. It was a pleasure getting to know you and I really appreciate the time we spent together at the monthly seminars and our retreats in the alps. I also like to thank my colleagues Mayank Chaubey, Michele Visentin, Christian Hiller, Zainab Mahdi, Ma Li, Jessica Mwinyj, Lia Hofstetter, Carlos Schaffner, Katrin Wlcek, GaiZhibo, Tatiana Claro da Silva, Ragam Attinkara, Marisa Leu and all I forgot to mention.

Finally I want to thank my family, especially my parents Ralf and Bärbel for supporting me during my studies and their guidance through out my whole life. I am also deeply grateful to my girl friend Doris Pöhlmann who always stood behind me, followed me to Switzerland and gave birth to our beautiful son Tarje in March 2014. 



\section{PUBLICATIONS and AWARDS}

\section{PUBLICATIONS}

Christian Feuerstacke, Bruno Stieger

Role of skeletal muscle transport systems in statin-induced myotoxicity

Toxicology Letters, Volume 221, Supplement, 28 August 2013, Page S77

doi:10.1016/j.toxlet.2013.05.071

\section{AWARDS}

2013 YOUNG SCIENTIST AWARD

"Highly Commended Poster Presentation Recognition" awarded by the Federation of European Toxicologists and European Societies of Toxicology 



\section{REFERENCES}

[1] Cholesterol Treatment Trialists et al. Efficacy and safety of cholesterollowering treatment: prospective meta-analysis of data from 90056 participants in 14 randomised trials of statins. The Lancet, 366(9493):1267-1278, 2005.

[2] Irina Buhaescu and Hassane Izzedine. Mevalonate pathway: a review of clinical and therapeutical implications. Clinical biochemistry, 40(9):575584, 2007.

[3] Eva S Istvan and Johann Deisenhofer. Structural mechanism for statin inhibition of hmg-coa reductase. Science, 292(5519):1160-1164, 2001.

[4] Fergus McTaggart, Linda Buckett, Robert Davidson, Geoffry Holdgate, Alex McCormick, Dennis Schneck, Graham Smith, and Michael Warwick. Preclinical and clinical pharmacology of rosuvastatin, a new 3-hydroxy3-methylglutaryl coenzyme a reductase inhibitor. The American journal of cardiology, 87(5):28-32, 2001.

[5] GA Holdgate, WHJ Ward, and F McTaggart. Molecular mechanism for inhibition of 3-hydroxy-3-methylglutaryl coa (hmg-coa) reductase by rosuvastatin. Biochemical Society Transactions, 31(3):528-531, 2003.

[6] Michael S Brown and Joseph L Goldstein. A receptor-mediated pathway for cholesterol homeostasis. Science, 232(4746):34-47, 1986.

[7] Pascal Sirvent, Jacques Mercier, and Alain Lacampagne. New insights into mechanisms of statin-associated myotoxicity. Current opinion in pharmacology, 8(3):333-338, 2008. 
[8] Christos Vaklavas, Yiannis S Chatzizisis, Anthony Ziakas, Chrysanthos Zamboulis, and George D Giannoglou. Molecular basis of statinassociated myopathy. Atherosclerosis, 202(1):18-28, 2009.

[9] IMS Health. Top 25 u.s. pharmaceutical products by dispensed prescriptions, 2012. URL http://www.imshealth.com/deployedfiles/ ims/Global/Content/Corporate/Press\%20Room/Top-Line\%20Market\% 20Data\%20\&\%20Trends/2011\%20Top-line\%20Market\%20Data/Top_ Products_by_RX.pdf.

[10] Michael H Davidson. Safety profiles for the hmg-coa reductase inhibitors. Drugs, 61(2):197-206, 2001.

[11] Sivakumar Sathasivam. Statin induced myotoxicity. European journal of internal medicine, 23(4):317-324, 2012.

[12] Richard C Pasternak, Sidney C Smith, C Noel Bairey-Merz, Scott M Grundy, James I Cleeman, and Claude Lenfant. Acc/aha/nhlbi clinical advisory on the use and safety of statins12. Journal of the American College of Cardiology, 40(3):567-572, 2002.

[13] Abdulsalam A Al-Sulaiman, Nora I Al-Muslim, Abdulaziz A Al-Quorain, and Raed M Al-Sulaiman. The self-limiting nature of statin-induced rhabdomyolysis. Journal of family $\mathcal{E}$ community medicine, 16(3):119, 2009.

[14] Kenneth A Antons, Craig D Williams, Steven K Baker, and Paul S Phillips. Clinical perspectives of statin-induced rhabdomyolysis. The American journal of medicine, 119(5):400-409, 2006.

[15] Paul D Thompson, Priscilla Clarkson, and Richard H Karas. Statinassociated myopathy. Jama, 289(13):1681-1690, 2003.

[16] Rohit Arora, Max Liebo, and Frank Maldonado. Statin-induced myopathy: the two faces of janus. Journal of cardiovascular pharmacology and therapeutics, 11(2):105-112, 2006.

[17] Anneke Nina Werk and Ingolf Cascorbi. Functional gene variants of cyp3a4. Clinical Pharmacology \& Therapeutics, 96(3):340-348, 2014.

[18] Wolfgang Sadee. Gene-gene-environment interactions between drugs, transporters, receptors, and metabolizing enzymes: Statins, slco1b1, and 
cyp3a4 as an example. Journal of pharmaceutical sciences, 102(9):2924-2929, 2013.

[19] Marja K Pasanen, Mikko Neuvonen, Pertti J Neuvonen, and Mikko Niemi. Slco1b1 polymorphism markedly affects the pharmacokinetics of simvastatin acid. Pharmacogenetics and genomics, 16(12):873-879, 2006.

[20] Rommel G Tirona, Brenda F Leake, Gracia Merino, and Richard B Kim. Polymorphisms in oatp-c identification of multiple allelic variants associated with altered transport activity among european-and africanamericans. Journal of Biological Chemistry, 276(38):35669-35675, 2001.

[21] Jae-Yong Chung, Joo-Youn Cho, Kyung-Sang Yu, Jung-Ryul Kim, DalSeok Oh, Hye-Ryung Jung, Kyoung-Soo Lim, Ki-Ho Moon, Sang-Goo Shin, and In-Jin Jang. Effect of oatp1b1 (slco1b1) variant alleles on the pharmacokinetics of pitavastatin in healthy volunteers. Clinical Pharmacology \& Therapeutics, 78(4):342-350, 2005.

[22] Mikko Niemi, Marja K Pasanen, and Pertti J Neuvonen. Organic anion transporting polypeptide 1b1: a genetically polymorphic transporter of major importance for hepatic drug uptake. Pharmacological reviews, 63(1): 157-181, 2011.

[23] Matthew A Silva, Anna C Swanson, Pritesh J Gandhi, and Gary R Tataronis. Statin-related adverse events: a meta-analysis. Clinical therapeutics, 28(1):26-35, 2006.

[24] Curt D. Furberg and Bertram Pitt. Withdrawal of cerivastatin from the world market. Curr Control Trials Cardiovasc Med, 2(5):205-207, 2001.

[25] PETER F Smith, RONALD S Eydelloth, SCOTT J Grossman, R JOHN Stubbs, MICHAEL S Schwartz, JI Germershausen, KP Vyas, PH Kari, and JS MacDonald. Hmg-coa reductase inhibitor-induced myopathy in the rat: cyclosporine a interaction and mechanism studies. Journal of Pharmacology and Experimental Therapeutics, 257(3):1225-1235, 1991.

[26] Peter JK Gruer, Jose M Vega, Michele F Mercuri, Michael R Dobrinska, and Jonathan A Tobert. Concomitant use of cytochrome p450 3a4 inhibitors and simvastatin. The American journal of cardiology, 84(7):811-815, 1999. 
[27] Annick Seithel, Sonja Eberl, Katrin Singer, Daniel Auge, Georg Heinkele, Nadine B Wolf, Frank Dörje, Martin F Fromm, and Jörg König. The influence of macrolide antibiotics on the uptake of organic anions and drugs mediated by oatp1b1 and oatp1b3. Drug metabolism and disposition, 35(5): 779-786, 2007.

[28] A Kalliokoski and M Niemi. Impact of oatp transporters on pharmacokinetics. British journal of pharmacology, 158(3):693-705, 2009.

[29] Karen E Hansen, Julie P Hildebrand, Edwin E Ferguson, and James H Stein. Outcomes in 45 patients with statin-associated myopathy. Archives of internal medicine, 165(22):2671-2676, 2005.

[30] Georgirene D Vladutiu, Zachary Simmons, Paul J Isackson, Mark Tarnopolsky, Wendy L Peltier, Alexandru C Barboi, Naganand Sripathi, Robert L Wortmann, and Paul S Phillips. Genetic risk factors associated with lipid-lowering drug-induced myopathies. Muscle \& nerve, 34(2):153$162,2006$.

[31] Peter James Mullen, Barbara Lüscher, Hubert Scharnagl, Stephan Krähenbühl, and Karin Brecht. Effect of simvastatin on cholesterol metabolism in c2c12 myotubes and hepg2 cells, and consequences for statin-induced myopathy. Biochemical pharmacology, 79(8):1200-1209, 2010.

[32] Oliver P Flint, Barbara A Masters, Richard E Gregg, and Stephen K Durham. Inhibition of cholesterol synthesis by squalene synthase inhibitors does not induce myotoxicityin vitro. Toxicology and applied pharmacology, 145(1):91-98, 1997.

[33] Sumio Matzno, Takeshi Yamauchi, Maki Gohda, N Ishida, Kimio Katsuura, Yasuaki Hanasaki, Takumi Tokunaga, Hiroyuki Itoh, and Norifumi Nakamura. Inhibition of cholesterol biosynthesis by squalene epoxidase inhibitor avoids apoptotic cell death in 16 myoblasts. Journal of lipid research, 38(8):1639-1648, 1997.

[34] Douglas J Norman, D Roger Illingworth, Jennifer Munson, and Jeffrey Hosenpud. Myolysis and acute renal failure in a heart-transplant recipient receiving lovastatin. The New England journal of medicine, 318(1):46-47, 1988. 
[35] Steven K Baker. Molecular clues into the pathogenesis of statin-mediated muscle toxicity. Muscle E nerve, 31(5):572-580, 2005.

[36] Bernd Moosmann and Christian Behl. Selenoprotein synthesis and sideeffects of statins. The Lancet, 363(9412):892-894, 2004.

[37] P Kaufmann, M Török, A Zahno, KM Waldhauser, K Brecht, and $S$ Krähenbühl. Toxicity of statins on rat skeletal muscle mitochondria. Cellular and Molecular Life Sciences CMLS, 63(19-20):2415-2425, 2006.

[38] Andrew L Mammen and Anthony A Amato. Statin myopathy: a review of recent progress. Current opinion in rheumatology, 22(6):644-650, 2010.

[39] Takeharu Ogura, Yoshiyuki Tanaka, Tetsushi Nakata, Tomoko Namikawa, Hirofumi Kataoka, and Yoshikazu Ohtsubo. Simvastatin reduces insulin-like growth factor-1 signaling in differentiating c2c12 mouse myoblast cells in an hmg-coa reductase inhibition-independent manner. The Journal of toxicological sciences, 32(1):57-67, 2007.

[40] Peirang Cao, Jun-ichi Hanai, Preeti Tanksale, Shintaro Imamura, Vikas P Sukhatme, and Stewart H Lecker. Statin-induced muscle damage and atrogin-1 induction is the result of a geranylgeranylation defect. The FASEB Journal, 23(9):2844-2854, 2009.

[41] Fang L Zhang and Patrick J Casey. Protein prenylation: molecular mechanisms and functional consequences. Annual review of biochemistry, 65(1): 241-269, 1996.

[42] Sumio Matzno, Shinya Yasuda, Sachiko Juman, Yukiko Yamamoto, Noriko Nagareya-Ishida, Toshikatsu Nakabayashi, Kenji Matsuyama, and Keiko Tazuya-Murayama. Statin-induced apoptosis linked with membrane farnesylated ras small g protein depletion, rather than geranylated rho protein. Journal of pharmacy and pharmacology, 57(11):1475-1484, 2005.

[43] Kazuho Sakamoto, Takashi Honda, Sachihiko Yokoya, Satoshi Waguri, and Junko Kimura. Rab-small gtpases are involved in fluvastatin and pravastatin-induced vacuolation in rat skeletal myofibers. The FASEB Journal, 21(14):4087-4094, 2007. 
[44] Cecilia Östlund and Howard J Worman. Nuclear envelope proteins and neuromuscular diseases. Muscle \& nerve, 27(4):393-406, 2003.

[45] Lawrence A Beck, Theresa J Hosick, and Michael Sinensky. Isoprenylation is required for the processing of the lamin a precursor. The Journal of cell biology, 110(5):1489-1499, 1990.

[46] Jan Lammerding, P Christian Schulze, Tomosaburo Takahashi, Serguei Kozlov, Teresa Sullivan, Roger D Kamm, Colin L Stewart, and Richard T Lee. Lamin a/c deficiency causes defective nuclear mechanics and mechanotransduction. Journal of Clinical Investigation, 113(3):370, 2004.

[47] Gregory J Warner, Marla J Berry, Mohamed E Moustafa, Bradley A Carlson, Dolph L Hatfield, and Jerry R Faust. Inhibition of selenoprotein synthesis by selenocysteine trna [ser] sec lacking isopentenyladenosine. Journal of Biological Chemistry, 275(36):28110-28119, 2000.

[48] Sanjay Kalra. The role of coenzyme q10 in statin-associated myopathy. Electronic Physician, 1:2-8, 2009.

[49] Berthold B Schalke, Beate Schmidt, Klaus Toyka, and Hans-Peter Hartung. Pravastatin-associated inflammatory myopathy. New England Journal of Medicine, 327(9):649-650, 1992.

[50] Douglas B Kell and Stephen G Oliver. How drugs get into cells: tested and testable predictions to help discriminate between transporter-mediated uptake and lipoidal bilayer diffusion. Frontiers in pharmacology, 5, 2014.

[51] Michio Takeda, Rie Noshiro, Maristela Lika Onozato, Akihiro Tojo, Habib Hasannejad, Xiu-Lin Huang, Shinichi Narikawa, and Hitoshi Endou. Evidence for a role of human organic anion transporters in the muscular side effects of hmg-coa reductase inhibitors. European journal of pharmacology, 483(2):133-138, 2004.

[52] K Sakamoto, H Mikami, and J Kimura. Involvement of organic anion transporting polypeptides in the toxicity of hydrophilic pravastatin and lipophilic fluvastatin in rat skeletal myofibres. British journal of pharmacology, 154(7):1482-1490, 2008.

[53] Michael J Knauer, Bradley L Urquhart, Henriette E Meyer zu Schwabedissen, Ute I Schwarz, Christopher J Lemke, Brenda F Leake, Richard B 
Kim, and Rommel G Tirona. Human skeletal muscle drug transporters determine local exposure and toxicity of statins. Circulation research, 106 (2):297-306, 2010.

[54] Kathleen M Giacomini, Shiew-Mei Huang, Donald J Tweedie, Leslie Z Benet, Kim LR Brouwer, Xiaoyan Chu, Amber Dahlin, Raymond Evers, Volker Fischer, Kathleen M Hillgren, et al. Membrane transporters in drug development. Nature reviews Drug discovery, 9(3):215-236, 2010.

[55] Naomi Mizuno, Takuro Niwa, Yoshihisa Yotsumoto, and Yuichi Sugiyama. Impact of drug transporter studies on drug discovery and development. Pharmacological reviews, 55(3):425-461, 2003.

[56] Fabienne Meier-Abt, Younes Mokrab, and Kenji Mizuguchi. Organic anion transporting polypeptides of the oatp/slco superfamily: identification of new members in nonmammalian species, comparative modeling and a potential transport mode. The Journal of membrane biology, 208(3): 213-227, 2006.

[57] Bruno Stieger and Bruno Hagenbuch. Organic anion-transporting polypeptides. Curr Top Membr, 73:205-232, 2014. doi: 10. 1016/B978-0-12-800223-0.00005-0. URL http://dx.doi.org/10.1016/ B978-0-12-800223-0.00005-0.

[58] Emmanuel Jacquemin, Bruno Hagenbuch, Bruno Stieger, Allan W Wolkoff, and Peter J Meier. Expression cloning of a rat liver na (+)-independent organic anion transporter. Proceedings of the National Academy of Sciences, 91(1):133-137, 1994.

[59] Gerd A Kullak-Ublick, Bruno Hagenbuch, Bruno Stieger, Claudio D Schteingart, Alan F Hofmann, Allan W Wolkoff, and Peter J Meier. Molecular and functional characterization of an organic anion transporting polypeptide cloned from human liver. Gastroenterology, 109(4):1274-1282, 1995.

[60] Bo Gao, Bruno Hagenbuch, Gerd A Kullak-Ublick, Dietmar Benke, Adriano Aguzzi, and Peter J Meier. Organic anion-transporting polypeptides mediate transport of opioid peptides across blood-brain barrier. Journal of Pharmacology and Experimental Therapeutics, 294(1):73-79, 2000. 
[61] Chunshan Gui, Yi Miao, Lucas Thompson, Bret Wahlgren, Melissa Mock, Bruno Stieger, and Bruno Hagenbuch. Effect of pregnane $\mathrm{x}$ receptor ligands on transport mediated by human oatp1b1 and oatp1b3. European journal of pharmacology, 584(1):57-65, 2008.

[62] Megan Roth, Juan J Araya, Barbara N Timmermann, and Bruno Hagenbuch. Isolation of modulators of the liver-specific organic aniontransporting polypeptides (oatps) $1 \mathrm{~b} 1$ and $1 \mathrm{~b} 3$ from rollinia emarginata schlecht (annonaceae). Journal of Pharmacology and Experimental Therapeutics, 339(2):624-632, 2011.

[63] Simone Leuthold, Bruno Hagenbuch, Nilufar Mohebbi, Carsten A Wagner, Peter J Meier, and Bruno Stieger. Mechanisms of ph-gradient driven transport mediated by organic anion polypeptide transporters. American Journal of Physiology-Cell Physiology, 296(3):C570-C582, 2009.

[64] Takashi Nozawa, Kozue Imai, Jun-Ichi Nezu, Akira Tsuji, and Ikumi Tamai. Functional characterization of ph-sensitive organic anion transporting polypeptide oatp-b in human. Journal of Pharmacology and Experimental Therapeutics, 308(2):438-445, 2004.

[65] Simone Leuthold, Bruno Hagenbuch, Nilufar Mohebbi, Carsten A Wagner, Peter J Meier, and Bruno Stieger. Mechanisms of ph-gradient driven transport mediated by organic anion polypeptide transporters. American Journal of Physiology-Cell Physiology, 296(3):C570-C582, 2009.

[66] Biochim Hagenbuch and PJ Meier. The superfamily of organic anion transporting polypeptides. Biochimica et Biophysica Acta (BBA)Biomembranes, 1609(1):1-18, 2003.

[67] Jörg König. Uptake transporters of the human oatp family. In Drug Transporters, pages 1-28. Springer, 2011.

[68] Gerd A Kullak-Ublick, Manfred G Ismair, Bruno Stieger, Lukas Landmann, Robert Huber, Flavia Pizzagalli, Karin Fattinger, Peter J Meier, and Bruno Hagenbuch. Organic anion-transporting polypeptide b (oatp-b) and its functional comparison with three other oatps of human liver. Gastroenterology, 120(2):525-533, 2001. 
[69] Oscar Briz, M Serrano, R MacIas, Javier Gonzalez-Gallego, and J Marin. Role of organic anion-transporting polypeptides, oatp-a, oatp-c and oatp8 , in the human placenta-maternal liver tandem excretory pathway for foetal bilirubin. Biochem. J, 371:897-905, 2003.

[70] Jörg König, Annick Seithel, Ulrike Gradhand, and Martin F Fromm. Pharmacogenomics of human oatp transporters. Naunyn-Schmiedeberg's archives of pharmacology, 372(6):432-443, 2006.

[71] E Link, S Parish, J Armitage, L Bowman, S Heath, F Matsuda, I Gut, M Lathrop, and R Collins. Slco1b1 variants and statin-induced myopathy-a genomewide study. The New England journal of medicine, 359 (8):789-799, 2008.

[72] Z. Yablonka-Reuveni. The skeletal muscle satellite cell: Still young and fascinating at 50. Journal of Histochemistry $\mathcal{E}$ Cytochemistry, 59(12): 1041-1059, Dec 2011. ISSN 1551-5044. doi: 10.1369/0022155411426780. URL http://dx.doi.org/10.1369/0022155411426780.

[73] Khurts Shilagardi, Shuo Li, Fengbao Luo, Faiz Marikar, Rui Duan, Peng Jin, Ji Hoon Kim, Katherine Murnen, and Elizabeth H Chen. Actinpropelled invasive membrane protrusions promote fusogenic protein engagement during cell-cell fusion. Science, 340(6130):359-363, 2013.

[74] Valerie Horsley and Grace K Pavlath. Forming a multinucleated cell: molecules that regulate myoblast fusion. Cells, tissues, organs, 176(1-3): 67-78, 2003.

[75] Richard Bischoff. Proliferation of muscle satellite cells on intact myofibers in culture. Developmental biology, 115(1):129-139, 1986.

[76] David Yaffe. Retention of differentiation potentialities during prolonged cultivation of myogenic cells. Proceedings of the National Academy of Sciences of the United States of America, 61(2):477, 1968.

[77] David Yaffe and ORA Saxel. Serial passaging and differentiation of myogenic cells isolated from dystrophic mouse muscle. Nature, (270):725-7, 1977.

[78] Ashley RP Hinson, Rosanne Jones, Lisa ES Crose, Brian C Belyea, Frederic G Barr, and Corinne M Linardic. Human rhabdomyosarcoma cell 
lines for rhabdomyosarcoma research: utility and pitfalls. Frontiers in oncology, 3, 2013.

[79] Robert M McAllister, John Melnyk, Jerry Z Finklestein, Ernest C Adams, and Murray B Gardner. Cultivation in vitro of cells derived from a human rhabdomyosarcoma. Cancer, 24(3):520-526, 1969.

[80] Alexander Treiber, Ralph Schneiter, Stephanie Häusler, and Bruno Stieger. Bosentan is a substrate of human oatp1b1 and oatp1b3: inhibition of hepatic uptake as the common mechanism of its interactions with cyclosporin a, rifampicin, and sildenafil. Drug metabolism and disposition, 35(8):1400$1407,2007$.

[81] Robert D Huber, Bo Gao, Marguerite-Anne Sidler Pfändler, Wenting Zhang-Fu, Simone Leuthold, Bruno Hagenbuch, Gerd Folkers, Peter J Meier, and Bruno Stieger. Characterization of two splice variants of human organic anion transporting polypeptide $3 \mathrm{a} 1$ isolated from human brain. American Journal of Physiology-Cell Physiology, 292(2):C795-C806, 2007.

[82] Francisco Noya, Wei-Ming Chien, Xiaoyun Wu, Nilam S Banerjee, John C Kappes, Thomas R Broker, and Louise T Chow. The promoter of the human proliferating cell nuclear antigen gene is not sufficient for cell cycledependent regulation in organotypic cultures of keratinocytes. Journal of Biological Chemistry, 277(19):17271-17280, 2002.

[83] Life Technologies. Trizolreagent. URL http://tools . lifetechnologies.com/content/sfs/manuals/trizol_reagent.pdf.

[84] D. P. Palermo, M. E. DeGraaf, K. R. Marotti, E. Rehberg, and L. E. Post. Production of analytical quantities of recombinant proteins in chinese hamster ovary cells using sodium butyrate to elevate gene expression. J Biotechnol, 19(1):35-47, Jun 1991.

[85] Carlos A Rabito and MV Karish. Polarized amino acid transport by an epithelial cell line of renal origin (llc-pk1). the apical systems. Journal of Biological Chemistry, 258(4):2543-2547, 1983.

[86] GP McStay, GS Salvesen, and DR Green. Overlapping cleavage motif selectivity of caspases: implications for analysis of apoptotic pathways. Cell Death \& Differentiation, 15(2):322-331, 2008. 
[87] I-K Wang, S-Y Lin-Shiau, and J-K Lin. Induction of apoptosis by apigenin and related flavonoids through cytochrome $\mathrm{c}$ release and activation of caspase-9 and caspase-3 in leukaemia hl-60 cells. European Journal of Cancer, 35(10):1517-1525, 1999.

[88] Susan Calvin, Jeff Emch Calvin, Jay Wang, Linda Jacobsen, and Simone Pitz. Fugene^ ${ }^{\circledR}$ hd transfection reagent: Choice of a transfection reagent with minimal off-target effect as analyzed by microarray transcriptional profiling. Nature Methods | Application Notes, 2006.

[89] Masaru Hirano, Kazuya Maeda, Yoshihisa Shitara, and Yuichi Sugiyama. Contribution of oatp2 (oatp1b1) and oatp8 (oatp1b3) to the hepatic uptake of pitavastatin in humans. Journal of Pharmacology and Experimental Therapeutics, 311(1):139-146, 2004.

[90] Kyuson Yun and Barbara Wold. Skeletal muscle determination and differentiation: story of a core regulatory network and its context. Current opinion in cell biology, 8(6):877-889, 1996.

[91] Norman W Carter, Floyd C Rector Jr, David S Campion, and Donald W Seldin. Measurement of intracellular ph of skeletal muscle with phsensitive glass microelectrodes. Journal of clinical investigation, 46(6):920, 1967.

[92] Markus Grube, Kathleen Köck, Stefan Oswald, Katrin Draber, Konrad Meissner, Lothar Eckel, Michael Böhm, Stephan B Felix, Silke Vogelgesang, Gabriele Jedlitschky, et al. Organic anion transporting polypeptide $2 \mathrm{~b} 1$ is a high-affinity transporter for atorvastatin and is expressed in the human heart*. Clinical Pharmacology \& Therapeutics, 80(6):607-620, 2006.

[93] Atsushi Suzuki, Shiki Okamoto, Suni Lee, Kumiko Saito, Tetsuya Shiuchi, and Yasuhiko Minokoshi. Leptin stimulates fatty acid oxidation and peroxisome proliferator-activated receptor $\alpha$ gene expression in mouse c2c12 myoblasts by changing the subcellular localization of the $\alpha 2$ form of ampactivated protein kinase. Molecular and cellular biology, 27(12):4317-4327, 2007. 
[94] Edward C Goodwin and FM Rottman. The 3'-flanking sequence of the bovine growth hormone gene contains novel elements required for efficient and accurate polyadenylation. Journal of Biological Chemistry, 267 (23):16330-16334, 1992.

[95] Manley TF Huang and Cornelia M Gorman. Intervening sequences increase efficiency of rna 3'processing and accumulation of cytoplasmic rna. Nucleic Acids Research, 18(4):937-947, 1990.

[96] Diana F Colgan and James L Manley. Mechanism and regulation of mrna polyadenylation. Genes \& development, 11(21):2755-2766, 1997.

[97] A Sachs and E Wahle. Poly (a) tail metabolism and function in eucaryotes. Journal of Biological Chemistry, 268:22955-22955, 1993.

[98] Tom De Bruyn, Sarinj Fattah, Bruno Stieger, Patrick Augustijns, and Pieter Annaert. Sodium fluorescein is a probe substrate for hepatic drug transport mediated by oatp1b1 and oatp1b3. Journal of pharmaceutical sciences, 100(11):5018-5030, 2011.

[99] Wilmar de Graaf, Stephanie Häusler, Michal Heger, Tessa M van Ginhoven, Gert van Cappellen, Roelof J Bennink, Gerd A Kullak-Ublick, Rolf Hesselmann, Thomas M van Gulik, and Bruno Stieger. Transporters involved in the hepatic uptake of $99 \mathrm{~m}$ tc-mebrofenin and indocyanine green. Journal of hepatology, 54(4):738-745, 2011.

[100] Siddharth Singh, Preet Paul Singh, Abha Goyal Singh, Mohammad Hassan Murad, and William Sanchez. Statins are associated with a reduced risk of hepatocellular cancer: a systematic review and meta-analysis. Gastroenterology, 144(2):323-332, 2013.

[101] Anantha Koteswararao Kanugula, Paradesi Naidu Gollavilli, Sathish Babu Vasamsetti, Santosh Karnewar, Raja Gopoju, Ramesh Ummanni, and Srigiridhar Kotamraju. Statin-induced inhibition of breast cancer proliferation and invasion involves attenuation of iron transport: intermediacy of nitric oxide and antioxidant defence mechanisms. FEBS Journal, 281(16):3719-3738, 2014.

[102] Paul M Ridker, Eleanor Danielson, FA Fonseca, Jacques Genest, Antonio M Gotto Jr, JJ Kastelein, Wolfgang Koenig, Peter Libby, Alberto J 
Lorenzatti, Jean G MacFadyen, et al. Rosuvastatin to prevent vascular events in men and women with elevated c-reactive protein. New England Journal of Medicine, 359(21):2195, 2008.

[103] Barbara A Masters, Marshall J Palmoski, Oliver P Flint, Richard E Gregg, David Wangiverson, and Stephen K Durham. In vitro myotoxicity of the 3-hydroxy-3-methylglutaryl coenzyme a reductase inhibitors, pravastatin, lovastatin, and simvastatin, using neonatal rat skeletal myocytes. Toxicology and applied pharmacology, 131(1):163-174, 1995.

[104] Peter J Mullen, Anja Zahno, Peter Lindinger, Swarna Maseneni, Andrea Felser, Stephan Krähenbühl, and Karin Brecht. Susceptibility to simvastatin-induced toxicity is partly determined by mitochondrial respiration and phosphorylation state of akt. Biochimica et Biophysica Acta (BBA)-Molecular Cell Research, 1813(12):2079-2087, 2011.

[105] Mai Itagaki, Akira Takaguri, Seiichiro Kano, Shigeru Kaneta, Kazuo Ichihara, and Kumi Satoh. Possible mechanisms underlying statin-induced skeletal muscle toxicity in 16 fibroblasts and in rats. Journal of pharmacological sciences, 109(1):94-101, 2009.

[106] Alan G Porter and Reiner U Jänicke. Emerging roles of caspase-3 in apoptosis. Cell death and differentiation, 6(2):99-104, 1999.

[107] Reiner U Jänicke, Michael L Sprengart, Mas R Wati, and Alan G Porter. Caspase- 3 is required for dna fragmentation and morphological changes associated with apoptosis. Journal of Biological Chemistry, 273(16):93579360, 1998.

[108] David J Graham, Judy A Staffa, Deborah Shatin, Susan E Andrade, Stephanie D Schech, Lois La Grenade, Jerry H Gurwitz, K Arnold Chan, Michael J Goodman, and Richard Platt. Incidence of hospitalized rhabdomyolysis in patients treated with lipid-lowering drugs. Jama, 292(21): 2585-2590, 2004.

[109] Simone Leuthold, Bruno Hagenbuch, Nilufar Mohebbi, Carsten A Wagner, Peter J Meier, and Bruno Stieger. Mechanisms of ph-gradient driven transport mediated by organic anion polypeptide transporters. American Journal of Physiology-Cell Physiology, 296(3):C570-C582, 2009. 
[110] Pablo Martinez-Becerra, Oscar Briz, Marta R Romero, Rocio IR Macias, Maria J Perez, Carlos Sancho-Mateo, Maria P Lostao, Jose M FernandezAbalos, and Jose JG Marin. Further characterization of the electrogenicity and ph sensitivity of the human organic anion-transporting polypeptides oatp1b1 and oatp1b3. Molecular pharmacology, 79(3):596-607, 2011.

[111] Masaki Kobayashi, Toshiki Kagawa, Rumi Takano, Shirou Itagaki, Takeshi Hirano, and Ken Iseki. Effect of medium ph on the cytotoxicity of hydrophilic statins. J Pharm Pharm Sci, 10:332-339, 2007.

[112] Takeda Pharamceuticals. Discontinuation of development of tak-475, 2008. URL http: //www.takeda.com/news/2008/20080328_3603.html.

[113] James D Bergstrom, Claude Dufresne, Gerald F Bills, Mary NallinOmstead, and Kevin Byrne. Discovery, biosynthesis, and mechanism of action of the zaragozic acids: potent inhibitors of squalene synthase. Annual Reviews in Microbiology, 49(1):607-639, 1995.

[114] Nigel S Watson and Panayiotis A Procopiou. 7 squalene synthase inhibitors: Their potential as hypocholesterolaemic agents. Progress in medicinal chemistry, 33:331-378, 1996.

[115] Claude Dufresne, Kenneth E Wilson, Sheo Bux Singh, Deborah L Zink, James D Bergstrom, Deborah Rew, Jon D Polishook, Maria Meinz, Leeyuan Huang, Keith C Silverman, et al. Zaragozic acids d and d2: potent inhibitors of squalene synthase and of ras farnesyl-protein transferase. Journal of natural products, 56(11):1923-1929, 1993.

[116] Masanori Ichikawa, Masami Ohtsuka, Hitoshi Ohki, Masahiro Ota, Noriyasu Haginoya, Masao Itoh, Yoshihiro Shibata, Kazuyuki Sugita, Yutaka Ishigai, Koji Terayama, et al. Discovery of df-461, a potent squalene synthase inhibitor. ACS medicinal chemistry letters, 4(10):932-936, 2013. 